\title{
THE RECOVERY OF PROTEIN FROM EGG YOLK PROTEIN EXTRACTION GRANULE BYPRODUCT
}

\author{
A Thesis \\ presented to \\ the Faculty of California Polytechnic State University, \\ San Luis Obispo \\ In Partial Fulfillment \\ of the Requirements for the Degree \\ Master of Science in Agriculture \\ with a Specialization in Dairy Products Technology
}

by

Irene J. Kaufman

May 2017 
(C) 2017

Irene J. Kaufman

ALL RIGHTS RESERVED 
TITLE:

AUTHOR:

DATE SUBMITTED:

COMMITTEE CHAIR:

COMMITTEE MEMBER:

COMMITTEE MEMBER:

COMMITTEE MEMBER:
The recovery of protein from egg yolk protein extraction granule byproduct

Irene J. Kaufman

May 2017

Vincent Yeung, Ph.D.

Assistant Professor of Dairy Science

Rafael Jimenez-Flores, Ph.D.

Professor of Dairy Science

Marie Yeung, Ph.D.

Associate Professor of Biological Sciences

Amy Lammert, Ph.D.

Associate Professor of Food Science and

Nutrition 


\begin{abstract}
The Recovery of Protein from Egg Yolk Protein Extraction Granule Byproduct
\end{abstract} Irene J. Kaufman

In addition to proving an excellent source of nutrients, eggs are used in the food, cosmetic, and biotechnology industries for their rheological and bioactive properties. Much of the potential for the added value is in individual components of the egg, rather than the whole egg. At low speed centrifugation, yolk separates into two distinct fractions - granules and plasma. It is becoming increasingly popular in the industry to remove the plasma fraction of the egg yolk to use for its livetins, particularly immunoglobulin Y, leaving behind a granule by-product ("yellow cake"). Previous research has shown potential added-value from the granule fraction, especially from its phosvitin and phospholipids. Granules are protein aggregates with complexes of phosvitin and high density lipoproteins linked by phosphocalcic bridges. In their native form, the proteins are mostly insoluble, however previous studies have shown the links can be broken by alterations in $\mathrm{pH}$, ionic strength, and mechanical treatments. This thesis project seeks to find potential uses for the egg yolk by product after the removal of the livetin fraction by means of further fractionation with mechanical treatment (filtration). Two variables were tested to extract more proteins from the yellow cake. Salt was added to $10 \%$ solids solution of yellow cake in water before filtration at four different $\mathrm{NaCl}$ levels: $0 \%, .05 \%, 1 \%$, and $2.5 \%$. Additionally $\mathrm{pH}$ was tested at four different levels: 4.6 , 4.8, 5.0, 5.2. The samples were also tested for antibacterial properties against Escherichia 
coli with a minimum inhibitory concentration assay (MIC). Analysis with BCA showed salt concentration had a significant effect on the yield of protein. The highest concentration of salt tested, $2.5 \%$, had the highest protein yield. Additionally, SDSPAGE showed $2.5 \%$ salt had the most unique protein bands. This could be to the disruption of the phosphocalcic links between the phosvitin and $\mathrm{HDL}$ by $\mathrm{NaCl}$, allowing the protein to solubilize. $\mathrm{pH}$ did not have a significant effect on the yield or types of proteins in the range tested in this experiment. There is no conclusive evidence of antibacterial properties against E. coli from the protein extract. The MIC assay had growth show up in all wells with the protein extract, however there was a visible decrease in turbidity with higher concentration of the protein extract. This could mean that the protein extract does have some antibacterial properties, but needs testing at higher concentrations or with isolated proteins/peptides. The SDS-PAGE revealed bands showing phosvitin present, which has known antibacterial properties. Overall, improvements to the methods for further protein extraction from egg yolk by-products will help lead the industry to finding novel uses and product applications. 


\section{ACKNOWLEDGMENTS}

I would like to thank my advisor, Dr. Rafael Jimenez-Flores, for his guidance and support, all the way from San Luis Obispo, CA to Indianapolis, IN to Columbus, $\mathrm{OH}$. Thank you to Dr. Vincent Yeung, Dr. Marie Yeung, and Dr. Amy Lammert for your advice, knowledge, and time.

I would also like to thank Dr. Jennifer VanderKelen for all of the support in the Baker lab. Thank you to Andrea Laubscher for the endless patience, advice and troubleshooting with me.

Thank you to Sean Vink, Paul Lyons, Matt Arnold, and Kristy Murray for always being available to answer a million questions, help with the processing and fix problems in the DPTC. Thank you to Ivan Filipi from Nestle Purina, for your insight on the initial extraction process.

Thank you to all of my fellow graduate students for the sense of community, support, friendship and advice. A special thank you to Marcela Morales, who helped with every step of the project that physically needed more than two hands, as well as bringing the most positive attitude to any and all work. Thank you to my friends back at home for the constant encouragement. 
Thank you to my parents and my sister for the endless love and patience throughout this process. Thank you to my step family and my in-laws for supporting me and always cheering me on. Lastly, thank you to my husband, Michael, for always believing in me. 
LIST OF TABLES __ xiii

LIST OF FIGURES __ xiv

LIST OF EQUATIONS ___ xvii

\section{CHAPTER}

CHAPTER 1: INTRODUCTION___ 1

CHAPTER 2: LITERATURE REVIEW __ 3

2.1 Egg Yolk Introduction __ 3

2.1.1 History _ 3

2.1.2 Nutritive value ___ 4

2.1.3 Beyond Nutrition __ 5

2.2 Structure and Composition _ 6

2.2.1 Whole Egg Structure __ 6

2.2.1.1 Shell and Shell Membrane ___ 7

2.2.1.2 Albumen and Ovum __ 7

2.2.2 Whole Egg Composition __ 8

2.2.3 Yolk Composition

2.2.3.1 Lipids _ 11

2.2.3.2 Proteins _ 13

2.2.4 Yolk Microstructure__ 15

2.2.4.1 Plasma__ 16

2.2.4.2 Granules —18 
2.3 Bioactive Proteins

2.3.1 Egg White Bioactive Proteins

2.3.1.1 Lysozyme 19

2.3.1.2 Ovalbumin 20

2.3.1.3 Ovotransferrin 21

2.3.2 Egg Yolk Bioactive Proteins 21

2.3.2.1 Lipoproteins 22

2.3.2.2 Phosvitin 23

2.3.2.3 Immunoglobulin Y 24

2.4 Effects of Processes on Structure and Functionality of Yolk Fractions 28

2.4.1 Salt 29

2.4.2 $\mathrm{pH}$ 30

2.4.3 Temperature (Freeze/Thaw) 31

2.5 Impact on Industry 32

2.5.1 Large Scale Protein Extractions 33

2.5.2 By Products 34

2.5.2.1 Enzymatic Proteolysis 34

2.5.2.2 Rheological Properties 35

2.6 Summary 36

CHAPTER 3: MATERIALS AND METHODS 39

3.1 Yellow Cake Collection and Standardization 39

3.1.1 Collection 39

3.1.2 Standardization 41 
3.2.1 Sample Preparation 42

3.2.2 Filtration 43

3.2.3 Sampling 46

3.2.4 Filtrate Storage 46

3.3 Precipitation 46

3.3.1 Sample preparation 46

3.3.2 Centrifugation 47

3.3.3 Acidification and incubation 48

3.3.4 Collection and storage 48

3.4 Protein Analysis 48

3.4.1 Protein quantification 48

3.4.1.1 Preparation 48

3.4.1.2 BCA 49

3.4.2 Protein characterization 50

3.4.2.1 Preparation 50

3.4.2.2 Gel Electrophoresis 51

3.5 Antibacterial Function of Bioactives 52

3.5.1 Bacteria and Broth Preparation 52

3.5.1.1 E. coli 52

3.5.1.2 Broth 52

3.5.2 Minimal Inhibitory Concentration (MIC) 53

3.5.2.1 Protein Standardization and Preparation 53 
3.5.2.2 Controls

3.5.2.3 Dilutions 54

3.5.2.4 Inoculation 54

3.6 Enzyme Digest 55

3.6.1 TrypZean Preparation 55

3.6.2 Proteolysis 55

3.7 Statistical Analysis 56

CHAPTER 4: RESULTS AND DISCUSSION 57

4.1 Sock Filtration 57

4.1.1 Protein Content 57

4.1.2 Protein Quantification 63

4.2 Precipitation 67

4.2.1 Observations of Addition of $\mathrm{NaCl}$ 67

4.2.2 Protein Content 70

4.3 MIC 72

4.3.1 No Proteolysis 72

4.3.2 Proteolysis No Endpoint 77

4.3.3 Proteolysis With Endpoints 82

CHAPTER 5: CONCLUSIONS AND LIMITATIONS 85

CHAPTER 6: DIRECTIONS FOR FUTURE RESEARCH 87

REFERENCES 88

\section{APPENDICES}

APPENDIX A: BCA Output 96 
APPENDIX B: BCA Raw Data Table

APPENDIX C: JMP Output for $\mathrm{NaCl}$ Study

APPENDIX D: JMP Output for $\mathrm{pH}$ Study 


\section{LIST OF TABLES}

Table

Page

2.1. Composition of Egg (adapted from USDA, 2000) 8

2.2. Major Albumen Proteins (adapted from awade, 1996)

2.3. Major Yolk Constituents (adapted from Mine, 2008) 10

2.4. Composition of yolk, granules, and plasma (g/100g dried matter) (adapted from Anton and Gandemer, 1997) 13

2.5. Properties of Yolk Proteins (adapted from Mine, 2008) 15

2.6. Properties of Egg White Proteins (adapted from Mine, 2008) 20

2.7. Egg Yolk IgY compared to mammalian IgG (adapted from Mine, 2008) 28

4.1 Averaged protein concentration from BCA after treatments 65 


\section{LIST OF FIGURES}

Figure $\quad$ Page

2.1. Structure of whole egg (Mine,2008) _ 6

2.2. Composition of Yolk (Anton, 2013) _ _ 11

2.3. Egg Yolk Structures (Anton, 2013) _ 16

2.4. LDL Structure (Anton, 2013) _ 16

2.5. LDL Adsorption (Anton, 2013) ___ 17

2.6. Production of antigen-specific IgY from laying hens for passive immunization via animal feed (Marcq, et al., 2013) __ 26

2.7. Effect of $\mathrm{NaCl}$ on protein solubility at $\mathrm{pH} 7$ (Anton and Gandemer, 1997) __ 30

2.8. Effect of $\mathrm{pH}$ and $\mathrm{NaCl}$ on protein solubility (Anton, 2013) ___ 31

3.1. Phase separation of egg yolks during IgY extraction. Water soluble layer is visible over lipid layers

3.2. Yellow cake solids in tank before removal (work of this thesis project) __ 40

3.3 Flow Diagram indicating the procedure to generate samples and treatments in this work _ 41

3.4. Experimental Design for Sock Filtration Experiment ___ 42

3.5 Sock Filtration Set up __ 44

3.6. Filter after running samples through

3.7. Filtrate samples collected after passing through filter system $\_$_ 45

3.8 Precipitation Design Flow___ 47

3.9. Example of MIC plate. Protein across rows is in $\mu \mathrm{g} / \mathrm{mL} \_55$ 
4.1. Trial 1 filtrate samples run on SDS-PAGE (4-20\% gel) visualized with Coomassie staining. Lane 1. Protein Standard; Lane 2. $0 \% \mathrm{NaCl}, \mathrm{pH}$ of 5.2; Lane 3. 0.5\% $\mathrm{NaCl}, \mathrm{pH}$ of 5.2; Lane 4. $1 \% \mathrm{NaCl}, \mathrm{pH}$ of 5.2; Lane 5. 2.5\% NaCl, pH 5.2; Lane 6. $0 \% \mathrm{NaCl}, \mathrm{pH}$ of 4.6; Lane 7. $0 \% \mathrm{NaCl}, \mathrm{pH}$ of 4.8 ; Lane 8. $0 \% \mathrm{NaCl}, \mathrm{pH}$ of 5.0. The molecular sizes of the marker are given in $\mathrm{kDa}$. 60

4.2. Trial 2 filtrate samples run on SDS-PAGE (4-20\% gel) visualized with Coomassie staining. Lane 1. Protein Standard; Lane 2. $0 \% \mathrm{NaCl}$, pH of 5.2; Lane 3. 0.5\% $\mathrm{NaCl}, \mathrm{pH}$ of 5.2; Lane 4. $1 \% \mathrm{NaCl}, \mathrm{pH}$ of 5.2; Lane 5. 2.5\% NaCl, pH 5.2; Lane 6. $0 \% \mathrm{NaCl}, \mathrm{pH}$ of 4.6; Lane 7. $0 \% \mathrm{NaCl}, \mathrm{pH}$ of 4.8 ; Lane $8.0 \% \mathrm{NaCl}, \mathrm{pH}$ of 5.0. The molecular sizes of the marker are given in $\mathrm{kDa}$.

4.3. Trial 3 filtrate samples run on SDS-PAGE (4-20\% gel) visualized with Coomassie staining. Lane 1. Protein Standard; Lane 2. $0 \% \mathrm{NaCl}, \mathrm{pH}$ of 5.2; Lane 3. 0.5\% $\mathrm{NaCl}, \mathrm{pH}$ of 5.2; Lane 4. $1 \% \mathrm{NaCl}, \mathrm{pH}$ of 5.2; Lane 5. 2.5\% NaCl, pH 5.2; Lane 6. $0 \% \mathrm{NaCl}, \mathrm{pH}$ of 4.6; Lane 7. $0 \% \mathrm{NaCl}, \mathrm{pH}$ of 4.8 ; Lane $8.0 \% \mathrm{NaCl}, \mathrm{pH}$ of 5.0. The molecular sizes of the marker are given in $\mathrm{kDa}$. 62

4.4. Sediment formed on bottom of centrifuged samples. From right to left: $\mathrm{pH}$ 5.2: $0 \% \mathrm{NaCl}, 0.5 \% \mathrm{NaCl}, 1 \% \mathrm{NaCl}, 2.5 \% \mathrm{NaCl} .0 \% \mathrm{NaCl}: \mathrm{pH}$ 4.6, $\mathrm{pH}$ 4.8. Pellicle formed c; on trial with $2.5 \% \mathrm{NaCl}$ 63

4.5. From right to left: $\mathrm{pH} 5.2: 0 \% \mathrm{NaCl}, 0.5 \% \mathrm{NaCl}, 1 \% \mathrm{NaCl}, 2.5 \% \mathrm{NaCl} .0 \% \mathrm{NaCl}$ : $\mathrm{pH}$ 4.6 Floating particles in tube with $1 \%$ salt 64

4.6. Effect of $\mathrm{NaCl}$ on protein concentration 66

4.7. Effect of $\mathrm{pH}$ on protein concentration 67 4.8. $3 \% \mathrm{NaCl}$ solution 68 
4.10. $5 \% \mathrm{NaCl}$ solution 68

4.11. $6 \% \mathrm{NaCl}$ solution 69

4.12. $7 \% \mathrm{NaCl}$ solution 69

4.13. Precipitation samples run on SDS-PAGE (4-20\% gel) visualized with Coomassie staining. Lane 1. Protein Standard; Lane 2. 3\% NaCl, room temperature (RT); Lane 3. 4\% NaCl, RT; Lane 4. 5\% NaCl, RT; Lane 5. 6\% NaCl, RT; Lane 6. 7\% $\mathrm{NaCl}, \mathrm{RT}$; Lane $7.4 \% \mathrm{NaCl}, 4^{\circ} \mathrm{C}$; Lane $8.5 \% \mathrm{NaCl}, 4^{\circ} \mathrm{C}$; Lane $9.6 \% \mathrm{NaCl}$, $4^{\circ} \mathrm{C}$; Lane $10.7 \% \mathrm{NaCl}, 4^{\circ} \mathrm{C}$. The molecular sizes of the marker are given in $\mathrm{kDa}$.

4.14. Trial 1 MIC with no proteolysis 74

4.15. Trial 2 MIC with no proteolysis 75

4.16. Trial 3 MIC with no proteolysis 76

4.17. Trial $1 \mathrm{MIC}$ with proteolysis with no endpoint 79

4.18. Trial 2 MIC with proteolysis with no endpoint 80

4.19. Trial 3 MIC with proteolysis with no endpoint 81

4.20. Trial 2 MIC with proteolysis with boiling as endpoint 83

4.21. Trial $2 \mathrm{MIC}$ with proteolysis heated to $50^{\circ} \mathrm{C}$ as endpoint 84 


\section{LIST OF EQUATIONS}

$\begin{array}{lll}\text { Equation } & \text { Page }\end{array}$

1. To calculate $5 \mathrm{~mL}$ of $10^{\wedge} 8 \mathrm{cfu} / \mathrm{mL}$ of $E$. coli 


\section{CHAPTER 1: INTRODUCTION}

Hen eggs have long been acknowledged as a good source of nutrition in the food industry. They provide an excellent source of essential protein, fat, vitamins and minerals. Eggs have also been touted for their use as an emulsifier in foods, as well as cosmetics. In more recent years, eggs are being recognized for their benefits beyond basic nutrition and emulsification. Eggs, and their components, are found to contain health benefits and bioactive properties (Anton et al., 2006). Some of these beneficial properties are found in individual components of the egg, rather than the whole egg.

While egg yolks are generally sold as whole, there is more potential added value in the applications of its fractions. At low speed centrifugation, yolk separates into two distinct fractions - granules and plasma. The plasma is comprised of low-density lipoproteins and livetin. Granules are composed of high-density lipoproteins, phosvitin, and low-density lipoproteins (Anton and Gandemer, 1997). It is becoming increasingly popular to remove livetin from the water-soluble fraction (plasma) of the egg yolk. The three types of livetin include $\alpha$-livetin, $\beta$-livetin, and $\gamma$-livetin (Mine, 2008). Of these, $\gamma$-livetin, referred to as $\operatorname{IgY}$, is of particular interest because of its potential immunotherapeutic and immunodiagnostic properties. IgY from egg is analogous to the mammalian immunoglobulin IgG, but has many benefits, including cost, and a reduction and refinement in animal use (Karlsson et al., 2004). As the use for egg yolk fractions expands, including commercial scale IgY extractions, there has been an increase in leftover yolk product after removal of livetin. Use of granules has not been as extensively studied, but has added- value potential, especially in its phospholipids and phosvitin. 
Granules are tightly compact in their structure, with complexes of phosvitin and HDL linked by phosphocalic bridges. Untreated, the proteins are largely insoluble, but can be broken by alterations in $\mathrm{pH}$, ionic strength, and mechanical treatments.

The purpose of this thesis is to look to recover and characterize the proteins leftover in the by-product of a large IgY extraction representative of many of the current models of extraction. Specifically, this thesis seeks to understand the effect of mechanical treatments, $\mathrm{pH}$, and $\mathrm{NaCl}$ concentration on protein recovery. Furthermore, it explores the potential anti-microbial activity of the recovered proteins. 


\section{CHAPTER 2: LITERATURE REVIEW}

\subsection{Egg Yolk Introduction}

\subsubsection{History}

Hens' eggs are important in the embryonic stage of development of the chick, serving as a source of energy and protection. The unique egg components designed for development are also what make them a good source of nutrition, functional activity, and biotechnological agents (Anton, 2006). Eggs have been consumed by humans for as long as we have existed. Birds and eggs predate humans, and evidence has found that wild fowl were domesticated since 3200 B.C. Descendants of chickens used for egg laying today are believed to have been brought to America with Columbus' ships in 1493. In the mid-late 1900's major improvements to sanitation and technology were made, shifting small family flocks to large commercial egg operations. Continued improvement in caging, automation, and hen health has since led to higher production, better hen health, uniform quality, and lower costs. (AEB, 2017). Since the 1960s, advances include efficient egg breaking machines, better technology in pasteurization, improved freezing methods, and better spray driers (Mine, 2008). The average laying hen produced 160 eggs in 1960, and from all the improvements has increased to an average of 325 eggs in 2009 (Purdue Agriculture: Food Animal Education Network, 2008).

With improved technology in processing eggs, there has been an increase in further processed egg products. Examples of egg products are hard boiled pre chopped eggs, omelets, quiches, precooked scrambled eggs, precooked egg patties, and scrambled 
egg mixes. Some processed egg products are used in the form of ingredients, including liquid whole egg yolk, whites, frozen yolk, and dried yolk or whites (Mine, 2008). Egg components are also being used in the cosmetic, medical, and nutraceutical industries (Anton, 2006).

The yolk of the chicken egg serves the biological function of sustaining the developing chicken embryo with lipids, proteins, vitamins and minerals, as well as preparing the first immune defense for the embryo. The aggregate of antibodies from the mother provide the embryo with this immunity (Mann, 2008). As well as its reproductive purposes, the yolk has uses in industry, including food, cosmetics, and biotechnology. The yolk provides a rich source of dietary lipids, proteins, vitamins and minerals (Anton, 2006) Yolk's unique properties make it a good food emulsifier, often used in the case of mayonnaises, salad dressings, and cream (Anton, 2013).

\subsubsection{Nutritive Value}

Eggs are known worldwide as an exceptional source of nutrition, especially providing a low cost, high quality source of protein. Whole egg protein holds the highest biological value, 94, of any of the major food protein sources (Mine, 2008). Though protein is found throughout the entire egg, most of it is found in the egg white (50\%) and egg yolk (40\%) with the remaining found in the shell and shell membranes.

(Abdou, 2013). Eggs contain all nine essential amino acids that humans require in our diets. Additionally, eggs are a good source of lipids, vitamins and minerals. The yolk contains vitamins $\mathrm{A}, \mathrm{D}, \mathrm{E}$ and $\mathrm{K}$, as well as a good source of iron and 
phosphorous. B1 and B12 are deposited in the albumen. The yolk and albumen both equally contain B2 and B9 (Anton, 2006). Song and Kerver (2000) found that the daily nutrient intake of people that consumed eggs was significantly higher than that of those who do not consume eggs. The study included fat (saturated and polyunsaturated), cholesterol, fiber, sodium, Vitamins E, A, C, B6, B12, and folate. They found all of these nutrients except fiber and B6 were higher in the egg consumers. Additionally, there was no association with high serum cholesterol concentrations (Song et al., 2016). Further, the food industry can fortify eggs with beneficial nutrients through the diet of the hen. Omega-3 fatty acids, lutein, and Vitamin E are commonly added to eggs to enhance nutrition (Mine, 2008).

\subsubsection{Beyond Nutrition}

Health benefits of food today are not solely assessed on their macronutrient and micronutrient content. Scientific research is finding that certain foods have physiologically active components that add value besides the established nutrients they contain; these foods are called functional foods. The International Food Information Council (IFIC) explains functional foods as "foods that provide health benefits beyond basic nutrition." These foods include whole foods, as well as fortified, enriched, or enhanced foods, and can possibly lead to the reduction of disease (ADA, 2004).

Eggs yolks are mostly made up of lipids (65\%) and consist of triglycerides, phospholipids (PL), cholesterol, and free fatty acids. The omega 3 fatty acids and 
phosphatidylcholine (PC) found in the yolk are of special interest due to their importance of in brain development and function, particularly for infants. PC and other phospholipids are being studied as a potential treatment for neurological disorders (Kullenberg, 2012). Egg yolk phospholipids have three times more PC than from natural soy phospholipids (Anton, 2006). Research in dietary PC has showed some evidence of cancer prevention. Suppression of nodule formation related to hepatic cancer and preneoplastic liver lesions were found in a study with PC supplementation in rats. It has also been found that the PLs could reduce the negative gastrointestinal side effects of non-steroidal anti inflammatory drugs when paired together (Kullenberg, 2012).

\subsection{Structure and Composition}

\subsubsection{Whole Egg Structure}

The main components of a hen's egg are the ovum (yolk), albumen (white), shell membranes, and shell. The shell consists of three layers; the outermost layer is the cuticle, then a calcium carbonate layer, and an innermost mammillary layer.

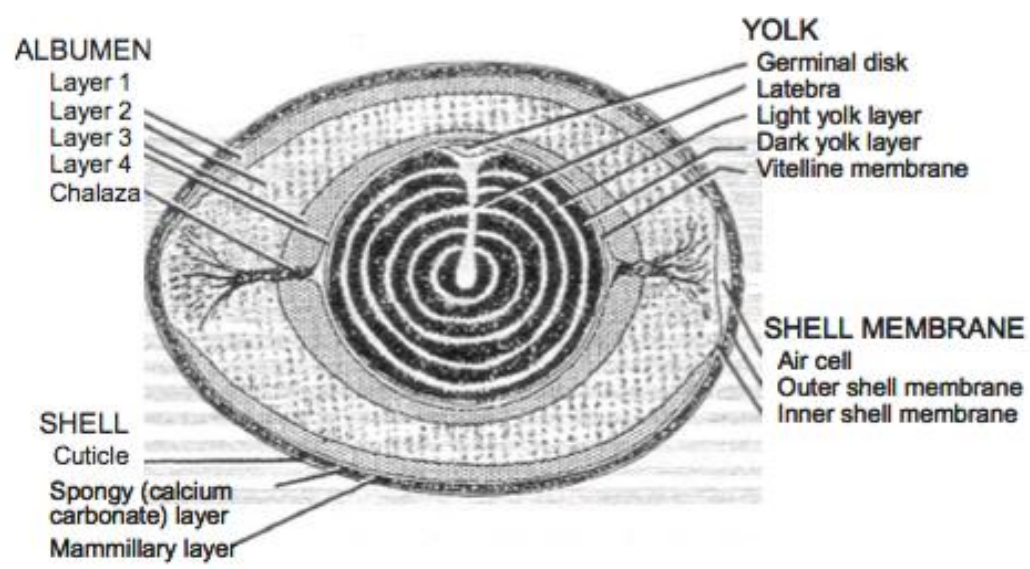

Figure 2.1 Structure of whole egg (Mine, 2008) 


\subsubsection{Shell and Shell Membrane}

The shell makes up 11\% of the egg (USDA, 2000). Eggshells' main purpose is to protect the egg against physical damage and microorganisms. (Mine, 2003) The shell membrane is just below the inner surface of the shell and encompasses the albumen. It consists of two membranes, inner and outer, that together are only $0.00609 \mathrm{~mm}$ thick. The inner membrane is made up of 3 layers of fibers that run parallel to the shell, while the outer membrane consists of 6 layers in different directions. The main purpose of the shell membrane is to contribute to the strength of the shell (Mine, 2008).

\subsubsection{Albumen and Ovum}

The albumen, often referred to as the egg white, is made up of four layers. Total it represents $\sim 58 \%$ of the egg. (USDA, 2000) Its main function is to deliver nutrients to the chick embryo during development. The albumen also serves to protect the yolk from harmful microorganisms (Abdou et al., 2013). There are two outer layers, one thick and one thin, and two inner layers. The outer thin layer next to the membrane is $\sim 23.3 \%$, followed by the outer thick white layer at $\sim 57.3 \%$. The thick layer is more viscous because of its high concentration of ovomucin. The inner thin layer that makes up $\sim 16.8 \%$ of the white, and innermost to the yolk is the calaziferous layer, 2.7\% (Mine, 2008). The chalaziferous layer, attached to the chalazae, encompasses the egg yolk. Although thin, it is a gelantinous strong layer that holds the yolk in place (USDA, 2000). 
The ovum, most often referred to as the yolk, consists of about $31 \%$ of the total weight an egg (USDA, 2000). It is composed of a three layer membrane called the vitelline membrane surrounding the yolk. Most of the yolk is made of yellow yolk, with only $2 \%$ white yolk (Mine, 2008). The more complex microstructure of the yolk will be covered in more detail.

\subsubsection{Whole Egg Composition}

The majority of the egg by weight is water, totaling $75 \%$. Proteins and lipids constitute the majority of the rest of the egg, along with small amounts of carbohydrates and minerals (Mine, 2008). While these are the main contribution to human nutrition, there are also other minute components that are being studied for their biological activities and functional properties.

Table 2.1 Composition of Egg (adapted from USDA, 2000)

\begin{tabular}{llllll} 
Whole & Percent & Water & Protein & Fat & Ash \\
egg & 100 & 65.5 & 11.8 & 11.0 & 11.7 \\
White & 58 & 88.0 & 11.0 & & \\
Yolk & 31 & 48.0 & 17.5 & 0.2 & 0.8 \\
& & $\begin{array}{l}\text { Calcium } \\
\text { carbonate }\end{array}$ & $\begin{array}{l}\text { Magnesium } \\
\text { carbonate }\end{array}$ & $\begin{array}{l}\text { Calcium } \\
\text { carbonate }\end{array}$ & $\begin{array}{l}\text { Organic } \\
\text { matter }\end{array}$ \\
Shell & 11 & 94.0 & 1.0 & 1.0 & 4.0 \\
\hline
\end{tabular}

By weight the shell is $\sim 94 \%$ calcite, with the remaining components mostly glycoprotein, proteoglycans, and minerals (Mine, 2003). The shell membranes are composed largely of $90 \%$ protein, with small amounts of ash and glucose. Water 
makes up most of the albumen, with proteins making up the highest amount of solids, about $10 \%$ of the total weight of the white. Glucose, lipids, and minerals are also present in smaller amounts (Mine, 2008). There are 40 different proteins in the albumen, the majority composed of ovalbumin. About half of the total protein found in eggs is found in the albumen, $40 \%$ in the yolk, with the remainder in the shell and shell matrix (Abdou, 2013). The yolk is 50\% solids. Lipids make up $~ 70 \%$ of the yolk (solid matter) and proteins $\sim 30 \%$ (Mine, 2008). Ovovitellin makes up the majority of the yolk protein. Of the lipid content, triglycerides make up $65.5 \%$, phospholipids $28.3 \%$, and cholesterol $5.2 \%$. The $\mathrm{pH}$ of the yolk when freshly laid is $\sim 6.0$, and after storage rises to $~ 7.0$ (USDA, 2000). The yolk is composed of plasma and granule fractions, which will be covered in more detail in following sections.

\section{Table 2.2 Major Albumen Proteins (Adapted from Awade, 1996)}

\begin{tabular}{ll|} 
Protein & Amount of total protein (\%) \\
Ovalbumin & 54 \\
Ovotransferrin & $12-13$ \\
Ovomuvoid & 11 \\
Lysozyme & $3.4-3.5$ \\
Ovomucin & $1.5-3.5$ \\
G2 ovoglobulin & 1.0 \\
G3 ovoglobulin & 1.0 \\
Ovoflavoprotein & 0.8 \\
Ovostatin & 0.5 \\
Cystatin & 0.05 \\
Avidin & 0.05 \\
\hline
\end{tabular}


Table 2.3 Major Yolk Constituents (Adapted from Mine, 2008)

\begin{tabular}{|c|c|c|}
\hline Constituent & Major Component & Relative \% \\
\hline \multirow[t]{10}{*}{ Proteins } & Apovitellenin I-VI & 37.3 \\
\hline & Lipovitellin apoproteins & \\
\hline & $\alpha$-Lipovitellin & 26.7 \\
\hline & $\beta$-Lipovitellin & 13.3 \\
\hline & Livetins & \\
\hline & $\alpha$-Livetin & 2.7 \\
\hline & $\beta$-Livetin & 4.0 \\
\hline & $\gamma$-Livetin & 2.7 \\
\hline & Phosvitin & 13.3 \\
\hline & Biotin binding protein & Trace \\
\hline \multirow[t]{6}{*}{ Lipids } & Triglyceride & 65 \\
\hline & Phosphatidylcholine & 26 \\
\hline & Phosphatidylethanolamine & 3.8 \\
\hline & Lysophosphatidylcholine & 0.6 \\
\hline & Cholesterol & 4 \\
\hline & Sphingomyelin & 0.6 \\
\hline
\end{tabular}

\subsubsection{Yolk Composition}

Composition of egg yolk can vary depending on the diet of the hen. Yolk mainly consists of proteins and lipids. Supplementation of various minerals or foods high in omega-3 fatty acids have been reported as changing the protein and lipid content, and have been used in industry to fortify the yolk for enhanced nutrition (Mine, 2008). The yellow pigment of the yolk, xanthophyll, comes from greens and corn in the hen's diet (USDA, 2000). Light centrifugation will separate the yolk into a plasma supernatant that makes about $77-81 \%$ of the yolk dry matter and a granule precipitate that makes up 19-23\% (Anton, 2013). Plasma is composed of 85\% low-density lipoproteins (LDL) and 15\% livetins. Granules are composed of 70\% high-density lipoproteins (HDL), 16\% phosvitin, and and 12\% LDL. (Anton, et al., 2000) As previously mentioned, numerous vitamins and minerals are present in the egg yolk. There is also a small amount of carbohydrate present in yolk, about $0.7-1.0 \%$, mostly 
bound as glycoproteins and glycolipids (Mine, 2008). Figure 2.2 breaks down the plasma and yolk components and their relative proportions.

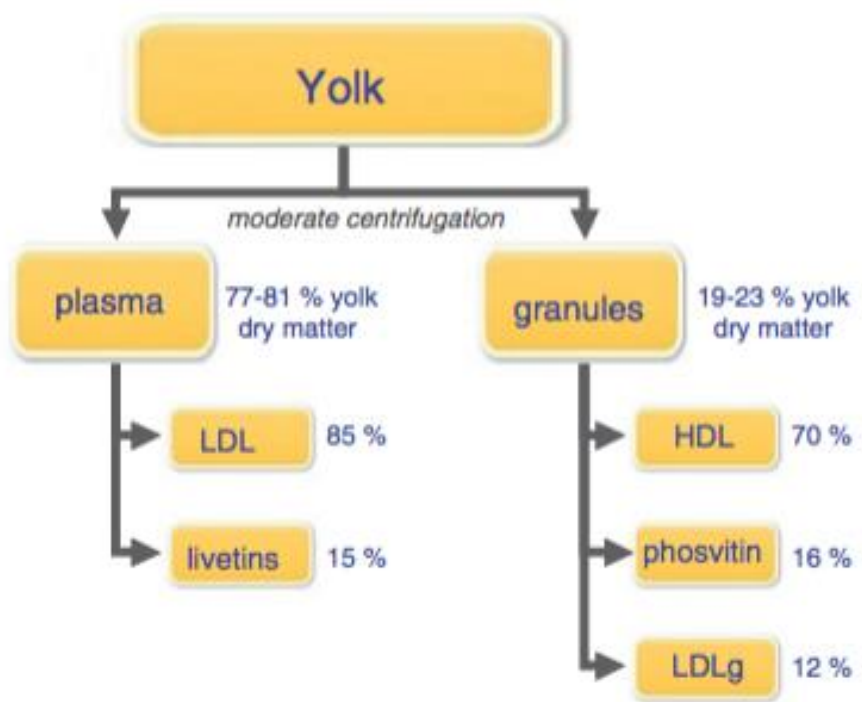

Figure 2.2 Composition of Yolk (Anton, 2013)

\subsubsection{Lipids}

Yolk lipid is made up of $~ 65 \%$ triglycerides, $28-30 \%$ phospholipid (PL), and $4-5 \%$ cholesterol. Composition of lipids can be affected by the hen's age, genotype, and diet (Mine, 2008). Research has suggested there are human health benefits to eggs fortified with PUFAS by means of the hen's diet. The essential fatty acid ratio in untreated egg yolk is about 9:1 n-6 PUFA to n-3 PUFA, while the healthy recommended proportion associated with reduced risk of cardiovascular disease is $5: 1$ (Marcet et al., 2014). A study by Milinsk et al. fed hens diets with different oils containing different amounts of fatty acids. They determined that the addition of oils into the diets were able to produce eggs with higher n-3 to n-6 ratio in the yolk lipids, while not affecting cholesterol content (2003). 
The lipids in yolk are a majority triacylglycerols, or triacylglycerides (TG). Saturated palmitic acids and stearic acids make up $\sim 30-38 \%$ of the fatty acids in yolk lipids, and monounsaturated and polyunsaturated fatty acids make up another $\sim 30 \%$ (Mine, 2008). A study by Brady et al., 2002 suggests that the TG released from the inner core of the lipoprotein is likely responsible for the antibacterial effect of egg yolk lipoprotein (Brady, 2002) Phosphatidylcholine (PC) and phosphatidylethanolamine (PE) are the major egg yolk PLs. Respectively, they make up $\sim 81 \%$ and $12 \%$ of egg yolk lecithin. Lysophosphatidylcholine (LPC), lysophosphatidylethanolamine (LPE), and sphingomyelins are also present in smaller amounts in yolk PL (Mine, 2008).

Sphingomyelins are only a minor constituent of yolk phospholipids. Although they only make up $2 \%$ of yolk lipids, they are important. Sphingomyelin may have chemoprotective properties, as well as therapeutic preventative uses (Barrenetxe et al., 2006). It also plays an important role in the cell membranes of mammalian tissues, particularly in the brain and nervous tissues, working to regulate cholesterol (Slotte et al., 2007). Cholesterol makes up $~ 1.6 \%$ of total egg yolk, and $\sim 5 \%$ of the egg yolk lipids (Mine, 2008). 
Table 2.4 Composition of yolk, granules and plasma (g/100g dried matter) (Adapted from Anton and Gandemer, 1997)

\begin{tabular}{|llll|}
\hline Constituent & Yolk & Granules & Plasma \\
Proteins & 33.2 & 63.8 & 24.6 \\
Lipids & 63.4 & 30.7 & 72.6 \\
Triglycerides (TG) & 43.2 & 19.6 & 51.7 \\
Phospholipids (PL) & 17.7 & 11.1 & 18.2 \\
Phosphatidylcholine (PC) & 15.7 & 10.0 & 16.0 \\
Phosphatidylethanolamine & 2.0 & 1.1 & 2.1 \\
(PE) & & & \\
Cholesterol & 2.6 & 1.3 & 2.7 \\
Lipids/Proteins & 1.9 & 0.5 & 3.0 \\
PL/TG & 0.41 & 0.61 & 0.35 \\
PC/PE & 7.5 & 9.1 & 7.6 \\
\hline
\end{tabular}

\subsubsection{Proteins}

LDL accounts for about two thirds of the yolk's total protein. It has a low density of .98 because its high lipid to protein content. It is responsible for much of the emulsifying functionality of egg yolk. LDL has at least two subfractions, called differing names such as LDL1 and LDL2, LDF1 and LDF2, and LDP1 and LDP2 (Mine, 2008). A study by Jolviet et al. (2006) showed there were nine major protein bands by SDS-PAGE. Two bands were a monomer and dimer of apovitellin I, and all other bands were associated with fragments of apolipoprotein B (2006).

HDL has a higher protein content of $80 \%$, to a lipid content of $20 \%$ (Mine, 2008).

The high protein content of HDL accounts for granules' density of $1.190 \mathrm{~g} / \mathrm{mL}$. (Strixner and Kulozik, 2013). HDL is composed of $\alpha$ - and $\beta$-lipovitellins, which vary in amino acid composition (Mine, 2008). HDL makes up about a sixth of the yolk 
solids in the granular fraction. It exists as a complex with phosvitin (Abdou et al., 2013).

Phosvitin is a phosphoglycoprotein with a high phosphorous content of $\sim 10 \%$. It is one of the most phosphorylated proteins in nature. Although it is insoluble in water in untreated conditions, with low ionic or acidic conditions, it can become soluble and has an ability to form a complex with metal ions (Abdou et al., 2013) Phosvitin is responsible for $60 \%$ of total egg yolk phosphoproteins and $\sim 90 \%$ of the phosphorous in yolk (Samaraweera et al., 2011).

Livetin makes up $30 \%$ of the plasma proteins. It is made of $\alpha$-livetin, $\beta$-livetin, and $\gamma$ livetins, which are analogous to the mammalian plasma proteins serum albumin, $\alpha 2$ glycoprotein, and $\gamma$-globulin, respectively (Mine, 2008). Most research has been done on the immunoglobulin IgY because of its promising uses. The $\gamma$-livetins, referred to as IgY, are the major antibodies found in hen's eggs. The IgY comes from the hen serum IgG, but has a different name to distinguish it from mammalian IgG (Mine, 2008). There are about $100-400 \mathrm{mg} \mathrm{IgY}$ in an egg, with 1.23 times more in the yolk than in the serum concentration (Abdou et al., 2013). 
Table 2.5 Properties of Yolk Proteins (Adapted from Mine, 2008)

\begin{tabular}{|c|c|c|c|c|}
\hline Protein & Percent & Localization & Molecular Weight & Characteristics \\
\hline $\begin{array}{l}\text { Low-density } \\
\text { lipoprotein } \\
\text { (LDL) }\end{array}$ & 65 & $\begin{array}{l}\text { Plasma and } \\
\text { granules }\end{array}$ & $\begin{array}{l}10,300 \mathrm{kDa} \\
\left(\mathrm{LDL}_{1}\right) \\
3,300 \mathrm{kDa} \\
\left(\mathrm{LDL}_{2}\right)\end{array}$ & $\begin{array}{l}\text { Lipid content } ~ 90 \% \\
\text { Apovitellenins I-VI known } \\
\text { as lipoproteins }\end{array}$ \\
\hline $\begin{array}{l}\text { Lipovitellin; } \\
\text { high-density } \\
\text { lipoprotein } \\
\text { (HDL) }\end{array}$ & 16 & Granules & $\begin{array}{l}400 \mathrm{kDa} \\
(\alpha, \beta- \\
\text { lipovitellin } \\
\text { complex) }\end{array}$ & Lipid content $\sim 25 \%$ \\
\hline Livetin & 10 & Plasma & $\begin{array}{l}80 \mathrm{kDa} \alpha \text {-livetin } \\
40,42 \mathrm{kDa} \\
\beta \text {-livetin } \\
180 \mathrm{kDa} \text {-livetin }\end{array}$ & $\begin{array}{l}\text { Serum albumin } \\
\text { Fragment of } C \text {-terminus } \\
\text { in vitellogenin } \\
\text { IgY (hen's serum IgG) }\end{array}$ \\
\hline Phosvitin & 4 & Granules & $33,45 \mathrm{kDa}$ & $\begin{array}{l}\text { Most phosphorylated } \\
\text { protein in nature }\end{array}$ \\
\hline $\begin{array}{l}\text { Egg yolk } \\
\text { riboflavin- } \\
\text { binding } \\
\text { protein (RBP) }\end{array}$ & 0.4 & Plasma & $36 \mathrm{kDa}$ & $\begin{array}{l}\text { Similar to flavoprotein in } \\
\text { egg white and to serum } \\
\text { RBP }\end{array}$ \\
\hline Others & 4.6 & Mainly plasma & & \\
\hline
\end{tabular}

\subsubsection{Yolk Microstructure}

Egg Yolk is composed of non-soluble protein aggregates dispersed in a clear solution of soluble proteins and low-density lipoproteins. The non-soluble aggregates are called granules, and the soluble solution is called plasma. Centrifugation can easily separate the yolk into these two fractions (Anton, 2013). Plasma and granules exhibit different functionality, due to their differing compositions and structures. 


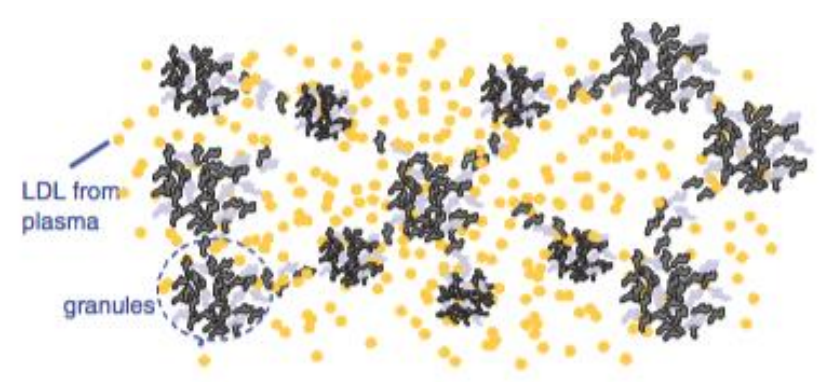

Figure 2.3 Egg Yolk Structures (Anton, 2013)

\subsubsection{Plasma}

Plasma consists mainly of LDL and livetins, and is known to be soluble in its native form. Plasma is known as a useful emulsifying agent. The emulsifying properties of plasma behave similarly to yolk, while granules behave differently. This suggests that the plasma fraction is responsible for the yolk's emulsifying capability. Specifically, the LDL has been attributed with the excellent emulsifying properties (Jolviet et al., 2006).

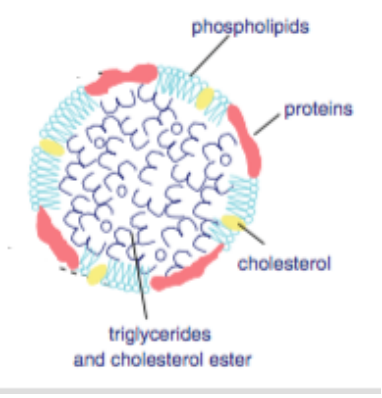

Figure 2.4 LDL Structure (Anton, 2013)

LDL are spherical nanoparticles that range from $17 \mathrm{~nm}$ to $60 \mathrm{~nm}$ in diameter. They have a lipid core made of triglycerides and cholesterol esters surrounded by a monofilm of phospholipids and proteins. LDL proteins are non-soluble in water or aqueous buffer, making direct adsorption difficult, shown in Figure 2.5. The 
nanostructure of the LDL is what allows the transport through the aqueous phase in a soluble form to the interface to then be released (Anton, 2013). Jolviet et al. (2006) identified two apoproteins from purified LDL_Apovitellenin I and Hen Apolipoprotein B (2006). Their study suggests that it is the apoproteins that serve as the initial anchorage at the interface, then initiate disruption of the structure and denaturation of the protein, leading to the spread of LDL at the interface.

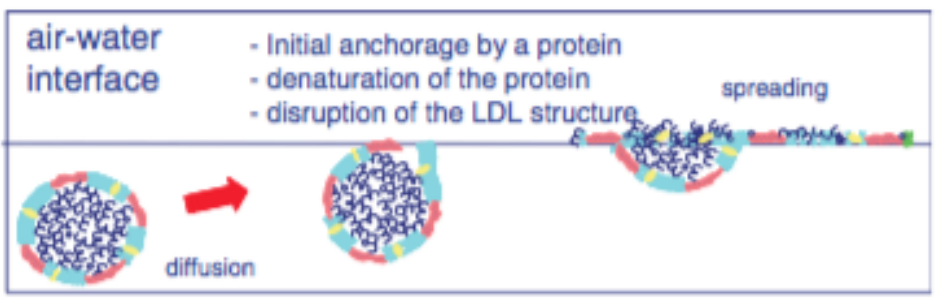

Figure 2.5 LDL Adsorption (Anton, 2013)

Livetin is a water-soluble, non-lipid, globular glycoprotein. Immunologically it is analogous to mammalian protein plasma (Abdou et al., 2013). The structure of IgY and mammalian IgG are similar; both have two heavy chains and two light chains, but also come with differences. The molecular mass of IgG is $150 \mathrm{kDa}$, and $180 \mathrm{kDa}$ for $\operatorname{IgY}$. It has been proposed that $\mathrm{IgY}$ is more hydrophobic than $\mathrm{IgG}$, favorable to the high lipid environment in egg yolk. The different amino acid sequences and structure cause different functionality in the immunoglobulins (Karlsson et al., 2004).

Research has shown that IgY is accompanied by a polypeptide complex called yolkin. Yolkin is an immunostimulatory heterogeneous set of proteins that range in size from 1-35 kDa (Zablocka et al., 2014). 


\subsubsection{Granules}

Granules are made up of protein aggregates ranging from $0.3 \mu \mathrm{m}$ to $2 \mu \mathrm{m}$ in diameter. Granules are mainly insoluble in their native form, as the HDL and phosvitin form complexes linked by phosphocalcic bridges (Anton, 2013). The HDL and phosvitin both have high amounts of phosphoserin amino acids that are able to bind calcium. These phosphocalcic bridges make the structure of the granule compact, poorly hydrated, and weakly accessible to enzymes. This leads to an efficient protection against thermal denaturation and heat gelation. The heat stability attributes of the granule fraction makes them a better choice for emulsion stabilization over plasma or yolk (Sirvente et al., 2007). Phosphopeptides have a molecular structure that allow that usually contain clusters of phosphoserines, which is responsible for binding calcium and inhibiting the formation of insoluble calcium phosphates. The phosvitin in egg yolk is of particular interest because a molecule of it has $\sim 120$ phosphoserine residues, as opposed to a casein subunit with only 1-13 residues. This could produce calcium binding and releasing capabilities (Samaraweera et al., 2011).

\subsection{Bioactive Proteins}

Many foods contain proteins that have reported biological activities. Such activities include antimicrobial, anti hypertensive, anti oxidative, vitamin and mineral binding, immunoregulatory and immunosuppressing, and enzyme inhibitory properties. Often it is the peptides released during food fermentation or from enzymatic proteolysis during digestion that possess the biological activities (Walther and Sieber, 2011). Eggs are a valuable source of such proteins and peptides with biological properties. 
These active molecules potentially provide use in the medical, pharmaceutical, cosmetic, nutraceutical and biotechnological industries (Anton et al., 2006). The use of peptides and proteins with antimicrobial activity is of particular significance to medicine, pharmacology, and the food industry because of recent microbial resistance to antibiotics. Such proteins and peptides are able to inhibit or attack pathogenic microorganisms, but leave the host cells unharmed. Greater insight on antimicrobial peptides could help a better understanding of the resistance mechanisms in bacteria and a potential replacement of antibiotics as a therapeutic agent against pathogenic diseases (Coutinho et al., 2007).

While egg white bioactive proteins and peptides have been more extensively researched and used in the food industry, yolk proteins are currently less described. Though many components of the egg white contain biological activity, this section will briefly describe a few of the most abundant and used bioactive protein applications in the egg white, but this thesis will focus on the utilization of the bioactive proteins and peptides in the yolk portion.

\subsubsection{Egg White Bioactive Proteins}

\subsubsection{Lysozyme}

Lysozyme is a widely used enzyme across the world in the foods and pharmacological industries. It is used to preserve fresh produce and meats by coating the surfaces, added to cheeses to control undesirable bacteria, and added to some wines to replace $\mathrm{SO}_{2}$ to inhibit malolactic fermentation. More than 100 tons of 
lysozyme are used annually (Mine et al., 2004). The antimicrobial activity of lysozyme is effective against Gram-positive bacteria. It breaks down peptidoglycan, the structural component of Gram-positive bacterial cell walls, by splitting its $\beta-(1,4)$ linkages between $\mathrm{N}$-acetylmuramic acid and $\mathrm{N}$-acetylglucosamine (Xu et al., 2007). Although lysozyme is commonly found in nature, including humans' secretions and tissues, hens eggs are a richer and easily available source of the enzyme (Abdou et al., 2013).

\begin{tabular}{|c|c|c|c|}
\hline Protein & $\begin{array}{l}\text { Proportion of } \\
\text { Albumen (\%) }\end{array}$ & $\begin{array}{l}\text { Molecular } \\
\text { Weight (kDa) }\end{array}$ & Characteristics \\
\hline Ovalbumin & 54 & 45 & $\begin{array}{l}\text { Enzyme inhibitor; } \\
\text { binds } \mathrm{Fe}, \mathrm{Mn}, \mathrm{Cu}\end{array}$ \\
\hline Ovotransferrin & 12 & 76 & Binds metallic ions \\
\hline Ovomucoid & 11 & 28 & Inhibits trypsin \\
\hline Ovomucin & 3.5 & 110 & $\begin{array}{l}\text { Inhibits viral } \\
\text { Hemagglutination }\end{array}$ \\
\hline Lysozyme & 3.4 & 14.3 & Lyses some bacteria \\
\hline Ovoglobulin G2 & 1 & $33-49$ & Good foaming agent \\
\hline Ovoglobulin G3 & 1 & $33-49$ & Good foaming agent \\
\hline Ovoinhibitor & 1.5 & 49 & $\begin{array}{l}\text { Inhibits serine } \\
\text { proteases }\end{array}$ \\
\hline Cystatin & 0.05 & 12.7 & $\begin{array}{l}\text { Inhibits } \\
\text { thioproteases }\end{array}$ \\
\hline Ovoglycoprotein & 1.0 & 24.4 & Sialoprotein \\
\hline Ovoflavoprotein & 0.8 & 32 & Binds riboflavin \\
\hline Ovomacroglobulin & 0.5 & $760-790$ & Strongly antigenic \\
\hline Avidin & 0.05 & 68.3 & Binds biotin \\
\hline Other proteins & 4.2 & & \\
\hline
\end{tabular}

\subsubsection{Ovalbumin}

Ovalbumin is often used as a reference protein in biochemistry as a carrier, stabilizer, blocking agent, and standard (Abdou et al., 2013). Two peptides, ovokinin and ovikin 
(2-7) are derivatives of ovalbumin that have been associated with preventing

hypertension. Ovokinin is obtained via peptic digest of ovalbumin, and ovokinin (2-7) is obtained from chymotryptic digest of ovalbumin (Anton et al., 2006). Research has also has shown antioxidant, anticancer, and antimicrobial properties (Mine 2008).

\subsubsection{Ovotransferrin}

Ovotransferrin is an iron-binding protein. It can be used as a nutritional supplement in products like protein supplements, iron supplements, and other iron fortified foods and beverages (Abdou et al., 2013). While lysozyme is effective at inhibiting Grampostitive bacteria, ovotransferrin can inhibit Gram-negative bacteria by depriving the bacteria of iron, which is essential to its growth (Anton et al., 2006).

\subsubsection{Egg Yolk Bioactive Proteins}

The egg yolk contains bioactive components mostly in the form of proteins (17\% of yolk) and lipids (34\%). The most researched physiological functions of the egg yolk are their antibacterial, antiviral, anticancer, antioxidant, anti-inflammatory, and immunological properties (Mine, 2008). The lipoproteins, phosvitin, and livetins are the main bioactive proteins, as well as precursors to bioactive peptides, in the yolk. The hen's liver synthesizes the egg yolk protein, secretes it into the blood stream, transfers it to the ovary, and then finally to the oocyte to accumulate yolk (Mine, 2008). Often it is the case that the bioactive peptides within the protein are inactive in its native form, and released upon proteolysis during digestion or processing 
(Samaraweera et al., 2011). It is worth noting that the lipid portion of the egg yolk contains many bioactives, although will not be mentioned in detail this review.

\subsubsection{Lipoproteins}

Although LDL is commonly known for its emulsifying abilities, it also has bioactive properties. One study by Shinohara et al. (1993) looked at the effects of lipoproteins on the growth and production of IgM in a human-human hybridoma cell. The LDL portion was shown to promote the production of the IgM (Abdou et al., 2013). Egg yolk has also been used to preserve mammalian spermatozoa against cold shock in frozen semen stored for artificial insemination. It has been suggested that the LDL is responsible for the resistance against cold shock, as well as improved motility after storage. The mechanism proposed for this property could be that the LDL adheres to cell membranes during the freeze-thawing, protecting the spermatozoa membranes (Anton et al., 2006). While there is not extensive research on this cryoprotective property, it could be useful beyond sperm preservation.

The HDL portion of egg yolk is important for antimicrobial activity. Kassaify and Mine (2004) studied the effect of non-immunized egg yolk powder on the pathogens S. enteritidis, S. typhimurium, and E. coli $\mathrm{O} 157: \mathrm{H} 7$ when included in the hens' feed. At powder concentrations between 5-10\%, colonization of all mentioned pathogens were either eliminated or reduced in the intestines, as well as elimination or reduction in the internal organs. The results showed inhibited colonization, as well as invasion, implying anti-adhesive properties of egg yolk. A later study by Kassaify et al. in 
2005 announced that this anti-adhesive effect is associated with the HDL and their peptides (Mine and Kovacs-Nolan, 2006).

The lipoproteins in egg yolk are important protein precursors to biologically active peptides. When vitellenin, an apoprotein of yolk lipovitellenin (LDL), is digested with pronase, it forms glycopeptides A and B. Glycoprotein A has a high content in sialic acid, a carbohydrate known for blood protein half-life regulation, toxin neutralization, regulation of cellular adhesion, and inhibition of cell cytosis. It is proposed that these peptides could be used as carriers of sialic acid, aiding in its adsorption and bioavailability (Zambrowicz, et al., 2014).

\subsubsection{Phosvitin}

Due to its structure, phosvitin has a high ability to chelate metals, particularly calcium, magnesium, and iron. The majority of iron present in the yolk is bound to phosvitin. Even under thermal stress, phosvitin maintains its high ability to bind iron when compared to other phosphoproteins (Samaraweera et al., 2011) Xu et al. (2007) found that phosvitin also has a higher ability to bind iron that its phosphopeptide derivatives. This metal binding capacity is partly responsible for certain bioactive traits, including antibacterial and anti-oxidative, as well as its emulsifying properties. Research has shown antibacterial activity against $E$. coli under thermal stress, as it disrupts the cells and DNA of the bacteria. This effect is caused by a combination of the metal-chelating abilty and high surface activity (Mine and Kovacs-Nolan, 2006). Though the phosphopeptides from phosvitin exhibit higher antioxidant properties, the 
phosvitin itself also shows to have antioxidant activity. In a phospholipid emulsion

system with $\mathrm{Fe}^{2+}, \mathrm{Cu}^{2+}$, and hemin, the phosvitin successfully inhibited $\mathrm{Fe}^{2+}$ and $\mathrm{Cu}^{2+}$ mediated oxidation of lipids, though not effective against hemin-mediated phospholipids oxidation. This antioxidant activity went down after autoclaving, however was maintained at pasteurization temperatures (Samaraweera et al., 2011).

Phosphopeptides from milk caseins are used in industry for their antioxidant, mineral-binding, and anti-microbial effects. Egg yolk phosvitin has not yet received as much attention for the production of phosphopeptides. Egg yolk phosvitin is the most phosphorylated protein in nature and could be a better source of phosphopeptides but could because it contains more phosphates in the molecule than casein (Samaraweera et al., 2011). A study by Xu et al. (2007) examined antioxidant activity and iron binding capability of tryptic digests of hen egg yolk phosvitin. They found that phosvitin, and phosvitin oligophosphopeptides (PPP) both inhibited linoleic acid oxidation, however the PPP were significantly more effective, even at a lower concentration than the phosvitin. Since PPP's only contain 35\% the amount of phosphorous compared to phosvitin, they concluded that the ability of PPP to inhibit linoleic acid oxidation is not solely from its metal ion-binding capability. PPPs antioxidant effect could also be from the amino acid composition and/or sequence.

\subsubsection{Immunoglobulin Y}

Immunoglobulin $\mathrm{Y}$ technologies have been increasingly gaining attention for all of their potential applications, including disease prevention in humans, medical 
diagnoses, and an alternative to antibiotics in animal feed. There are many advantages to using immunoglobulin Y (IgY) from hen's egg yolk over traditionally used mammalian IgG. There are benefits to animal welfare, cost effectiveness, and no problematic interactions. Antibiotics are used in the livestock industry for growth and disease prevention for over 50 years. However, in recent years, the industry has been under pressure to find an alternative because of the growing rate of antibiotic resistance in animals and humans. The E.U. banned antibiotics for growth production in 2006, and the U.S. FDA started phasing out non-medical antibiotic use in livestock at the end of 2013 (Li et al., 2015).

IgY passive immunization therapy could be an effective alternative to antibiotics. In passive immunity, the antibodies produced from one individual are transferred to another, like in the case of a mother to her newborn via the placenta or a hen to her egg. In contrast, active immunization is where the animal has to produce its own antibodies, after acquiring a disease or receiving a vaccination. (CDC, 2017) Because hens transfer their antibodies to their chick in the yolk, immunizing the hen will produce eggs composed of the specific antibodies. This could easily be done orally as a feed additive, usually as a freeze- or spray-dried powder (Marcq et al., 2013). 


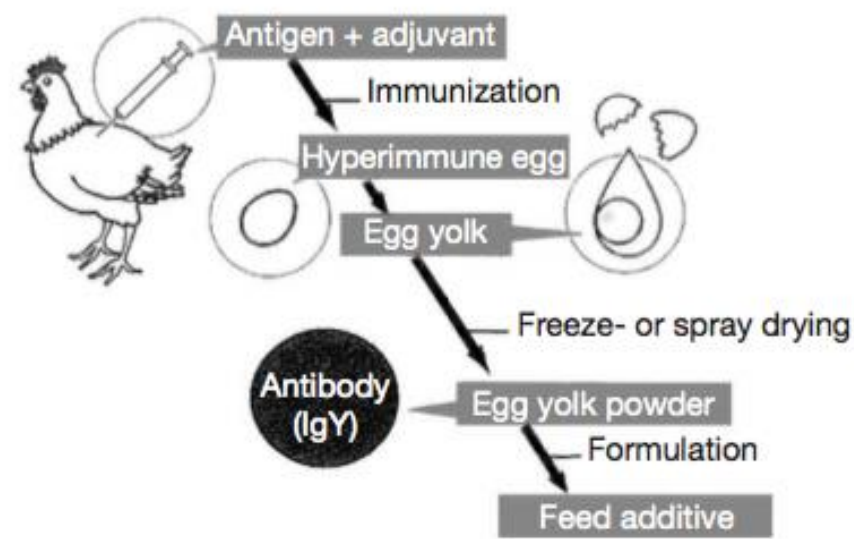

Figure 2.6 Production of antigen-specific IgY from laying hens for passive immunization via animal feed (Marcq, et al., 2013)

Oral administration of $\operatorname{IgY}$ has shown it could be a valuable treatment for numerous enteric infections, including rotaviruses, enterotoxigenic E. coli, Salmonella, and $H$. pylori. Studies with oral treatment of pathogen specific IgY have been successful in treating rotavirus, E. coli and Salmonella in studies done on animals (Karlsson et al., 2004).

Antibodies specific to certain pathogens can effectively be orally administered to humans to build protective immunity. Unless someone has an allergy to eggs, IgY from eggs can be given orally with virtually no risk of side effects because eggs are a normal dietary ingredient (Anton et al., 2006). Heliobacter. pylori is a pathogen that resides in the gastric and duodenal muscosa that causes gastritis and ulcers and infects over half the population worldwide. Antibiotics are usually administered to patients with H. pylori, but are sometimes ineffective or have adverse side effects. When $H$. pylori colonizes in the gastric mucosa, it produces urease enzyme to degrade urea into ammonia. $H$. pylori uses the ammonia to neutralize the microenvironment in gastric 
muscosa. Subsequently, urease specific IgY has ben created, and has proved to work to suppress the H. pylori colonization. In Japan yogurt fortified with IgY urease made from egg yolk was developed to decrease H. pylori. Clinical studies in Japan, Korea, and Taiwan all showed significant results in a decrease in the bacteria in volunteers who ate the yogurt twice daily for 12 weeks (Anton et al., 2006).

Although specific antibodies have been prepared and collected from the blood serum of small mammals such as rabbits, goats, and guinea pigs, there are many advantages to using chicken IgY as an alternative. It is a far less invasive procedure to procure IgY from eggs than it is to procure IgG from mammals. For eggs, the chicken is vaccinated and the eggs collected. The yolk and white are separated, and the $\operatorname{IgY}$ is extracted from the yolk from a choice of extraction processes. It is a much more invasive procedure to extract IgG from mammalian serum because the animals must be bled to obtain the antibodies. Also, the egg yolk only has IgY to begin with, while mammalian serum additionally has $\operatorname{IgA}$ and $\operatorname{IgM}$ that need to be separated out (Mine, 2008). In addition to animal welfare, egg yolk is a more cost effective source than mammals. One hen can produce the same amount of antibodies in a year that would take 4.3 rabbits to produce. The cost is also lower to maintain laying hens than mammals (Li et al., 2015). Functionally, chicken IgY is advantageous to use in humans over mammalian serum IgG because there is no cross reactivity between chicken IgY and mammalian IgG. Mammalian IgG activates with Fc and complement receptors, which is not a problem with chicken $\operatorname{IgY}$. Not only does this make IgY a better choice for immune responsiveness in humans, but also reduces interference 
problems when used in immunological assays (Karlsson et al., 2004). Another study by Nilsson et al. (2012) looked at the stability of IgY stored at room temperature, above $4^{\circ} \mathrm{C}$. Over a six month period, they found no reduction in antibody activity. This means that eggs could potentially stored for at least six months at room temperature without decline in antibodies, allowing increased batch sizes in production.

Table 2.7 Egg yolk IgY compared to mammalian IgG (Adapted from Mine, 2008)

\begin{tabular}{|c|c|}
\hline Egg Yolk IgY & Mammalian IgG \\
\hline Molecular weight of $\sim 180,000 \mathrm{kDa}$ & Molecular weight of $\sim 150,000$ \\
\hline H-chain region contains 4 domains & $\begin{array}{l}\text { H-chain region contains } 4 \\
\text { domains }\end{array}$ \\
\hline Isoelectric point $=\sim 6.0$ & Isoelectric point $=\sim 7.0$ \\
\hline Thermal denaturation $=73.9^{\circ} \mathrm{C}$ & Thermal denaturation $=77.0^{\circ} \mathrm{C}$ \\
\hline \multicolumn{2}{|l|}{ Does not activate complement of mammals } \\
\hline \multicolumn{2}{|l|}{$\begin{array}{l}\text { Does not combine with proteins } A \text { and } G \\
\text { (IgG binding proteins) }\end{array}$} \\
\hline \multicolumn{2}{|l|}{ Does not combine with a rheumatic factor } \\
\hline $\begin{array}{l}\text { Does not combine with Fc receptor of mammalian } \\
\text { a cell }\end{array}$ & \\
\hline
\end{tabular}

\subsection{Effects of processes on structure and functionality of yolk fractions}

When egg yolk is fractionated, the plasma and granules behave differently than the native yolk. By using the fractions, as opposed to the whole yolk, there is more of an opportunity to maximize the functionalities of the yolk, as well as by products that are 
produced from processes like protein extractions. The microstructure of the egg is what gives it much of its functionality, and can be exploited by different treatments. Modifications of the $\mathrm{pH}$, ionic conditions, and presence of mineral cations all closely effect the structure and function (Causeret et al., 1991).

\subsubsection{Salt}

Ionic strength greatly affects the solubility of the granule fraction, but not the plasma. At ionic strength below $0.1 \mathrm{M} \mathrm{NaCl}$, complete yolk is $25 \%$ solubilized. For plasma, it is about $80 \%$ solubilized, and granules only $10 \%$. The solubility for the yolk and granules rose to $\sim 80 \%$ with an increase to $0.3 \mathrm{M} \mathrm{NaCl}$, while the plasma remained at $80 \%$ solubility. When raised to $0.5 \mathrm{M} \mathrm{NaCl}$, these values remained the same (Anton and Gandemer, 1997). The granules reach complete disruption at $1.71 \mathrm{M} \mathrm{NaCl}$, releasing the HDL and phosvitin from their complexes. The solubility increase with addition of $\mathrm{NaCl}$ is because phosvitin is a soluble protein at low levels of salt, and HDL behaves like soluble proteins (Anton, 2013). The reason for low solubility of granules below $0.3 \mathrm{M} \mathrm{NaCl}$, is due to the structure; specifically the HDL-phosvitin complexes. When $\mathrm{NaCl}$ is increased to above $0.3 \mathrm{M}$, the phosphocalcic bridges linking HDL and phosvitin are disrupted by monovalent sodium (Anton and Gandemer, 1997). Emulsions made with yolk, plasma and granules all showed no difference at $0.5 \mathrm{M} \mathrm{NaCl}$, however, in distilled water the granules have a lower emulsifying activity than plasma. It is suggested that the granules have a similar emulsifying capability at $0.3 \mathrm{M} \mathrm{NaCl}$ that plasma has in its native form (Strixner and Kulozik, 2013). 


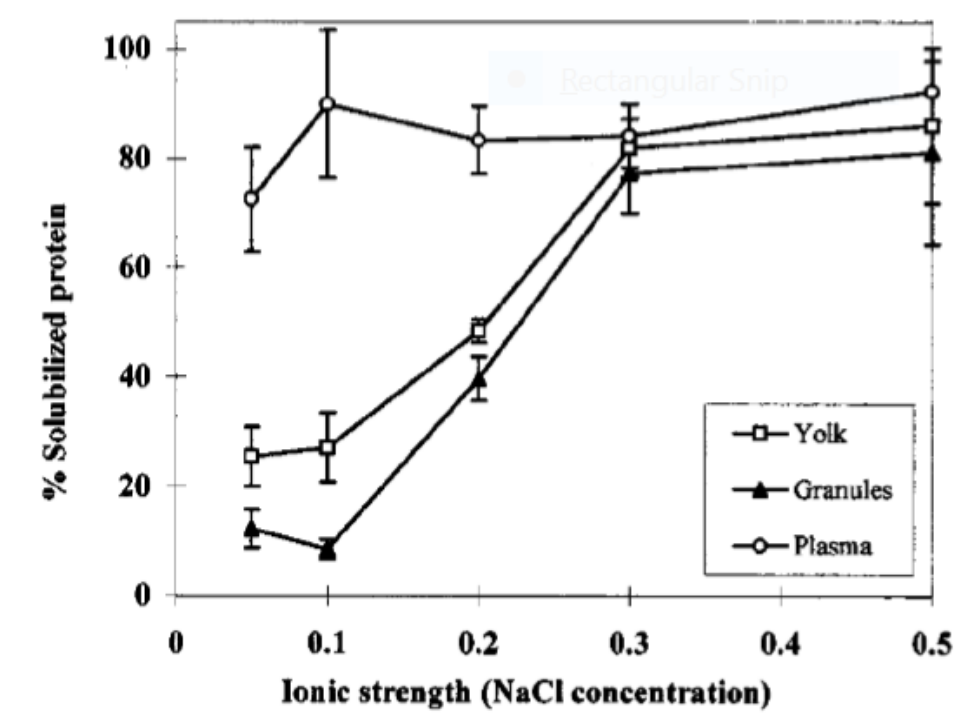

Figure 2.7 Effect of $\mathrm{NaCl}$ on protein solubility at pH 7 (Anton and Gandemer, 1997)

\subsection{2 pH}

Previous findings about the $\mathrm{pH}$ of the granule fraction has shown a mixed relationship with functionality of the product. Causeret (1991) observed that when the original $\mathrm{pH}$, in the case of the study 6.3, that both an increase and decrease in $\mathrm{pH}$ could disrupt the granules. At a pH less than 4.2 or above 6.3 , the solubility and viscosity of the mixture increased. The acidification or alkalization both break up the phosphocalcic bridges that link the HDL and phosvitin. However, when brought back to original $\mathrm{pH}$, the solubilization was reversed and returned to the original low solubility. Research by Anton (2013) shows that $\mathrm{pH}$ does not have a strong effect on the solubility and emulsifying properties of plasma, but a strong effect on granules. His study found that granules are insoluble aggregates and were essentially unusable at too low of a $\mathrm{pH}$, but become soluble micelles at a $\mathrm{pH} \sim 7$. 

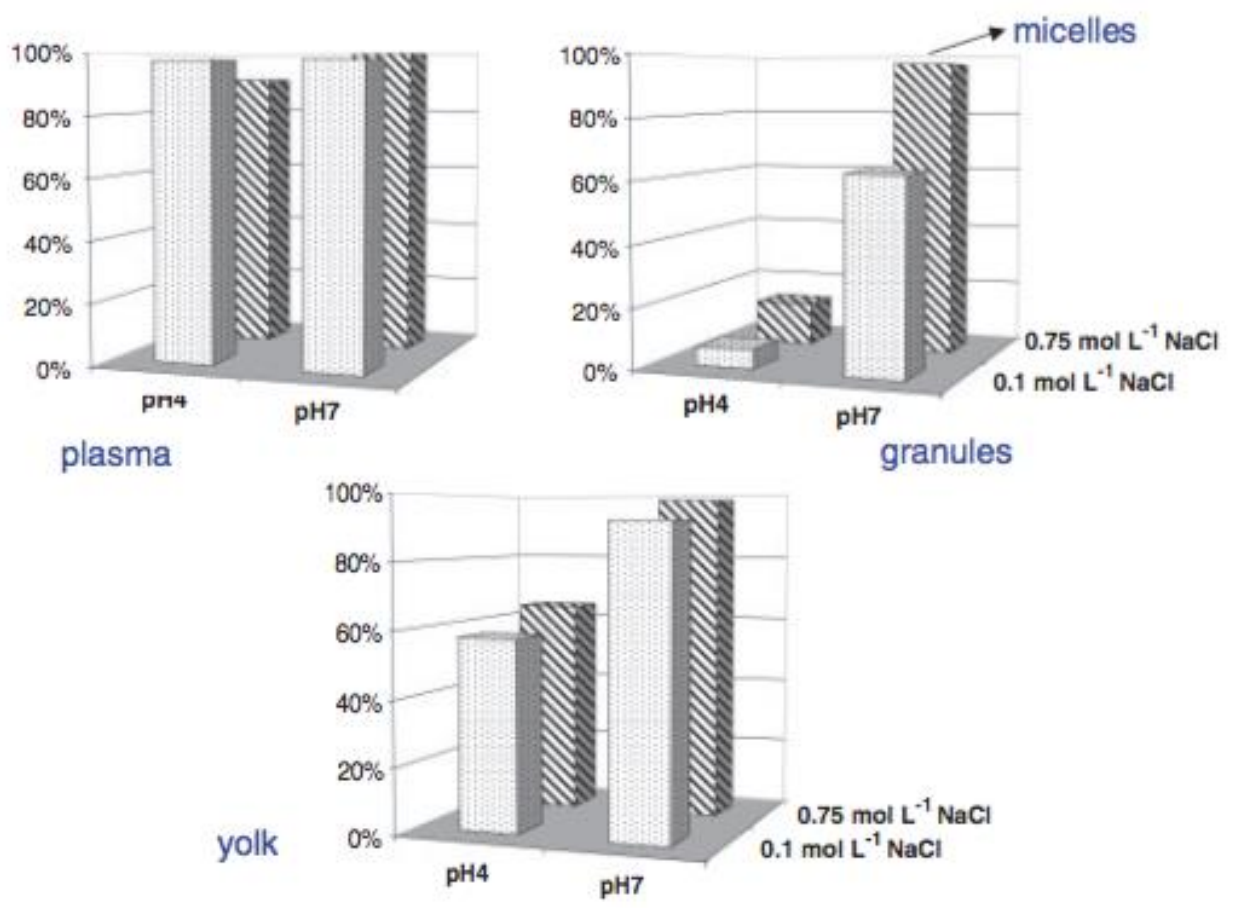

Figure 2.8 Effect of $\mathrm{pH}$ and $\mathrm{NaCl}$ on protein solubility (Anton, 2013)

\subsubsection{Temperature (Freeze/Thaw)}

The effect of temperature on egg yolk products is particularly important because egg products are often pasteurized to a temperature between $60-68^{\circ} \mathrm{C}$ microbial safety. Even so, pasteurization temperatures do not completely remove all pathogenic organisms, and egg products must be kept at $4^{\circ} \mathrm{C}$ with a limited shelf life. Studies have shown that granules are resistant to heat treatment, while plasma is sensitive. This is largely due to the denaturation that occurs in the plasma proteins, y-livetins, alivetins, and LDL (Denmat et al., 1999). The granule proteins' abilities to resist heat was originally thought to be because of the phosphocalcic bridges, but newer research suggests otherwise. A study by al Anton et al. (2000) showed that although $\beta$ phosvitin and $\beta$ HDL were not affected by heating, $\alpha$-HDL was. Since both forms of HDL are linked by the phosphocalcic bridges with phosvitin, this complex is not what 
protects the proteins from denaturation. Rather, it could be that difference in protein composition is responsible for its heat resistance. Yet, the native structure of the granules does restrict aggregation of the HDL and phosvitin, avoiding gelation and decreased protein solubility. This implies that the granules could be heated to pasteurization temperatures without losing emulsifying capabilities (Anton, 2013) A study by Denmat et al. (1999) showed the emulsifying stabilization of both granules and plasma are mostly unaffected by heat, the emulsifying activity went down for plasma above $72^{\circ} \mathrm{C}$, while granules remained unaffected.

Freezing is a way to preserve yolk and yolk products in storage over longer periods of time. Yolk undergoes gelation during freeze thawing, likely from the LDLs (Anton, 2013). Under a scanning electron microscope it was shown that an unfrozen sample of egg yolk had a close-knit structure with small voids, compared to the frozenthawed yolk. The frozen-thawed sample had a much coarser network appearance. They also saw a more open network when the samples were diluted, and conversely, an even closer knit structure upon concentration. This could mean that the addition or removal of water could result in lipoprotein destabilization and aggregation (Hasiak et al., 1972).

\subsection{Impact on Industry}

The American Egg Board (AEB) reports that today the United States produces roughly 75 billion eggs per year, at 10 percent of the world's supply. Of the supply, 60 percent are used by consumers, 9 percent used by foodservice industry, and about 
30 percent used for food manufacturing industry. As specific egg components are becoming used more and more for their functional properties in both the food and cosmetic industries, there is a growing demand for industrial scale extraction and isolation processes that are safe for consumers.

\subsubsection{Large Scale Protein Extractions}

The development of antibodies for immunotherapeutic and immunodiagnostic therapies is expanding. Because of the many advantages of chicken $\operatorname{IgY}$ over mammalian IgG, eggs as a source of antibodies is increasingly important. This poses the problem of isolating the IgY because of the high concentrations of lipids present in the egg yolk (Nilsson et al., 2008). Early publications of methods for IgY extraction were not efficient at the industrial scale, and often were not food-safe, as they relied on the use of organic solvents. Methods since have become more cost efficient and safer, utilizing salt, adjusted $\mathrm{pH}$, temperature, and food gums.

Multiple methods for extracting and isolating IgY based on a simple water dilution have been studied and published. Akita and Nakai (1992) compared four different purification methods of IgY: water dilution, polyethylene glycol, dextran sulphate, and xanthan gum. The study concluded that the water dilution was the most efficient method because the procedure was simple, produced high yields of active IgY, and can be easily adapted for large scale production. In the water dilution method described by Akita and Nakai, they used a 9:1 water to yolk dilution, incubated it at $4^{\circ} \mathrm{C}$ for 6 hours, and then centrifuged it. Upon centrifugation, the granules formed a 
compact sediment on the bottom, and the supernatant could be easily decanted off for further purification treatments.

Modifications to the basic water dilution methods have been able to improve efficiency of the purification method. Akita and Nakai (1992) used a sixfold water dilution with an adjusted $\mathrm{pH}$ of 5.0-5.2 incubated at $4{ }^{\circ} \mathrm{C}$ for 6 hours to obtain a recovery of IgY at 93-96\%. Another study by Hodek et al. (2012) utilized pH, salt, and freeze thawing in their water dilution method. They used a 1:7 water to yolk dilution at $\mathrm{pH} 5.0$, and then froze the contents to $-20 * \mathrm{C}$ and thawed before additional adjustments to the water soluble fraction. Following thawing, they adjusted the $\mathrm{pH}$ to 4.0 and added $\mathrm{NaCl}$ to a concentration of $8.8 \%$ before centrifugation. They obtained a purity of $97 \% \operatorname{IgY}$ recovery.

\subsubsection{By Products}

Eggs are becoming an important source of phospholipids and immunoglobulins, and their extractions leave large quantities of by-products behind. Many of these byproducts are full of valuable bioactive and functional elements. As the demand for these large scale extractions has been recognized over recent years, there has been a growing interest to utilize the by-products left behind.

\subsubsection{Enzymatic Proteolysis}

The by-products of egg extractions are potentially full of proteins and peptides with bioactivities. The bioactive peptides are inactive in their precursor sequence, but once 
released, interact with receptors in the body, regulating functions of systems such as nutrient uptake, immune defense, antioxidant, antimicrobial, antiadhesive, and ACEinhibitory. A common method to obtain the bioactive peptides is to use enzymatic proteolysis with enzymes from animals, plants, or microbes (Eckert et al., 2014).

A study by Eckert et al. (2014) examined the use of an unconventional proteinase from Asian pumpkin (Cucurbita ficifolia) to obtain bioactive peptides from the byproduct of a phospholipid extraction from egg yolk. They found that the serine protease from $C$. ficifolia successfully recovered peptides with ACE-inhibitory properties. Another study by Zambrowicz et al. (2012) investigated the antioxidant and antimicrobial activity of hydrolysates from egg yolk by-product after lecithin removal. They prepared hydrolysates from trypsin, chymotrypsin, and pepsin. Higher antioxidative effects were found in hydrolysates treated by trypsin and chymotrypsin than those of pepsin. They also found that the trypsin treated hydrolysates showed weak antimicrobial activity against some Bacillus species. Park et al. (2013) also looked at the antioxidative properties of peptides prepared from protein hydrolysate of lecithin-free egg yolk with the enzyme Alcalase. They found antioxidative properties present, and varied among different molecular weights.

\subsubsection{Rheological Properties}

The by-products from industrial processes have also been considered for their rheological properties in foods. After removal of livetins, the physiochemical properties of egg yolk are altered, but have potential to be salvaged as an emulsifier. 
Emulsions using this by-product are less stable than egg yolk. They have a higher viscosity and viscoelastic moduli, likely because of an increase in hydrogen bonds and hydrophobic interactions in this fraction (Zambrowicz et al., 2012). Marcet et al. (2014) considered egg yolk granules for a low-cholesterol replacer of whole egg yolk in gluten-free muffins. They found that the bakery product made with the granules was similar to the one made with whole egg yolk. However, they also found that the viscoelastic behavior of the batter was altered. The effect on the baked product was a harder muffin and a change in color. There are confirmed differences in the rheological properties of egg yolk fraction by-products compared to whole egg, and more research needs to be done with consumer testing to see if using yolk by-product as a replacement for egg is a viable option.

\subsection{Summary}

With increasing novel uses for specific egg portions in the food, cosmetic and pharmaceutical industries, there is more of a need for large scale commercial extractions. The food industry produces substantial amounts of "waste" by-products from different egg processing. These by-products are known to be rich in bioactive proteins, antibodies, and functional phospholipids (Schmidt et al., 2006). Further, Granules are often a by-product from defatted lipid and IgY extractions (Eckert et al., 2014). With the recognition of $\operatorname{IgY}$ as an important source of antibodies, there is a significant need to find uses for the granule by-product of industrial scale $\operatorname{IgY}$ extractions. While previous literature has focused on techniques for such extractions, the utilization of the protein by-products has not been widely studied and reported on. 
By adapting techniques used on whole egg yolk extractions for the granule byproduct portion, there is potential for separation of more proteins. Addition of salt is a known way to disrupt the granule fraction. Further, the change of density with addition of salt inverts the granules above the water soluble (WS) layer. This adaptation could optimize the processing and collection of protein by eliminating unnecessary steps and equipment used to siphon the WS layer from the top, and instead collect it from the bottom of the tank.

Consequently, this project seeks to find potential uses for protein by-products of industrial IgY extractions by further treatment (filtration, salt addition, and $\mathrm{pH}$ adjustment). Based on previous literature, the following hypotheses were developed:

1) The egg yolk granule by-product can further fractionate and recover more water soluble proteins from lipid fraction by mechanical treatment (filtration and centrifugation).

2) The amount of crude protein salvaged from egg yolk granule by-product can be increased/optimized with changes in $\mathrm{pH}$ and salt concentration.

3) Recovered protein and protein hydrolysates can have antibacterial properties against Escherichia coli (E. coli)

The objectives of this study include:

1) To characterize the recovered protein after the different treatments (mechanical, salt, $\mathrm{pH}$ ) in yolk by-product.

2) To determine the protein concentration at which antibacterial properties are effective against $E$. coli 
3) To use salt to attempt to invert the fractionation of the insoluble yellow layer on top and water soluble layer on bottom for ease of collection. 


\section{CHAPTER 3: MATERIALS AND METHODS}

\subsection{Yellow Cake Collection and Standardization}

\subsubsection{Collection}

A by-product from an experimental pilot plant IgY extraction, which will be called yellow cake, was obtained from lipoprotein fraction of a 3 part water soluble protein extraction from a project run by Nestle. Pasteurized, non-homogenized, egg yolk product used for original Nestle extraction was prepared by La Belle Associates, Inc. Sixty pounds of egg yolk were added to stainless steel conical tank. After a 10 fold water egg yolk dilution was made, stirred for six hours, and allowed to settle for 12 hours, a yellow lipoprotein sedimentation formed on the bottom of the tank, showed in Figures 3.1 and 3.2 A lobe pump was used to siphon out the water soluble IgY fraction from the tank. The sediment was diluted again following the same steps twice more. The water soluble fraction was used for further isolation and purification for an industry project, leaving behind a yellow lipid/protein sedimentation on the bottom of the tank. This waste layer, the yellow cake, was collected in containers by opening the valve at the bottom of the tank. After collection, the yellow cake was frozen in sanitized plastic tubs and stored at $-20^{\circ} \mathrm{C}$ degrees. Three independent replicates of yellow cake samples were obtained from different weeks. 


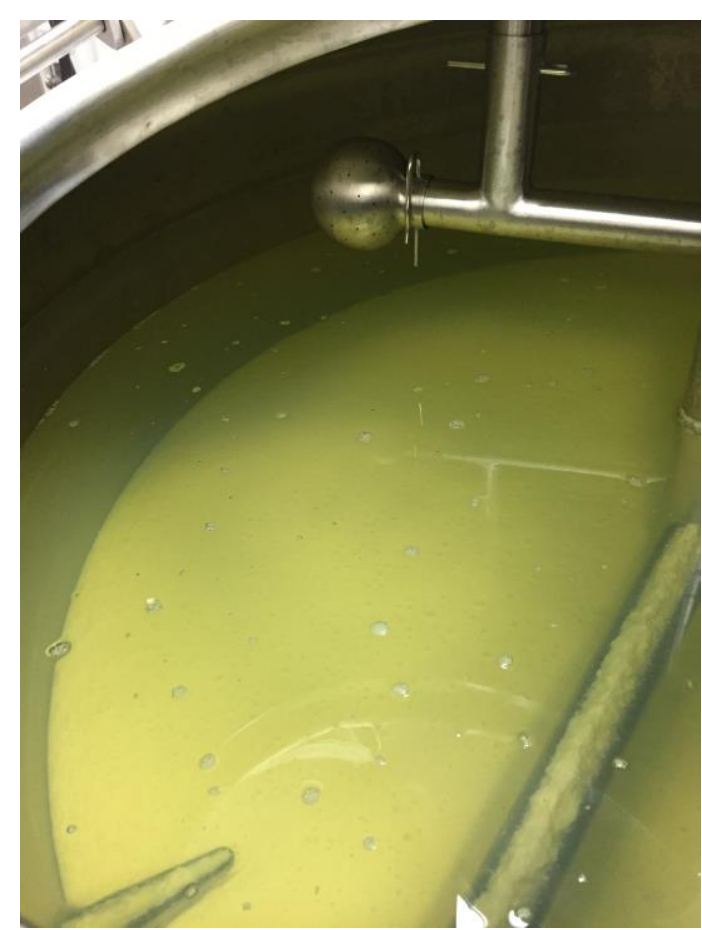

Figure 3.1 Phase Separation of egg yolks during IgY extraction. Water soluble layer is visible over lipid layers

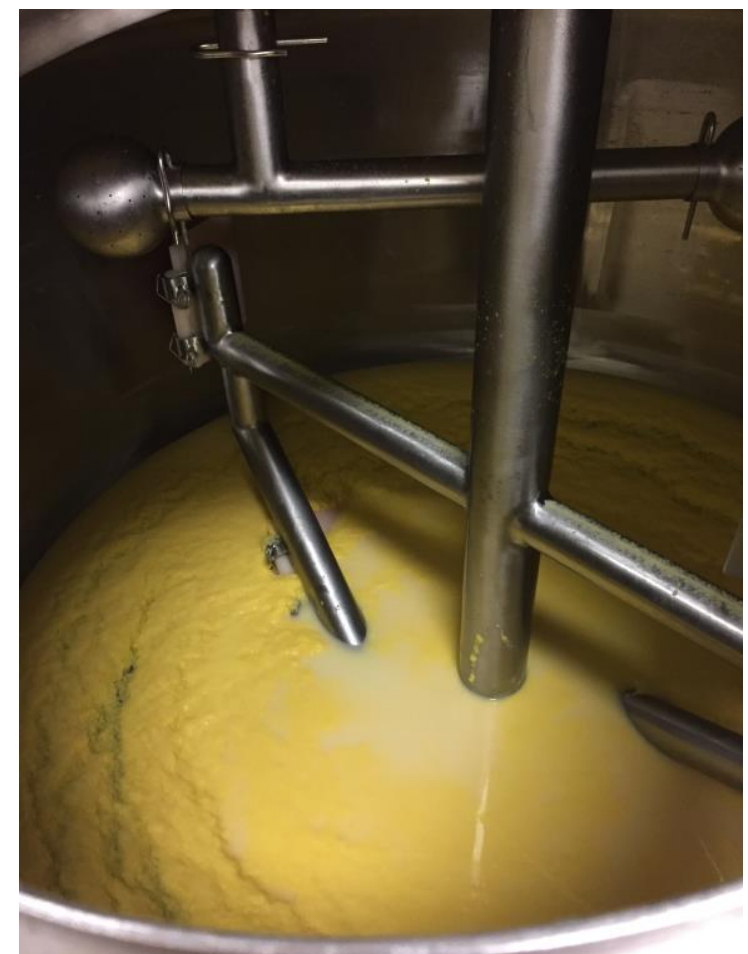

Figure 3.2 Yellow cake solids in tank before removal (work of this thesis project) 


\subsubsection{Standardization}

Frozen samples of yellow cake were given forty-eight hours to thaw at $4^{\circ} \mathrm{C}$. Once thawed, the yellow cake was gently stirred continuously for one minute to ensure a homogenous sample. The CEM LabWave9000 Microwave Moisture/Solid Analyzer was then used to measure the percent total solids of the yellow cake under the settings for cream. The percent solids readings were taken three times and then averaged. The results were used to dilute the yellow cake to a solution of five percent solids in tap water. The samples were prepared in seven 10 gallon, stainless steel milk cans at 15 pounds of solution each.

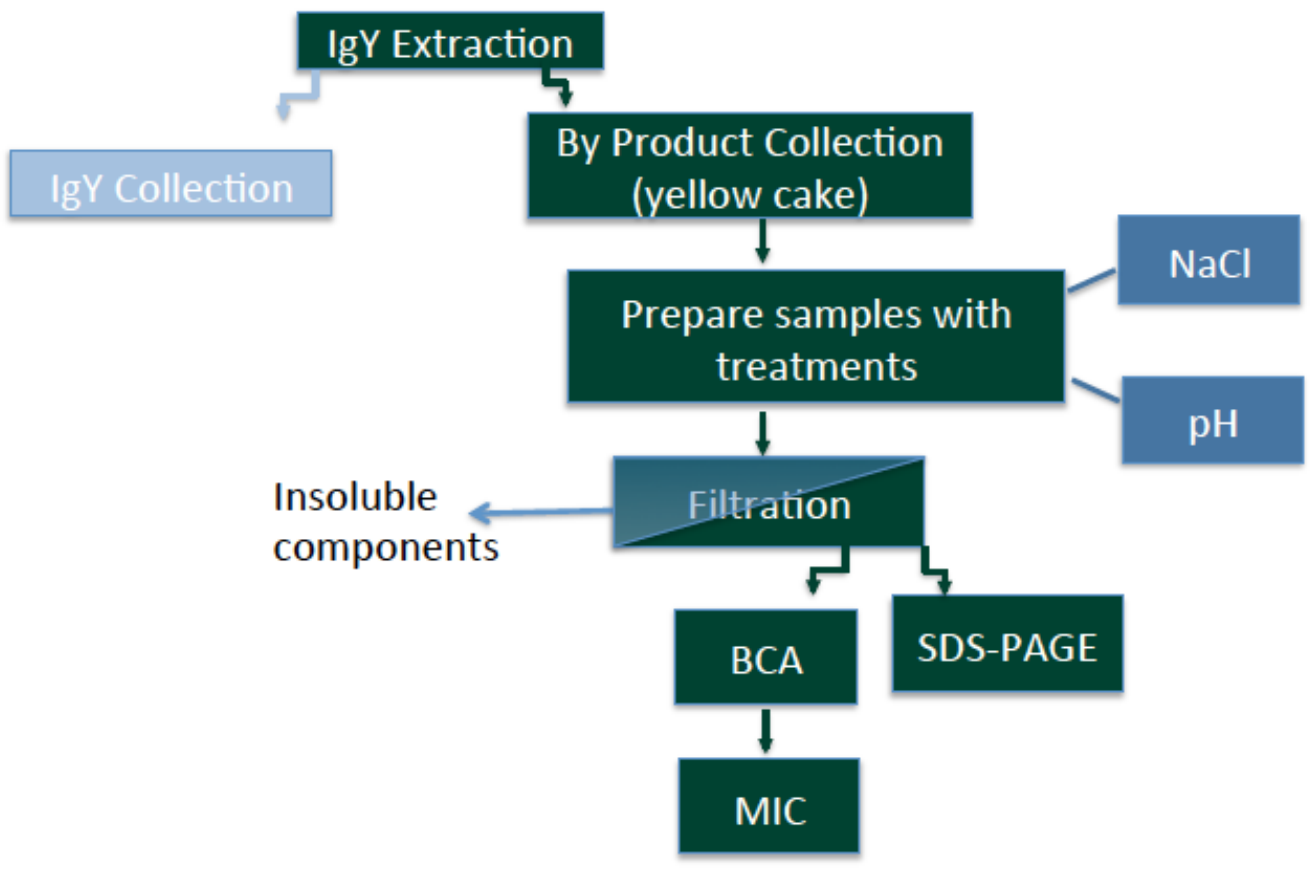

Figure 3.3 Flow diagram indicating the procedure to generate the samples and treatments in this work. 


\subsection{Sock Filtration}

\subsubsection{Sample Preparation}

The five percent solids yellow cake solutions were prepared at four different $\mathrm{pHs}$ : 4.6 $\pm 0.05,4.8 \pm 0.05,5.0 \pm 0.05$, and $5.2 \pm 0.05$. Experimental treatmeants are shown in Figure 3.3. A 10\% Lactic Acid solution was added to the fifteen pounds of yellow cake solution to adjust $\mathrm{pH}$. These four solutions at different $\mathrm{pHs}$ had no salt added. PerpHecT digital LogR Advanced Benchtop $\mathrm{pH} / \mathrm{mV} / \mathrm{ORP} /$ Temperature Meters Orion 350 was used for $\mathrm{pH}$ measurements.

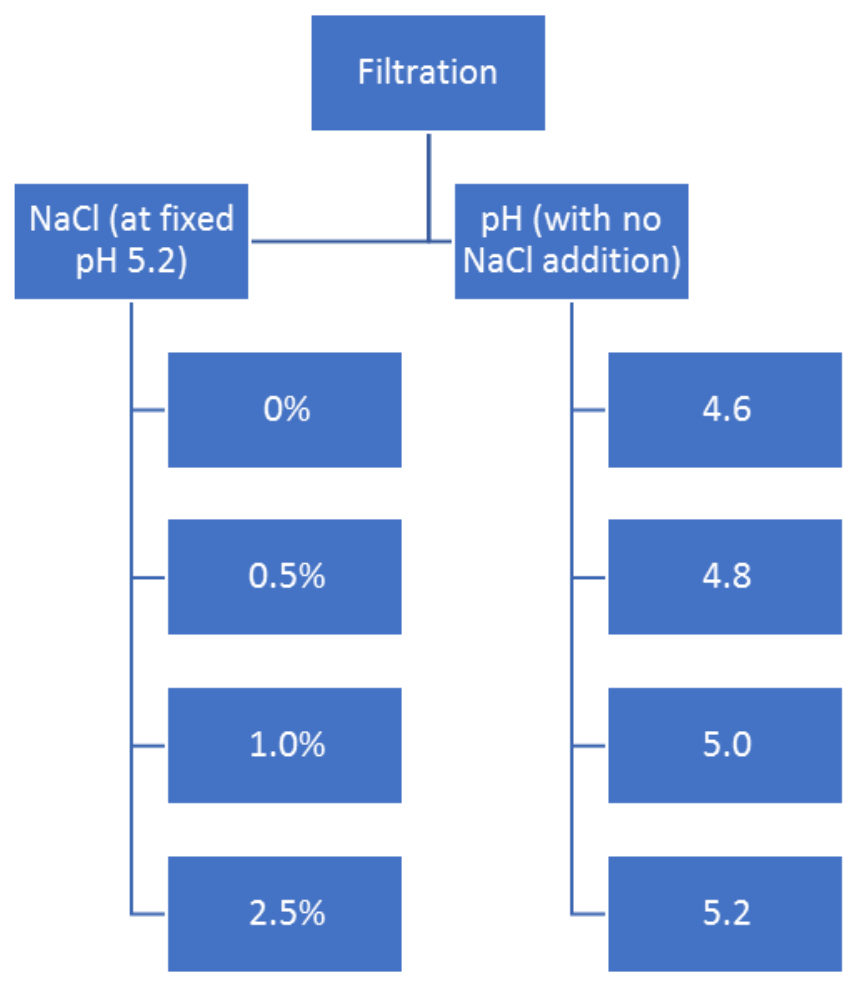

Figure 3.4 Experimental Design for Sock Filtration Experiment

The five percent solids yellow cake solutions were prepared at four different $\mathrm{NaCl}$ concentrations by weight: $0 \%, 0.5 \%, 1 \%$, and $2.5 \%$. $\mathrm{NaCl}$ was added to milk cans 
with $15 \mathrm{lbs}$ of yellow cake solution and mixed vigorously for two minutes before $\mathrm{pH}$ adjustment.

\subsubsection{Filtration}

Tri Clover Mainstream filter, shown in Figure 3.5, was used with a 100 micron mesh sock filter to pass through the yellow cake solutions through the first pass. The solution was pumped through the filtration system. A hose was used to pass the treated yellow cake samples through the pump, which connected to the filter system via a plastic hose, and passed through the 100 micron filter and out of stainless steel piping. Tap water was run through the filter first for thirty seconds, and then the yellow cake solution was pumped through, and filtrate collected into clean milk cans for a second pass. A second pass was repeated with the filtrate through a 10 micron felt sock filter. Filters were cleaned and changed, and system was emptied and cleaned in between each sample can. 


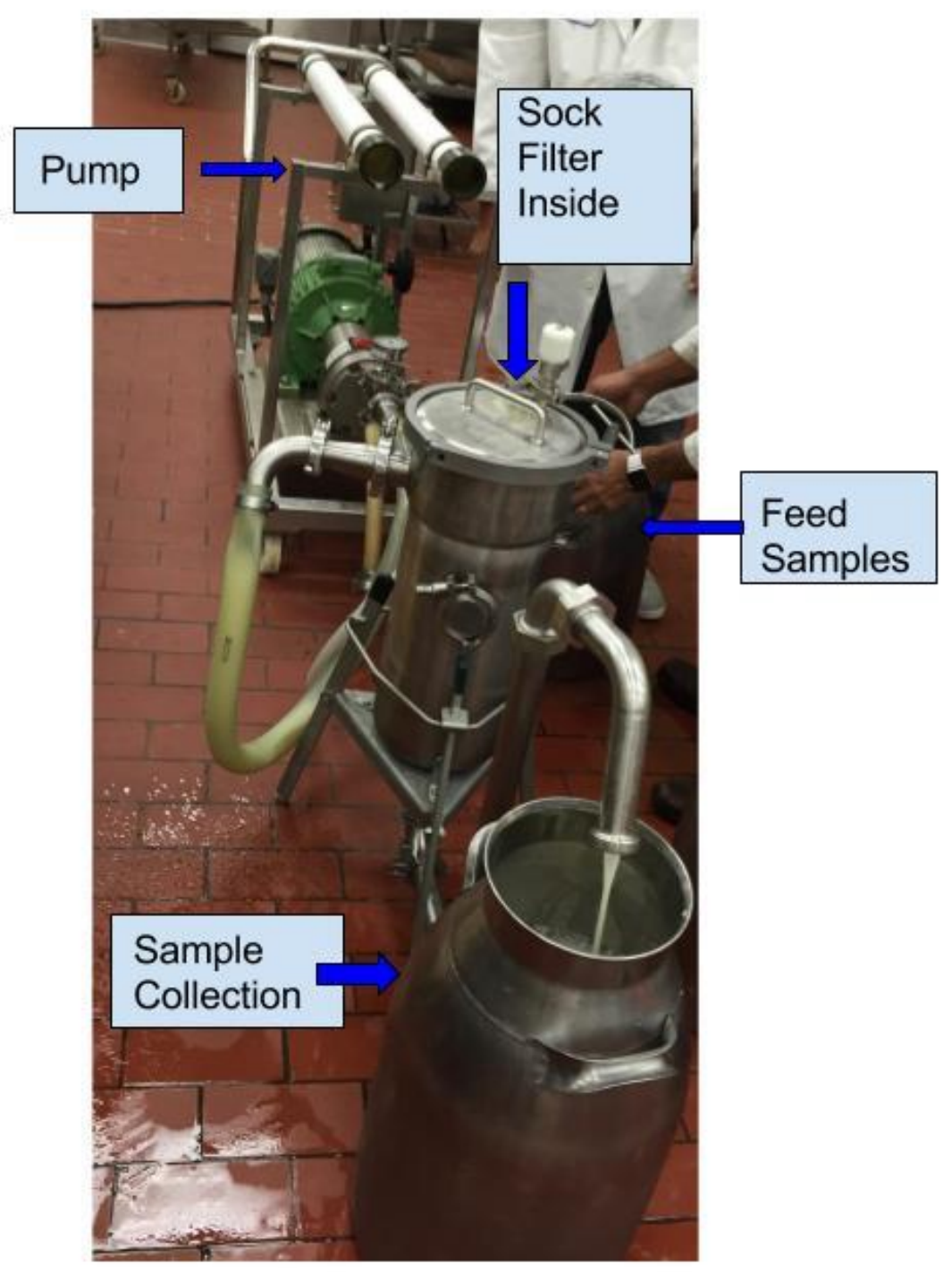

Figure 3.5 Sock Filtration Set up 


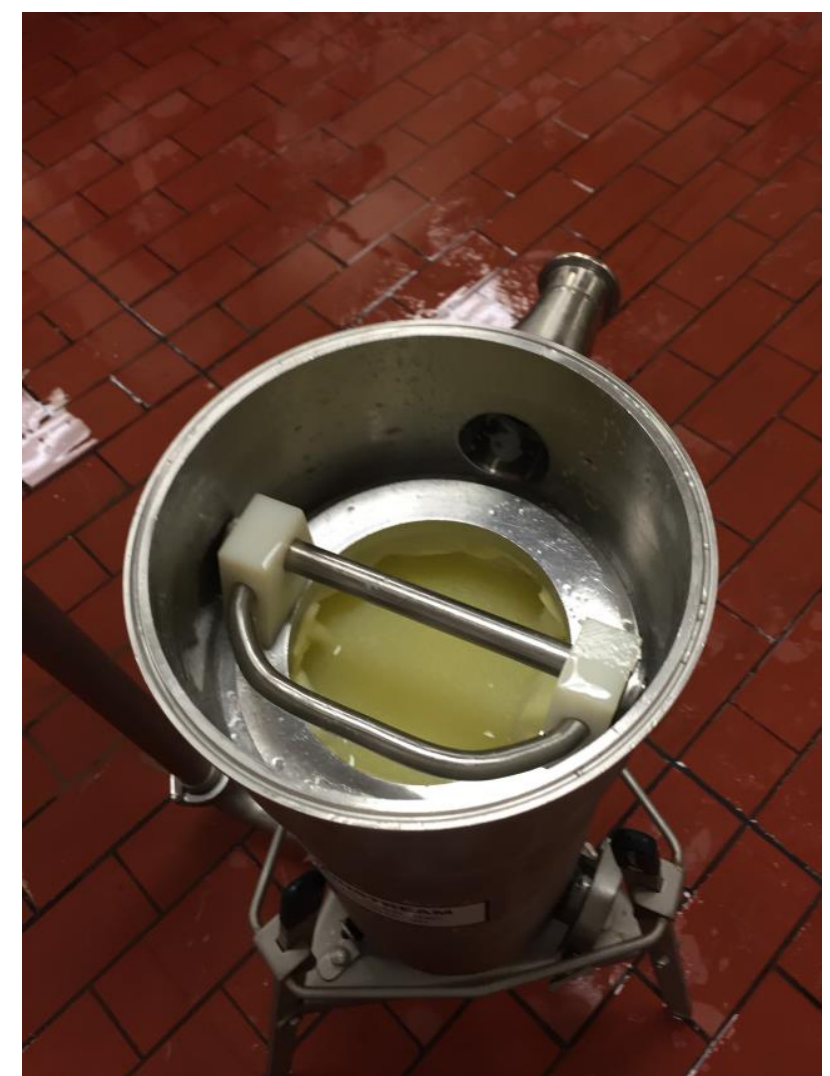

Figure 3.6 Filter after running samples through

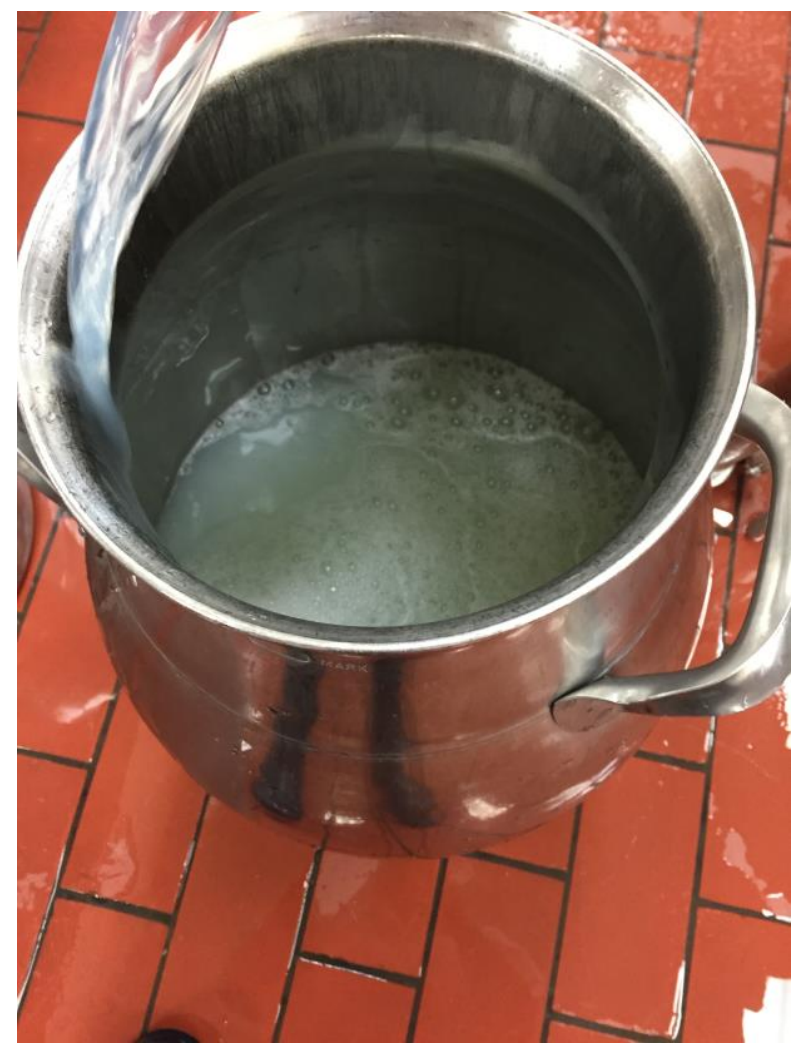

Figure 3.7 Filtrate samples collected after passing through filter system 


\subsubsection{Sampling}

After pushing water through the filter, the samples were pushed through and after 30 seconds the filtrate started to come through yellowish in color. After another 30 seconds upon color change, samples were collected in milk cans until all of the sample was pushed through, shown in Figure 3.6 and 3.7. Additional water was pushed through after all of the sample solution was taken up. Thirty seconds after the water was added, sample collection stopped and the remainder filtrate was discarded. This was to ensure a consistent sampling procedure to optimize a most pure sample undiluted with the initial water and final water. Yellow lipid solids left in filter were discarded. The collected protein solution was kept for analysis.

\subsubsection{Filtrate Storage}

Two complete sample sets of filtrate (protein) for each of the three trials were stored in Falcon $50 \mathrm{~mL}$ Conical Centrifuge tubes for analysis. Remaining samples were stored in $7 \mathrm{oz}$ Whirl-Pak write on bags used for the precipitation portion of the project. Upon collection and bagging, they were immediately frozen at $-20^{\circ} \mathrm{C}$ degrees until analysis.

\subsection{Precipitation}

\subsubsection{Sample preparation}

Frozen samples of yellow cake solids were thawed and standardized to a five percent solids solution in water with the same procedure as 3.1 .2 at a lab scale. $500 \mathrm{~mL}$ of 
solution were prepared in $1000 \mathrm{~mL}$ glass beaker. Yellow cake solution was distributed into ten Falcon $50 \mathrm{~mL}$ Conical Centrifuge tubes, with $30 \mathrm{~mL}$ in each tube. Preliminary experimentation showed that a minimum of $2.5 \% \mathrm{NaCl}$ yellow cake solution was needed in order to make the lipid layer start to separate and float separation after centrifugation. $\mathrm{NaCl}$ concentration of each tube was adjusted to $3 \%, 4 \%, 5 \%, 6 \%$, and $7 \%$. Appropriate weights of $\mathrm{NaCl}$ were measured and added to the solutions. They were then dissolved by vigorously shaking the tubes by hand. Two tubes were made of each concentration. Figure 3.8 shows a flow of this experiment.
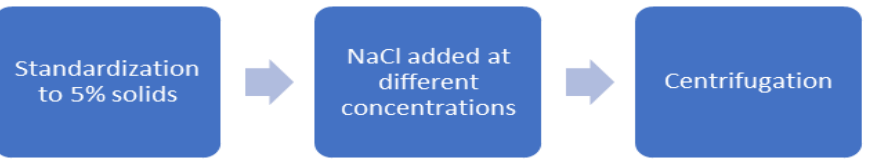

Discard lipid

pellicle. Collect

water soluble

fraction in clean

tube

\section{Adjust pH \\ to 4.0

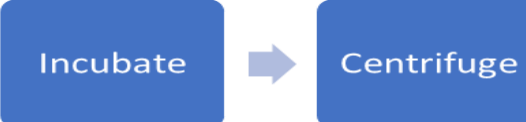 \\ Save pellet \\ for \\ analysis}

\section{Figure 3.8 Precipitation Design Flow}

\subsubsection{Centrifugation}

Eppendorf Centrifuge $5810 \mathrm{R}$ was used to centrifuge the samples in the $50 \mathrm{~mL}$ falcon tubes samples were prepared in at $4000 \mathrm{RPM}$ for $20 \mathrm{~min}$ at $4^{\circ} \mathrm{C}$. After centrifugation, a gelatinous yellow layer of lipid was on the top with a clear layer on the bottom. The clear water soluble layer from each sample was extracted using a $50 \mathrm{~mL}$ pipette and put into a new $50 \mathrm{~mL}$ falcon tube. The lipid layers were discarded. 


\subsubsection{Acidification and incubation}

Hydrochloric acid .5M ( $\mathrm{HCl})$ was used to acidify all of the remaining water soluble portion of the samples to $\mathrm{pH} 4 \pm 0.05$. One sample tube of each salt concentration was left to incubate at room temperature for 1.5 hours, while the other sample tube for each salt concentration was incubated at $4^{\circ} \mathrm{C}$ for 1.5 hours. After the incubation period, samples turned to a milky white color, and started to have sediment settle at the bottom. All sample tubes were centrifuged a second time at 4000 RPM for 20 minutes at $4^{\circ} \mathrm{C}$.

\subsubsection{Collection and storage}

After second centrifugation, white pellets formed on the bottom of each falcon tube, with a distinct clear layer on the top of all but two tubes. The tubes with $3 \% \mathrm{NaCl}$ had some yellow particles still suspended in the water. The water layer was decanted for each tube and discarded. The pellets were each dissolved in $5 \mathrm{~mL}$ of DI water and stored at $4^{\circ} \mathrm{C}$ for one day until analysis.

\subsection{Protein Analysis}

\subsubsection{Protein quantification}

\subsubsection{Preparation}

The frozen treated samples of yellow cake were taken out of the freezer to thaw overnight for protein analysis. Samples were balanced and put in Falcon $15 \mathrm{~mL}$ Conical Centrifuge tubes. An Avanti J-E Centrifuge (Beckman Coulter) was used to 
centrifuge samples at 4,500 RPM for 15 minutes at $4^{\circ} \mathrm{C}$ with a JS-5.3 rotor. Supernatent was analyzed.

\subsubsection{BCA}

A bicinchoninic acid (BCA) Protein Assay Kit (Pierce Biotechnology, Rockford, IL) was used to detect and quantify the total protein. To prepare the protein standard for the appropriate working range for the Microplate Procedure (Pierce Biotechnology Rockford, IL), a $1 \mathrm{~mL}$ ampule containing bovine serum albumin (BSA) at $2 \mathrm{mg} / \mathrm{mL}$ in $0.9 \%$ saline and $0.05 \%$ sodium azide was diluted into mini eppendorf tubes $(.5 \mathrm{~mL})$ using DI water as the diluent. The samples were prepared in two different dilutions to assure the samples would fall into the working range. Preliminary studies showed that all samples would have best results undiluted or with a 1:9 dilution. Samples were run undiluted, as well as 1:9 dilution. The following formula was used to calculate the total volume of working reagent (WR) required:

The WR was prepared by mixing 50 parts of BCA Reagent A from the kit with 1 part of BCA Reagent B. Reagent A contained of sodium carbonate, sodium bicarbonate, bicinchoninic acid and sodium tartrate in $0.1 \mathrm{M}$ sodium hydroxide. Reagent $\mathrm{B}$ contained 4\% cupric acid. WR was prepared immediately before use. Twenty five $\mu 1$ of each sample were pipetted into separate wells in a 96 well microplate (Pierce Biotechnology Rockford, IL). $25 \mu \mathrm{L}$ of each standard were also pipetted into separate wells. Each sample and standard were run in duplicate and averaged. $200 \mu \mathrm{L}$ of the WR was added to each well and mixed on a shaker plate for 30 seconds. The plate 
was covered with parafilm and incubated at $37^{\circ} \mathrm{C}$ for 30 minutes. Following incubation, the plate was cooled to RT. The absorbance was measured at $562 \mathrm{~nm}$ on a plate reader. A molecular devices SpectraMax M2e device was used to read absorbances.

\subsubsection{Protein characterization}

\subsubsection{Preparation}

SDS-PAGE was used to characterize the proteins in different treatments of $\mathrm{pH}$ and salt concentration in the filtration experiment and for the different concentrations of salt and temperature in the precipitation experiment. Samples analyzed with SDSPAGE were from the same preparation and sample pool as section 3.4.1.1. The samples were then diluted in a 1:1 ratio with Lammeli buffer. To prepare the sample buffer, 2x Lammeli buffer (Bio-Rad Laboratories, Hercules, CA) was mixed in a 19:1 dilution with $\beta$-mercaptoethanol (ME) (Fisher Scientific). $1.9 \mathrm{~mL}$ of $2 x$ Lammeli buffer was mixed with $100 \mathrm{uL}$ of ME. $50 \mu \mathrm{L}$ of buffer were mixed with $50 \mu \mathrm{L}$ of sample in mini eppendorf tubes. Tubes were boiled for 5 minutes. After cooling to room temperature, samples were centrifuged in a minispin plus eppendorf centrifuge (Sigma-Aldrich) for 60 seconds at 12,000 RPM. For the precipitation experiment, samples from section 3.3.4 were shaken on a vortex for 30 seconds each before gel preparation same as above. However, the precipitation samples were additionally prepared in a 1:10 dilution with buffer. 


\subsubsection{Gel Electrophoresis}

Mini-PROTEAN TGX Precast 4-20\%, 10 comb, 50 uL well Gels (Bio-Rad Laboratories, Hercules, CA) were assembled into running module cells and chambers were filled with 1X Tris-Glycine-SDS buffer(Bio-Rad Laboratories, Hercules, CA). $10 \mathrm{uL}$ of Precision Plus Protein Dual Color Standards (Bio-Rad Laboratories, Hercules, CA) and $10 \mathrm{uL}$ of each prepared sample were loaded into each well. The gels were run with a Bio Rad PowerPac Basic power supply at $90 \mathrm{~V}$ until the protein bands entered the resolving gel. The voltage was then increased to $110 \mathrm{~V}$ until the bands reached the reference lines and power turned off. The process took approximately one hour and forty five minutes.

Gels were stained for 48 hours in Coomassie Brilliant Blue with shaking. Following staining, gels were destained with destaining solution(40\% methanol, $10 \%$ acetic acid, 50\% deionized water). Gels sat in destain solution with shaking for 20 minutes, then the destain solution was changed out for fresh and remained destaining for 24 hours. After 24 hours, the gels were rinsed with DI water. The gels were imaged on a Molecular Imager Gel Doc XR+ with Image Lab 4.1 Software (Bio-Rad laboratories, Hercules, CA) with Trans white light. 


\subsection{Antibacterial Function of bioactives}

\subsubsection{Bacteria and broth preparation}

\subsubsection{E. coli}

E. coli strain ATCC 25922 was grown on LB media using the streak plate method from pure culture. Plate was incubated overnight at $37^{\circ} \mathrm{C}$. The next day the E. coli was inoculated in liquid media. $3 \mathrm{~mL}$ of sterile Mueller Hinton broth were added to sterile test tube. Bacteria sample was scooped from plate into test tube and then incubated for 24 hours at $37^{\circ} \mathrm{C}$. Prior to MIC procedure, turbidity of E. coli was adjusted to $1-2 \times 10^{\wedge} 8 \mathrm{cfu} / \mathrm{mL}$ at OD 600 . A blank cuvette of $1 \mathrm{~mL}$ of MHB broth was run at $600 \mathrm{~nm}$ in the SpectraMax M2e, followed by a 1:10 dilution of the bacterial culture. The results were a concentration of $1.7 \times 10^{9} \mathrm{cfu} / \mathrm{mL}$.

\section{Equation 1. To calculate $5 \mathrm{~mL}$ of $10^{\wedge} 8 \mathrm{cfu} / \mathrm{mL}$ of $E$. coli $\left(1.7 \times 10^{\wedge} 9\right) / \mathrm{mL}(\mathrm{X})=\left(1 \times 10^{\wedge} 8\right) / \mathrm{mL} \times(5 \mathrm{~mL})$ $\mathrm{X}=0.294 \mathrm{~mL}$ of $E$. coli in $4.7 \mathrm{~mL}$ of $\mathrm{MHB}$} $200 \mathrm{uL}$ of adjusted bacterial suspension was added to $19.8 \mathrm{~mL}$ of sterile MHB to prepare $20 \mathrm{~mL}$ of a 1:100 dilution of inoculum.

\subsubsection{Broth}

Mueller Hinton Broth was prepared by adding DI water to a flask with MHB powder. It was stirred with heating until dissolved. It was then autoclaved for 15 minutes, and cooled and stored until use. 


\subsubsection{Minimal Inhibitory Concentration (MIC)}

The MIC procedure used was adapted from the method described in Nature Protocols by Wiegand et al. (2008). This procedure was mostly used to find the MIC for antibiotic drugs, but was adapted for proteins and peptides with bacteriostatic properties.

\subsubsection{Protein standardization and preparation}

BCA was run (Section 3.4.1) on filtration protein samples immediately prior to MIC procedure. Results from $\mathrm{BCA}$ were used to standardize solution concentrations of 256 $\mu \mathrm{g} / \mathrm{mL}$ of crude protein in MHB. Protein samples were diluted in MHB for MIC plates without TrypZean. Protein samples were diluted in PBS (Bio-Rad Laboratories, Hercules, CA) for proteolyzed plates. $1 \mathrm{~mL}$ of each sample was prepared.

\subsubsection{Controls}

Each MIC microtiter plate had 3 individual columns controlling for three different variables. The unhydrolyzed plates each had one column with a mixture of E. coli and MHB with no protein to ensure adequate bacteria growth from culture. The proteolyzed plates had this column with PBS as well, to ensure the growth in the presence of PBS. Each plate had one column of the standardized $256 \mu \mathrm{g} / \mathrm{mL}$ protein samples with broth and no bacteria to control for contaminated protein. The non proteolyzed plates also had a column with just broth to control for contaminated broth. The proteolyzed plates had this column with MHB and PBS. 


\subsubsection{Dilutions}

For each trial, $50 \mathrm{uL}$ of MHB were pipetted into columns 2-10, and 12 of independent sterile 96 microtiter plate. $100 \mathrm{uL}$ of MHB was added into column 11. For each row $100 \mathrm{uL}$ of standardized $256 \mu \mathrm{g} / \mathrm{mL}$ peptide solution was pipetted into column 1 . Hydrolyzed plates used the digested samples to be described in the next section. For each row, $50 \mathrm{uL}$ from column 1 was withdrawn and pipetted into column 2 with a multichannel micropipette. This step was repeated for dilution up until column 9. Fresh tips were changed for each withdrawl, and lids were kept close on microtiter plates were on whenever not in use to minimize chance of contamination.

\subsubsection{Inoculation}

Each well containing the peptide solution and growth control well were inoculated with $50 \mu \mathrm{L}$ of the bacterial suspension. This resulted in the desired inoculum of $5 \mathrm{x}$ $10^{\wedge} 5 \mathrm{cfu} / \mathrm{mL}$. The microtiter plates were then incubated at $37^{\circ} \mathrm{C}$ for 20 hours. After the 20 hours, the plates were observed and minimum inhibitory concentrations determined by growth/no growth across the plates. Figure 3.9 visualizes the plate. 


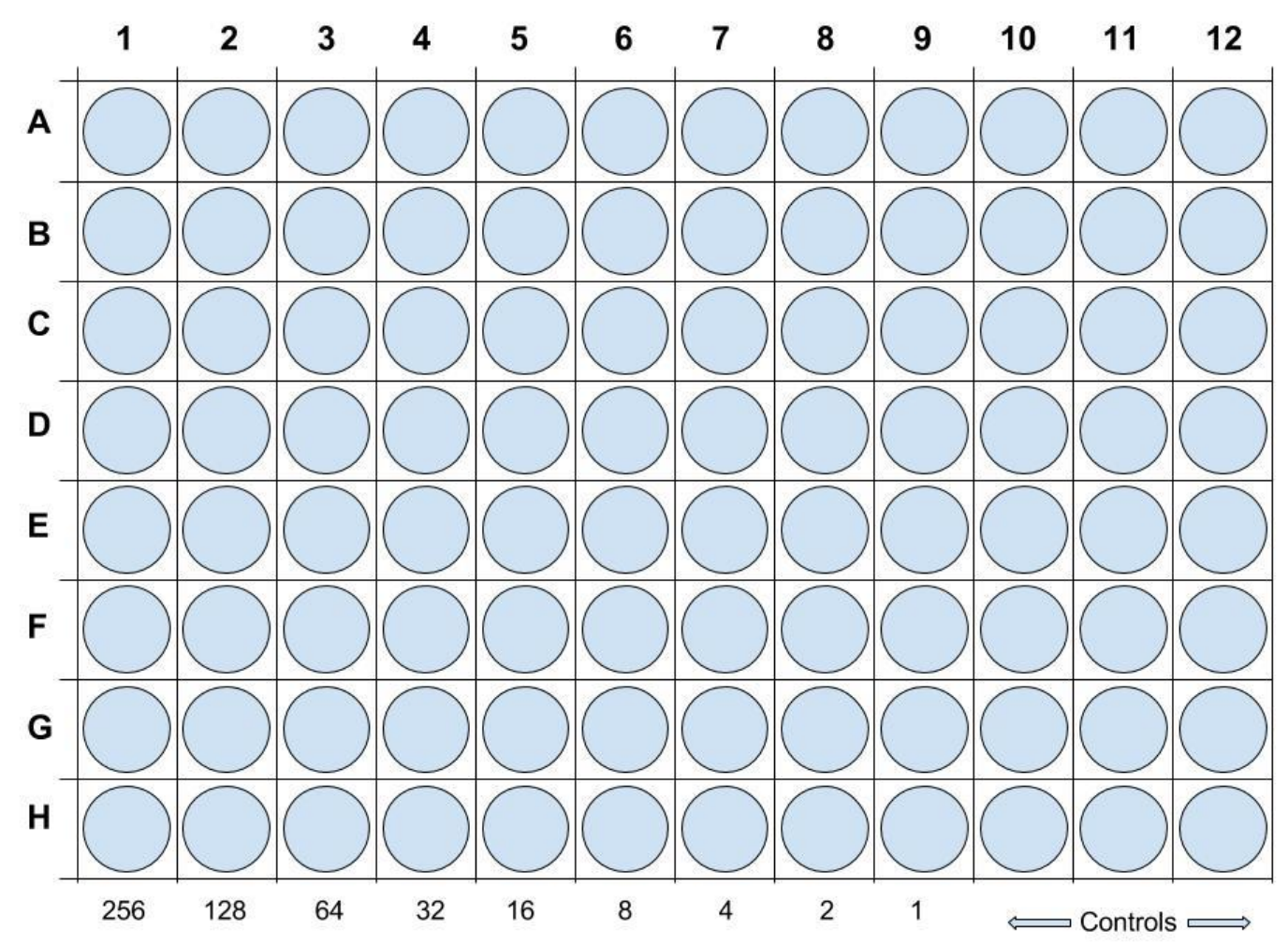

Figure 3.9 Example of MIC plate. Protein across rows is in $\mu \mathrm{g} / \mathrm{mL}$

\subsection{Enzyme Digest}

\subsubsection{TrypZean preparation}

Sample of TrypZean from Cal Poly with a specific activity of 4538 USP units/mg was used to digest protein samples from the filtration experiment. To prepare a $20 \mathrm{mg} / \mathrm{mL}$ concentration of TrypZean, $10 \mathrm{mg}$ of lyophilized dessicated TrypZean powder was mixed into $500 \mathrm{uL}$ of $1 \mathrm{mM} \mathrm{HCl}$. To make the $1 \mathrm{mM} \mathrm{HCl}, 100 \mathrm{uL}$ of $1 \mathrm{M} \mathrm{HCl}$ were added into $99.9 \mathrm{~mL}$ of DI water.

\subsubsection{Proteolysis}

The MIC assay was run both with and without proteolysis on the samples. Each trials 1-3 had their own plate for an MIC assay without proteolysis performed, and each 
had a separate plate for proteolysis without an endpoint. Trial 2 had 2 additional plates to test proteolysis with an endpoint.

$2.56 \mathrm{uL}$ of prepared TrypZean were added to each standardized protein sample from trials $1-3$ and incubated for 2 hours at $37^{\circ} \mathrm{C}$. For trial 2 samples this portion was run an additional 2 times to test different endpoints. After incubation period, one set of trial 2 samples were boiled for 5 minutes. One set from trial 2 samples were heated to $50^{\circ} \mathrm{C}$ for 5 minutes. All other samples had no endpoint. These samples were then pipetted into wells on microtiter plate for serial dilution and inoculated according to the same procedure in 3.5.2.3 and 3.5.2.4.

\subsection{Statistical Analysis}

JMP pro 13 was used for analysis in the sock filtration experiment. Response for protein amount was analyzed using a two factor ANOVA. Results were considered significant with a p-value $<0.05$. Statistical analysis and graphs for the raw data can be found in the appendix as noted. 


\section{CHAPTER 4: RESULTS AND DISCUSSION}

\subsection{Sock Filtration}

\subsubsection{Protein Content}

SDS-PAGE was used to profile the proteins contained in the yellow cake after filtration. Samples were subjected to and analyzed under seven different conditions, considering two variables: $\mathrm{NaCl}$ content and $\mathrm{pH}$. After diluting samples, gels were run accordingly, taking care that the tracking dye did not travel farther than the bottom of the gels. Gels were stained using Coomassie Brilliant Blue to view the bands.

Figures 4.1, 4.2, and 4.3 illustrate the protein content in the three replicated trials for the sock filtration. For all all three figures: Lane one represents the protein standard. Lane 2 represents $0 \% \mathrm{NaCl}, \mathrm{pH}$ of 5.2. Lane 3 represents $0.5 \% \mathrm{NaCl}, \mathrm{pH}$ of 5.2. Lane 4 represents $1 \% \mathrm{NaCl}, \mathrm{pH}$ of 5.2. Lane 5 represents $2.5 \% \mathrm{NaCl}, \mathrm{pH}$ 5.2. Lane 6 represents $0 \% \mathrm{NaCl}, \mathrm{pH}$ of 4.6. Lane 7 represents $0 \% \mathrm{NaCl}, \mathrm{pH}$ of 4.8. Lane 8 represents $0 \% \mathrm{NaCl}, \mathrm{pH}$ of 5.0 .

\footnotetext{
All three trials showed the same migration patterns. Most bands appeared in the 37-75 $\mathrm{kDa}$ range, though some very light. In all seven treatments, two most distinct bands appeared at $75 \mathrm{kDa}$ and $\sim 45 \mathrm{kDa}$. There were also lighter, but distinct bands among all samples at 37 and $\sim 65 \mathrm{kDa}$, although barely detectable in trial 3 image. In the image for trial 2, lanes 4 and 8 have extra bands appearing at 125 and $\sim 119 \mathrm{kDa}$. In all images, lane 5 had much darker, distinct bands, as well as more bands. These bands
} 
appeared at $250 \mathrm{kDa}, \sim 30($ absent in trial 1) $\sim 8, \sim 13$, and a darker diffuse band between 100-130 kDa (faint in trial 1). In general, bands were most pronounced in trial 3, and faintest in trial 1.

Bands were compared to known weights of expected proteins in previous literature. Protein identities were estimated by comparison with mobilities of standards. The prominent band at $75 \mathrm{kDa}$ appeared across all trials and treatments, as expected, because it corresponds with one of the major apoproteins apparent in all fractions of egg yolk in previous literature (Itoh et al., 1986). The other prominent band that appeared on trials and treatments at $\sim 45 \mathrm{kDa}$ confirmed the presence of $\beta$-phosvitin (Abe et al., 1982; Itoh et al., 1986, Ko et al., 2011) The $37 \mathrm{kDa}$ band is estimated to be $\alpha$-phosvitin or riboflavin binding protein (RFB) (Abe et al., 1982; Awade, 1995). The bands at $65 \mathrm{kDa}$ and $125 \mathrm{kDa}$, and $250 \mathrm{kDa}$ could be attributed to one of the main apoproteins of LDL (Itoh et al., 1986).

Lane 5 had $2.5 \% \mathrm{NaCl}$ and a $\mathrm{pH}$ of 5.2. It had 5 unique and distinct bands that the other samples at $5.2 \mathrm{pH}$ with less salt concentrations did not have. These bands were at $\sim 225, \sim 13,7 \sim, \sim 30$, and $\sim 100$. Additionally, these bands were unique among the other $\mathrm{pH}$ samples with $0 \% \mathrm{NaCl}$ concentrations. Bands at $\sim 7$ and $\sim 13$ were likely apolipovitellenins. (Awade, 1995; Zambrowicz et al., 2014; Anton and Gandemer, 1997) The band at $\sim 30$ corresponds to an apoprotein of HDL (Mine, 2008). It is likely that the higher salt concentration solubilized more proteins out of the yellow cake solution by disruption of the granule structure. At full disruption of granules, the 
presence of more unique proteins is likely due to the broken HDL-phosvitin complexes allowing those proteins to be released and solubilized in this environment. In salt concentrations under $2.5 \%$, there are still different proteins and peptides that are bound in the phosvitin-HDL complexes. 


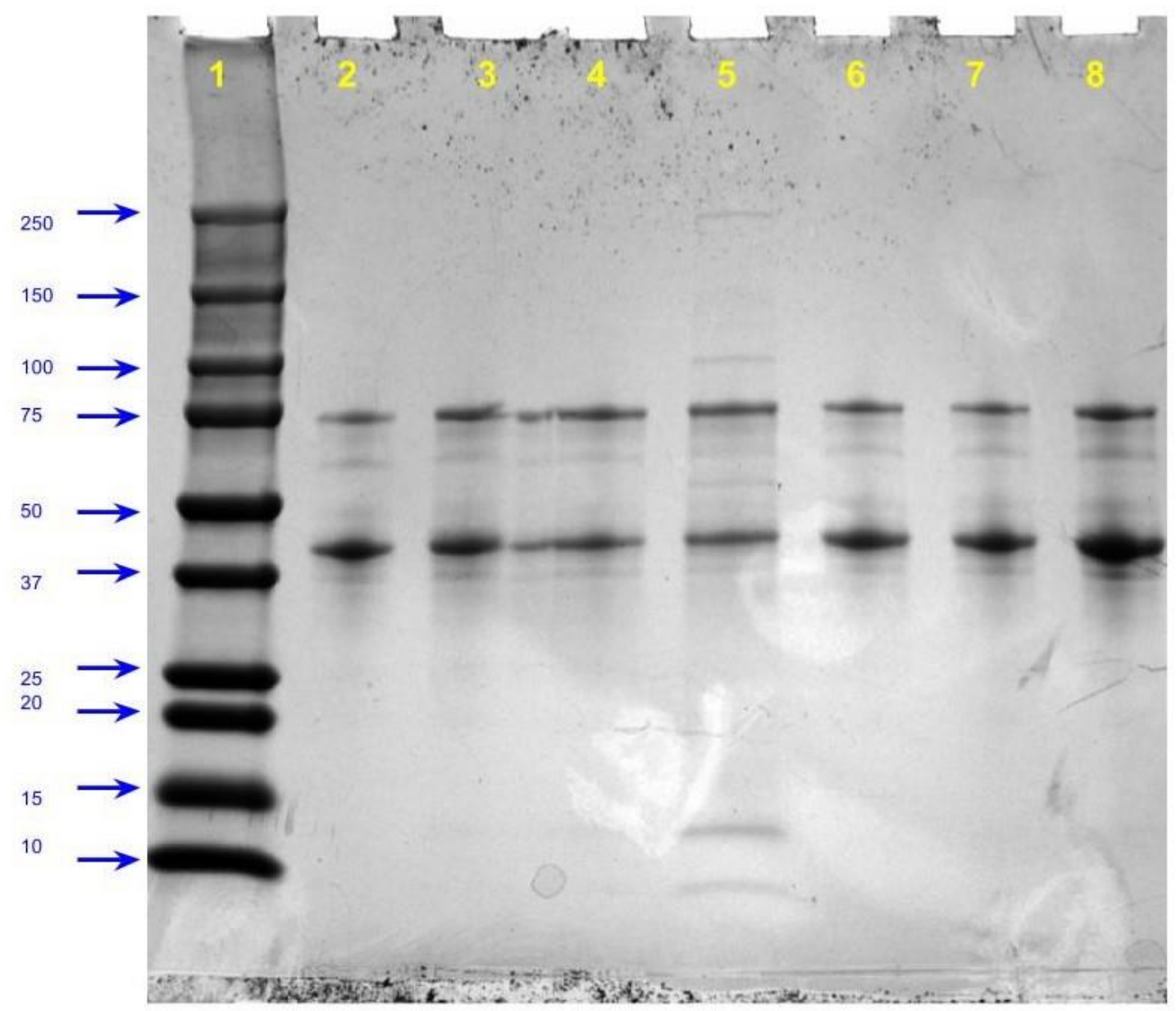

Figure 4.1. Trial 1 filtrate samples run on SDS-PAGE (4-20\% gel) visualized with Coomassie staining. Lane 1. Protein Standard; Lane 2. $0 \%$ NaCl, pH of 5.2; Lane 3. 0.5\% NaCl, pH of 5.2; Lane 4. 1\% NaCl, pH of 5.2; Lane 5. 2.5\% NaCl, pH 5.2; Lane 6. 0\% NaCl, pH of 4.6; Lane 7. $0 \% \mathrm{NaCl}$, pH of 4.8; Lane 8. $0 \%$ $\mathrm{NaCl}, \mathrm{pH}$ of 5.0. The molecular sizes of the marker are given in $\mathrm{kDa}$. 


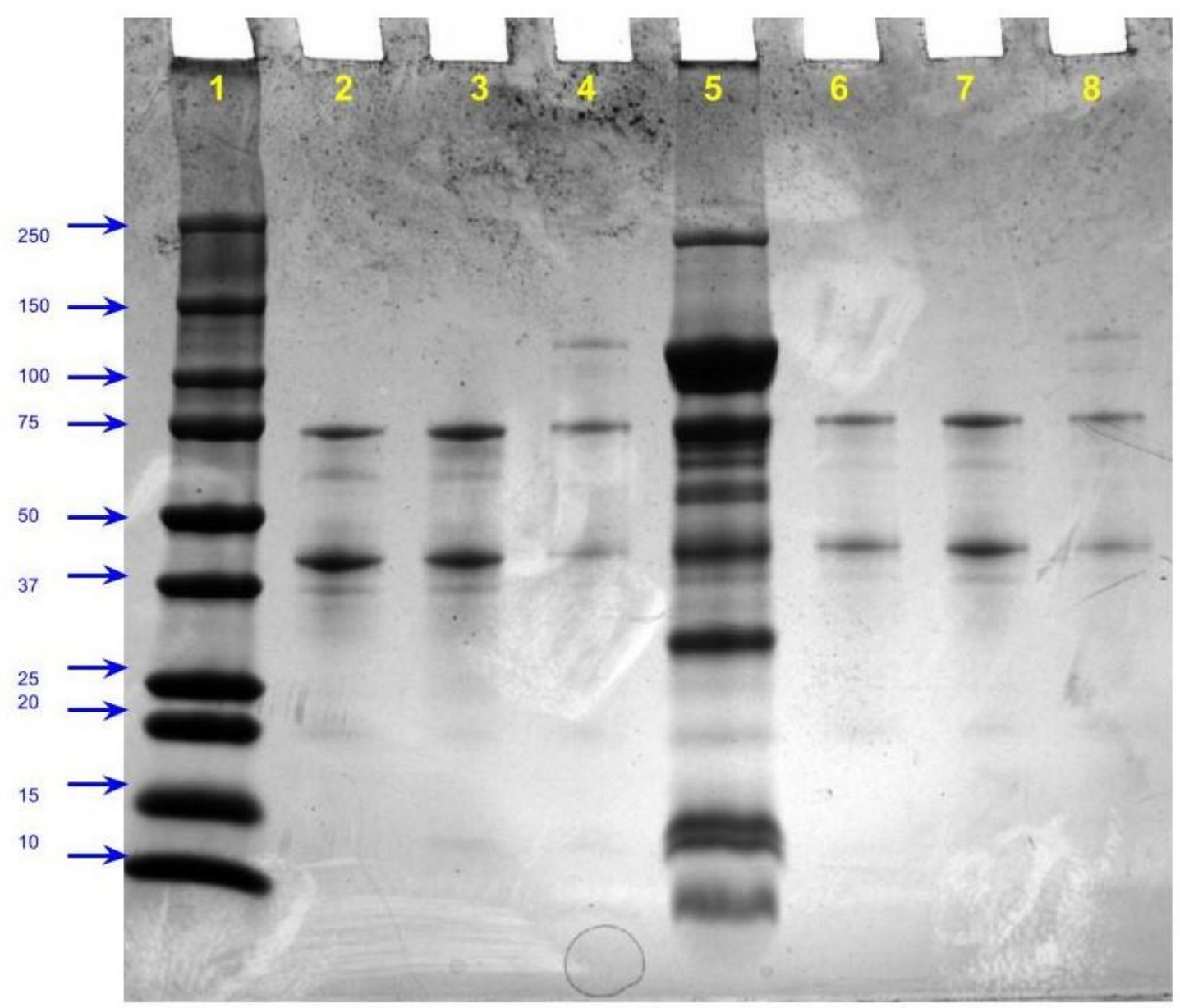

Figure 4.2. Trial 2 filtrate samples run on SDS-PAGE (4-20\% gel) visualized with Coomassie staining. Lane 1. Protein Standard; Lane 2. $0 \% \mathrm{NaCl}$, pH of 5.2; Lane 3. 0.5\% NaCl, pH of 5.2; Lane 4. $1 \% \mathrm{NaCl}$, pH of 5.2; Lane 5. 2.5\% NaCl, pH 5.2; Lane 6. $0 \% \mathrm{NaCl}$, pH of 4.6; Lane 7. $0 \% \mathrm{NaCl}$, pH of 4.8; Lane 8. $0 \%$ $\mathrm{NaCl}, \mathrm{pH}$ of 5.0. The molecular sizes of the marker are given in $\mathrm{kDa}$. 


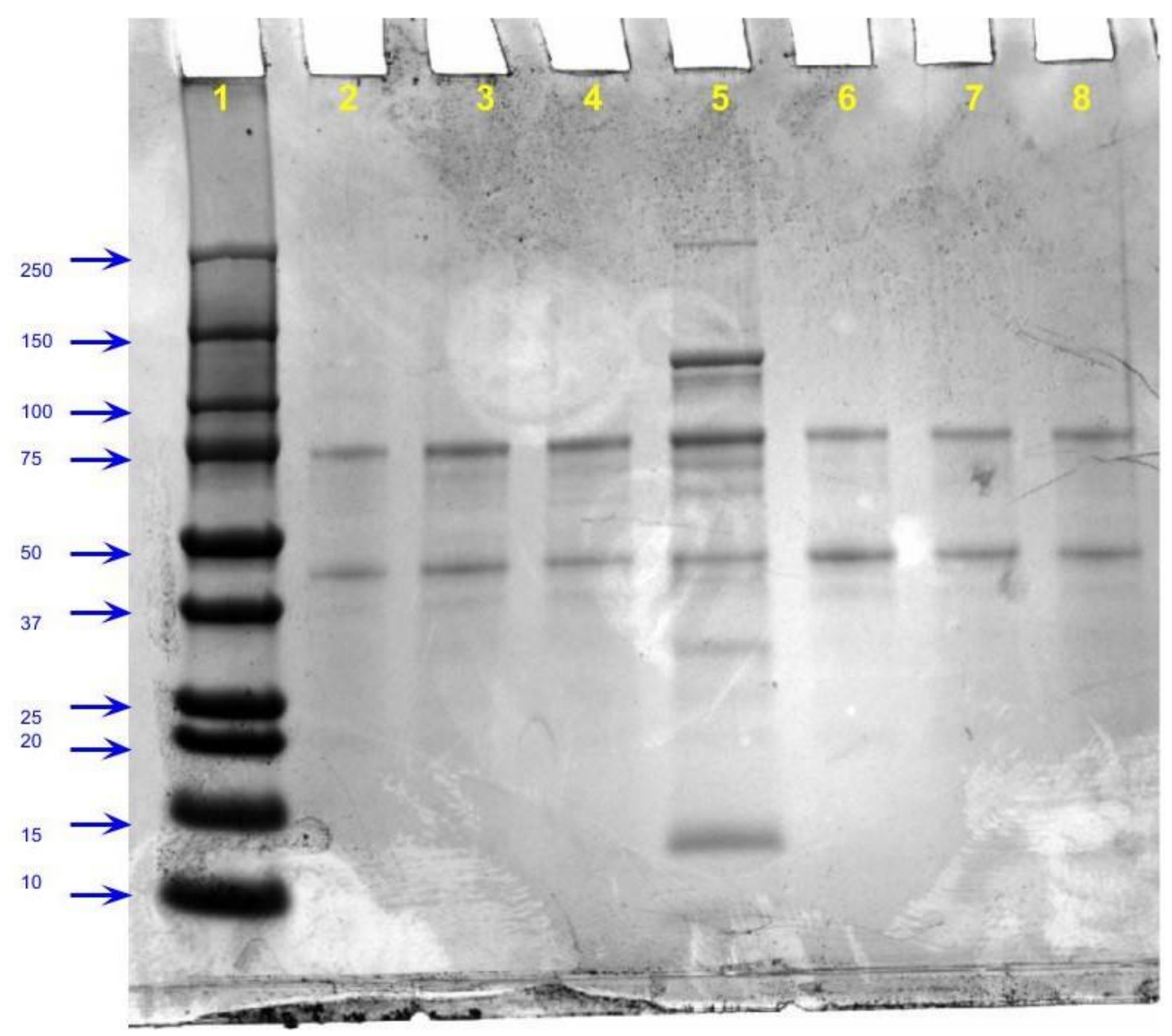

Figure 4.3. Trial 3 filtrate samples run on SDS-PAGE (4-20\% gel) visualized with Coomassie staining. Lane 1. Protein Standard; Lane 2. 0\% NaCl, pH of 5.2; Lane 3. 0.5\% NaCl, pH of 5.2; Lane 4. 1\% NaCl, pH of 5.2; Lane 5. 2.5\% NaCl, pH 5.2; Lane 6. $0 \% \mathrm{NaCl}$, pH of 4.6; Lane 7. $0 \% \mathrm{NaCl}$, pH of 4.8; Lane 8. $0 \%$ $\mathrm{NaCl}, \mathrm{pH}$ of 5.0. The molecular sizes of the marker are given in $\mathrm{kDa}$. 


\subsubsection{Protein Quantification}

Total amounts of crude protein in the yellow cake samples after filtration and preparation (with centrifugation) were analyzed using a Thermo Scientific Pierce BCA Protein Assay kit (Rockford, IL). The BCA method was chosen over the Biuret, Lowry, and Bradford methods because of its higher sensitivity and lower variability. Sample preparations from trials 1-3 were run both with a 1:9 dilution and undiluted. The undiluted data all fell within the working range and was subsequently used for analysis, as well as for standardization for the MIC procedure.

After centrifugation, a small milky yellow sediment formed on the bottom of the falcon tubes, with the exception of the sample with $2.5 \% \mathrm{NaCl}$. This tube formed a yellow pellicle on the top of the tube. The tubes with $1 \% \mathrm{NaCl}$ had small floating light yellow particles suspended in solution. The supernatant was then prepared and analyzed with BCA.

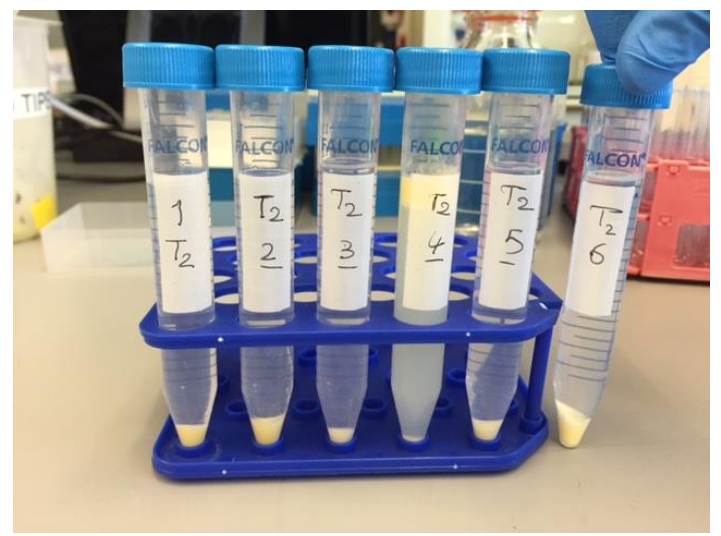

Figure 4.4 Sediment formed on bottom of centrifuged samples. From right to left: $\mathrm{pH}$ 5.2: $0 \% \mathrm{NaCl}, 0.5 \% \mathrm{NaCl}, 1 \% \mathrm{NaCl}, 2.5 \% \mathrm{NaCl} .0 \% \mathrm{NaCl}$ : pH 4.6, pH 4.8. Pellicle formed on trial with $2.5 \% \mathrm{NaCl}$ 


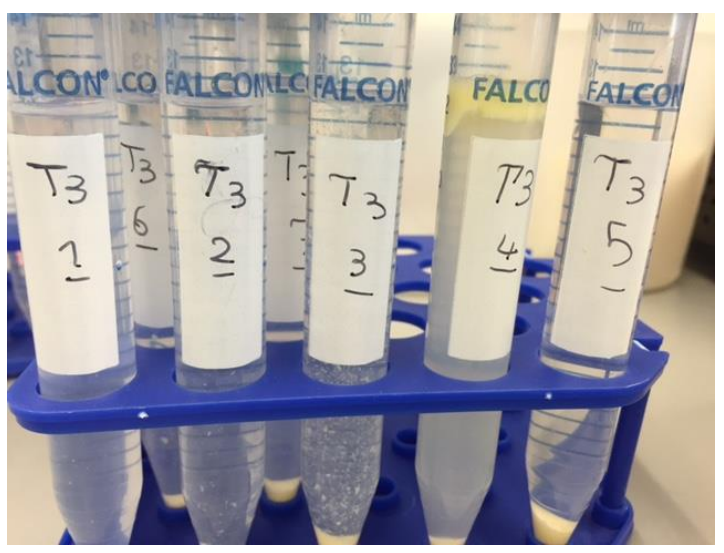

Figure 4.5 From right to left: pH 5.2: $0 \% \mathrm{NaCl}, 0.5 \% \mathrm{NaCl}, 1 \% \mathrm{NaCl}, 2.5 \%$ NaCl. 0\% NaCl: pH 4.6 Floating particles in tube with $1 \%$ salt

A protein standard of bovine serum albumin (BSA) was used as reference to determine unknown protein amounts. The microplate procedure was used to run the samples and standards. After running the samples in the spectrometer at $562 \mathrm{~nm}$, the unknown sample protein amounts were determined based on the standard curve. 
Table 4.1 Averaged protein concentration from BCA after treatments

\begin{tabular}{|c|c|c|c|}
\hline Trial number & Salt Conc \% & pH & Avg Protein Conc in ug/ml \\
\hline 1 & 0 & 5.2 & 692 \\
\hline 1 & 0.5 & 5.2 & 776 \\
\hline 1 & 1 & 5.2 & 532 \\
\hline 1 & $2.50 \%$ & 5.2 & 985 \\
\hline 1 & 0 & 4.6 & 730 \\
\hline 1 & 0 & 4.8 & 691 \\
\hline 1 & 0 & 5 & 1265 \\
\hline 2 & 0 & 5.2 & 669 \\
\hline 2 & 0.5 & 5.2 & 763 \\
\hline 2 & 1 & 5.2 & 388 \\
\hline 2 & $2.50 \%$ & 5.2 & 3051 \\
\hline 2 & 0 & 4.6 & 306 \\
\hline 2 & 0 & 4.8 & 537 \\
\hline 2 & 0 & 5 & 221 \\
\hline 3 & 0 & 5.2 & 283 \\
\hline 3 & 0.5 & 5.2 & 518 \\
\hline 3 & 1 & 5.2 & 401 \\
\hline 3 & $2.50 \%$ & 5.2 & 1468 \\
\hline 3 & 0 & 4.6 & 429 \\
\hline 3 & 0 & 4.8 & 281 \\
\hline 3 & 0 & 5 & 284 \\
\hline
\end{tabular}

The results for the different levels of $\mathrm{NaCl}$ effect on protein concentration did show that $\mathrm{NaCl}$ concentration had a statistical significance, as salt concentration had a pvalue $<0.05$. Overall, there was a noticeable trend of higher protein concentrations with the addition of salt. However, data showed there was a small decrease with $1 \%$ salt, which could be due to a few reasons. It is likely the suspended particles present in the $1 \%$ salt samples interfered with the BCA analysis, giving an inaccurate reading. If there was no interference, there could be a salting in effect on the protein. The increase at $2.5 \%$ is likely due to the disruption of the granules, solubilizing phosvitin 
and HDL (Huopalahti et al., 2007). At this concentration, the phosphocalcic bridges would break with sodium replacement of calcium. The free phosvitin would solubilize because of the salt concentration. At a concentration at $2.5 \% \mathrm{NaCl}$, the most protein is extracted, as well as more types of proteins, as shown from the previous section in the gels. Figure 4.6 visualizes the effect of $\mathrm{NaCl}$ on protein concentration.

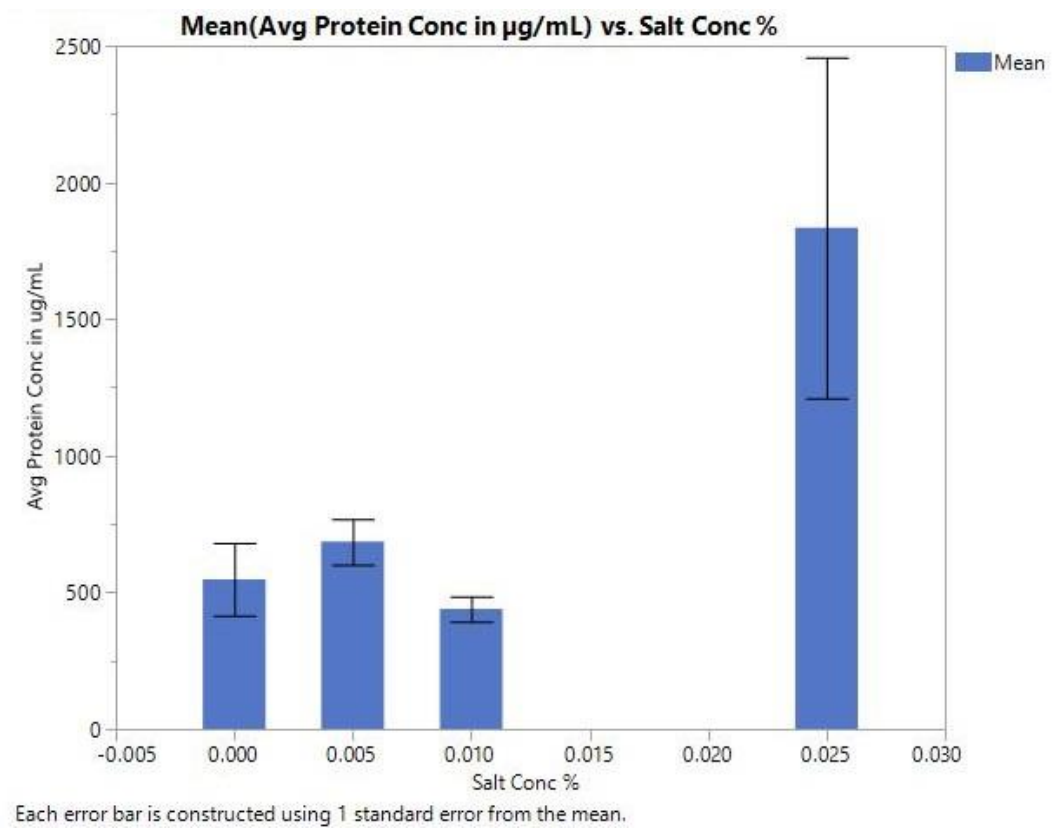

Figure 4.6 Effect of $\mathrm{NaCl}$ on protein concentration

The results in the $\mathrm{pH}$ range of 4.6-5.2 did not prove to be statistically significant. There is no evidence that $\mathrm{pH}$ adjustments within this range have an effect on the protein concentration. Figure 4.7 visualizes the effect of $\mathrm{pH}$ on protein concentration. 


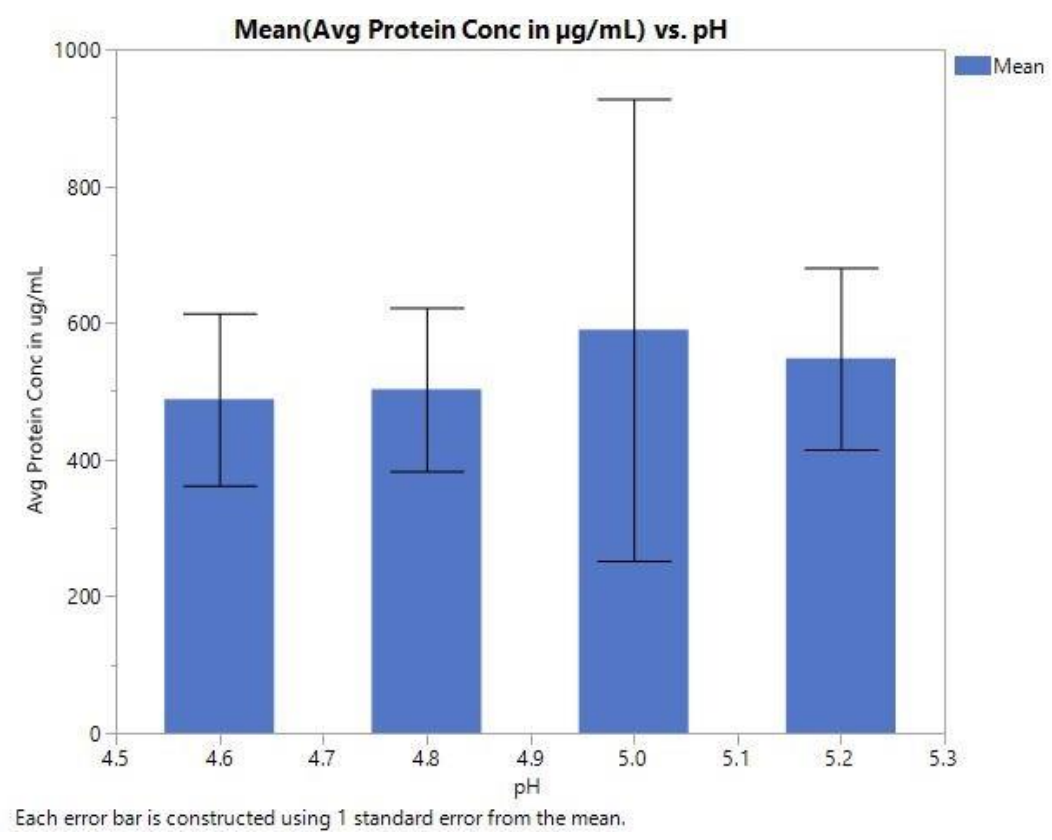

Figure 4.7 Effect of $\mathrm{pH}$ on protein concentration

\subsection{Precipitation}

\subsubsection{Observations of addition of $\mathrm{NaCl}$}

Lab scale samples of yellow cake were diluted in water to make a 5\% solids solution. After adjusting the solution to samples of 5 different salt concentrations and the first round of centrifugation, a gelatinous pellicle formed on the top of the solution. At $3 \%$ $\mathrm{NaCl}$ content, there were visible puffy light yellow clumps and strands floating just below the pellicle. At $4 \%$ and $5 \% \mathrm{NaCl}$, there were less clumps hanging attached to the bottom of the pellicle layer. $\mathrm{By} 6 \% \mathrm{NaCl}$, there appeared to be complete separation, as well as 7\%. This is shown in figures 4.8-4.12. 


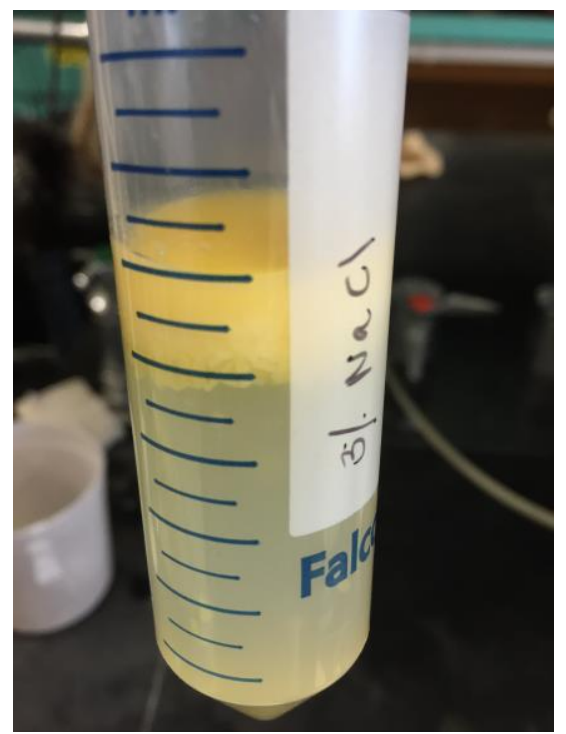

Figure 4.8 3\% NaCl Solution

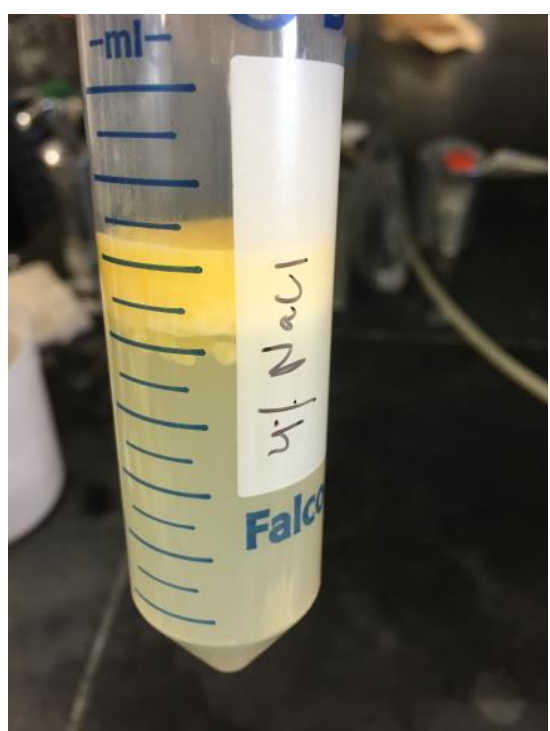

Figure 4.9 4\% NaCl Solution

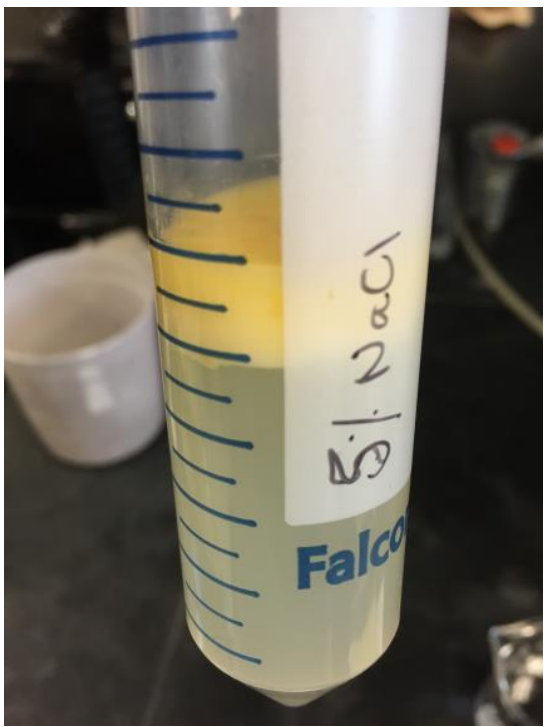

Figure 4.10 5\% NaCl Solution 


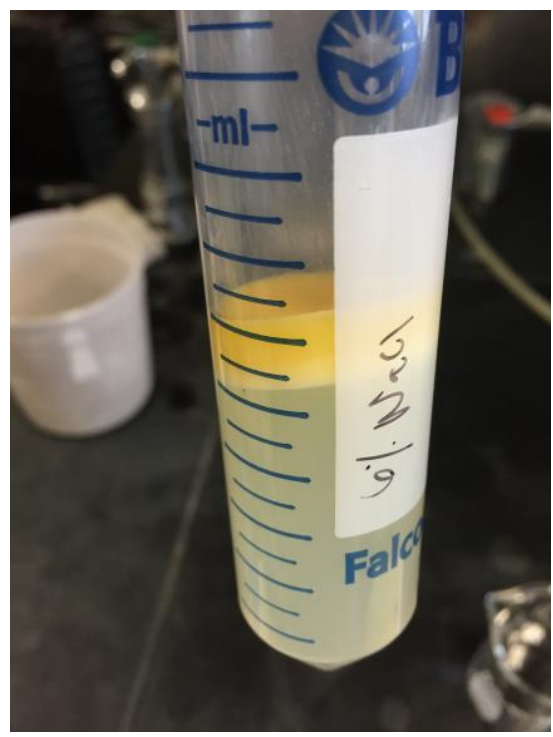

Figure 4.11 6\% NaCl Solution

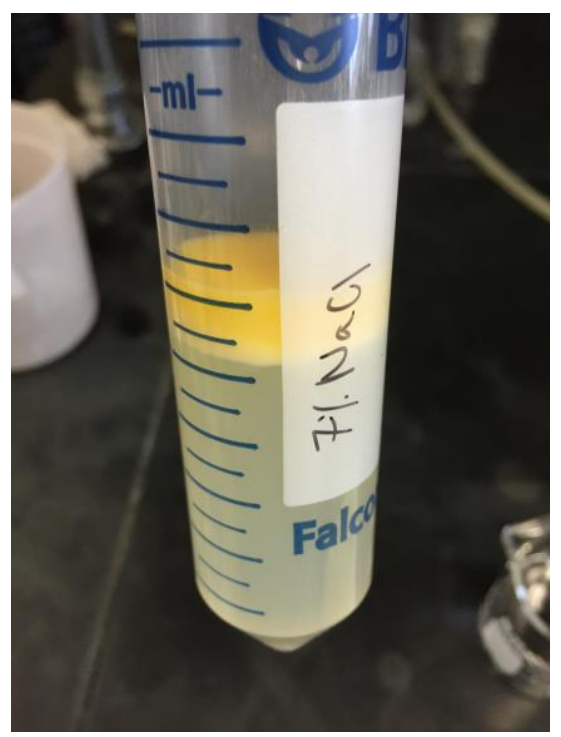

Figure 4.12 7\% NaCl Solution

The adjustment of density with addition of salt allowed the insoluble yellow layer to invert and form a pellicle on top. At $3 \% \mathrm{NaCl}$, the pellicle was less compact with strands attached to it, as well as a more turbid water-soluble portion. By the concentration of $6 \% \mathrm{NaCl}$, the pellicle on top was compacted with no floating particles beneath it.

After addition of $\mathrm{HCl}$ and centrifugation, firm white pellets precipitated on the bottom of the falcon tubes. In an industry scale extraction, this simple inversion, followed by precipitation could make the process more efficient. When collecting the water soluble protein fraction, it could be easily emptied from the bottom of the tank, then run through a centrifuge or separator, and then the protein pellet collected. This eliminates a more complicated process of siphoning and pumping the water soluble fraction out when it is the floating layer on top. 


\subsubsection{Protein Content}

SDS-PAGE was used to profile the proteins contained in the reconstituted pellet from the precipitation experiment. Samples were subjected to and analyzed under ten different conditions, considering two variables: $\mathrm{NaCl}$ content and temperature. After diluting samples, gels were run accordingly, taking care that the tracking dye did not travel farther than the bottom of the gels. Gels were stained using Coomassie Brilliant Blue to view the bands.

Figure 4.13 illustrates the protein content in the supernatant from the precipitation experiment. These samples are the result of the procedure illustrated in diagram 3.7. Lane 1 represents the protein standard. Lane 2 represents $3 \% \mathrm{NaCl}$ incubated at room temperature (RT). Lane 3 represents $4 \% \mathrm{NaCl}$ incubated at $\mathrm{RT}$. Lane 4 represents $5 \%$ $\mathrm{NaCl}$ incubated at $\mathrm{RT}$. Lane 5 represents $6 \% \mathrm{NaCl}$ incubated at $\mathrm{RT}$. Lane 6 represents $7 \% \mathrm{NaCl}$ incubated at $\mathrm{RT}$. Lane 7 represents $4 \% \mathrm{NaCl}$ incubated at $4^{\circ} \mathrm{C}$. Lane 8 represents $5 \% \mathrm{NaCl}$ incubated at $4{ }^{\circ} \mathrm{C}$. Lane 9 represents $6 \% \mathrm{NaCl}$ incubated at $4{ }^{\circ} \mathrm{C}$. Lane 10 represents $7 \% \mathrm{NaCl}$ incubated at $4{ }^{\circ} \mathrm{C}$.

The same migration pattern appeared across all sample treatments for the precipitation treatments. Bands ranged from $10 \mathrm{kDa}$ to $250 \mathrm{kDa}$. The largest, prominent band appeared at $\sim 125 \mathrm{kDa}$ as diffuse band. Smaller bands appeared under it in the $100-125 \mathrm{kDa}$ range. There were more prominent bands at $\sim 74, \sim 45, \sim 35$, and $\sim 29 \mathrm{kDa}$. The addition of salt at this range did not affect the different proteins 
solubilized. It is likely that the granules are already completed disrupted at a concentration at $2.5 \%$.

The band at $125 \mathrm{kDa}$ is likely apoprotein of LDL (Awade 1995; Zambrowicz et al., 2014). At 100-125, 74, 28 and $45 \mathrm{kDa}$, the bands are likely polypeptides of HDL (Awade 1995; Zambrowicz et al., 2014; Strixner and Kulozik, 2013). It is possible the $\sim 35$ marker is $\beta$-livetin, if there was some leftover from the plasma fraction, but not likely.

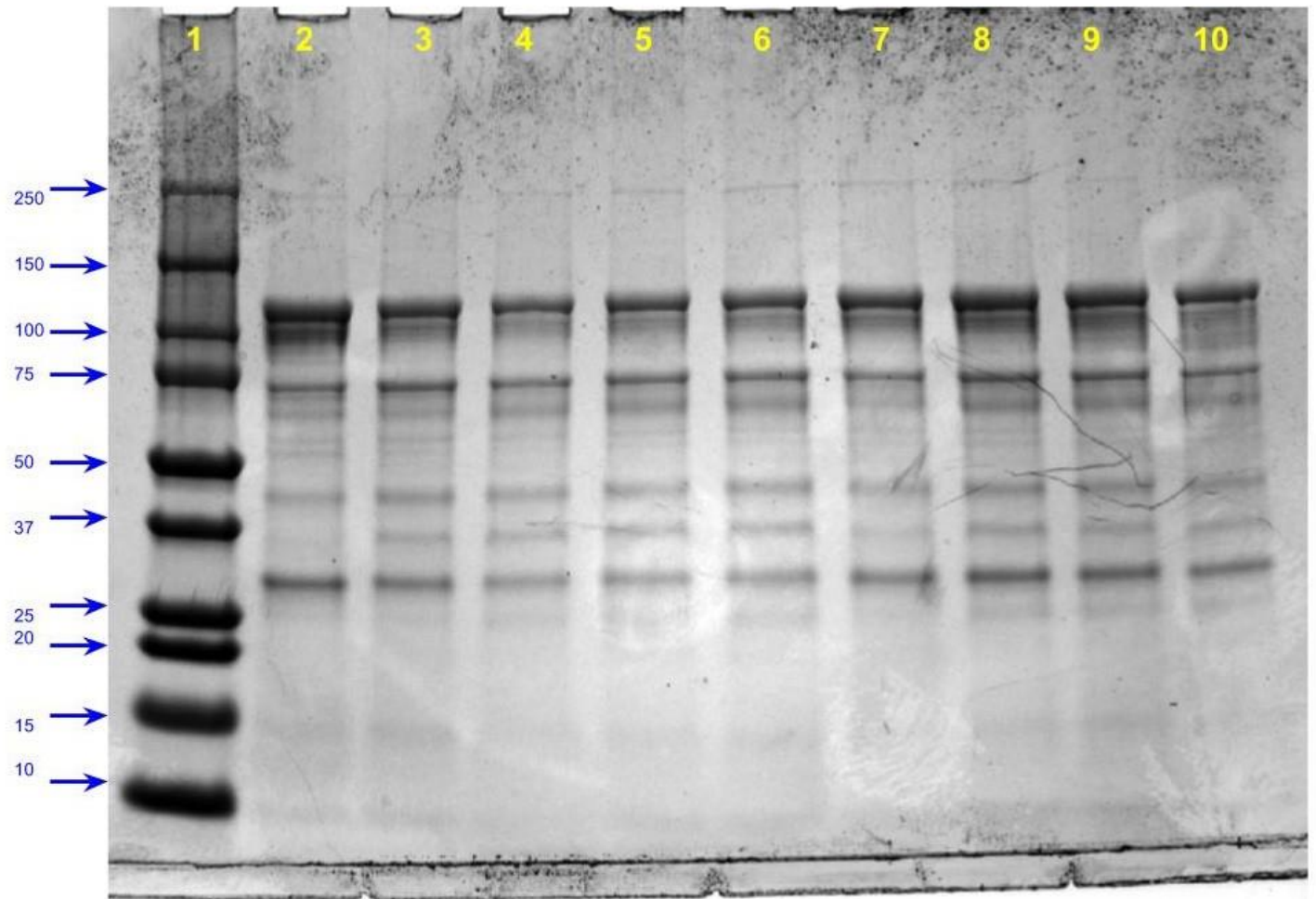

Figure 4.13 Precipitation samples run on SDS-PAGE (4-20\% gel) visualized with Coomassie staining. Lane 1. Protein Standard; Lane 2. 3\% NaCl, room temperature (RT); Lane 3. 4\% NaCl, RT; Lane 4. 5\% NaCl, RT; Lane 5. $6 \%$ $\mathrm{NaCl}$, RT; Lane 6. 7\% NaCl, RT; Lane 7. $4 \% \mathrm{NaCl}, 4^{\circ} \mathrm{C}$; Lane $8.5 \% \mathrm{NaCl}, 4^{\circ} \mathrm{C}$; Lane 9. $6 \% \mathrm{NaCl}, 4^{\circ} \mathrm{C}$; Lane $10.7 \% \mathrm{NaCl}, 4^{\circ} \mathrm{C}$. The molecular sizes of the marker are given in $\mathrm{kDa}$. 


\subsection{MIC}

Three plates, one from trial 1, 2, and 3, were assayed without proteolysis. Crude protein was standardized to $256 \mu \mathrm{g} / \mathrm{mL}$ in MHB and diluted according to procedure. After 20 hours of incubation at $37^{\circ} \mathrm{C}$, growth $/$ no growth was observed. The test results for the MIC procedure are based on a growth/no growth response to find the lowest concentration of proteins to inhibit the growth of bacteria. Although the results

did not conclusively show a minimum inhibitory concentration, the patterns are worth examining for potential insight about the possible antibacterial properties of the protein extract.

\subsubsection{No Proteolysis}

For Trial 1, there was no growth in any of the wells in the control columns 11 and 12. For column 10 with just $E$. coli and broth, there was growth in all cells in the column. This confirms the MHB and the protein were not contaminated, and that the E. coli was present in sufficient amount. There were no other wells with zero growth, however all wells in columns 1 and 2 with higher protein concentrations showed less turbidity, implying less growth.

For Trial 2, there was no growth in all wells in column 12 or in column 11 wells B,C, and D. This shows there may have been some contamination of the protein samples for this trial. There was were no other wells with zero growth. Like Trial 1, columns 1 and 2 were less turbid, as well as wells 5C and 5D. 
For Trial 3, there was slight growth in column 11, and no growth in column 12 . There may have also been some slight contamination in the protein from this trial. All other wells in all columns had similar turbidity throughout. 


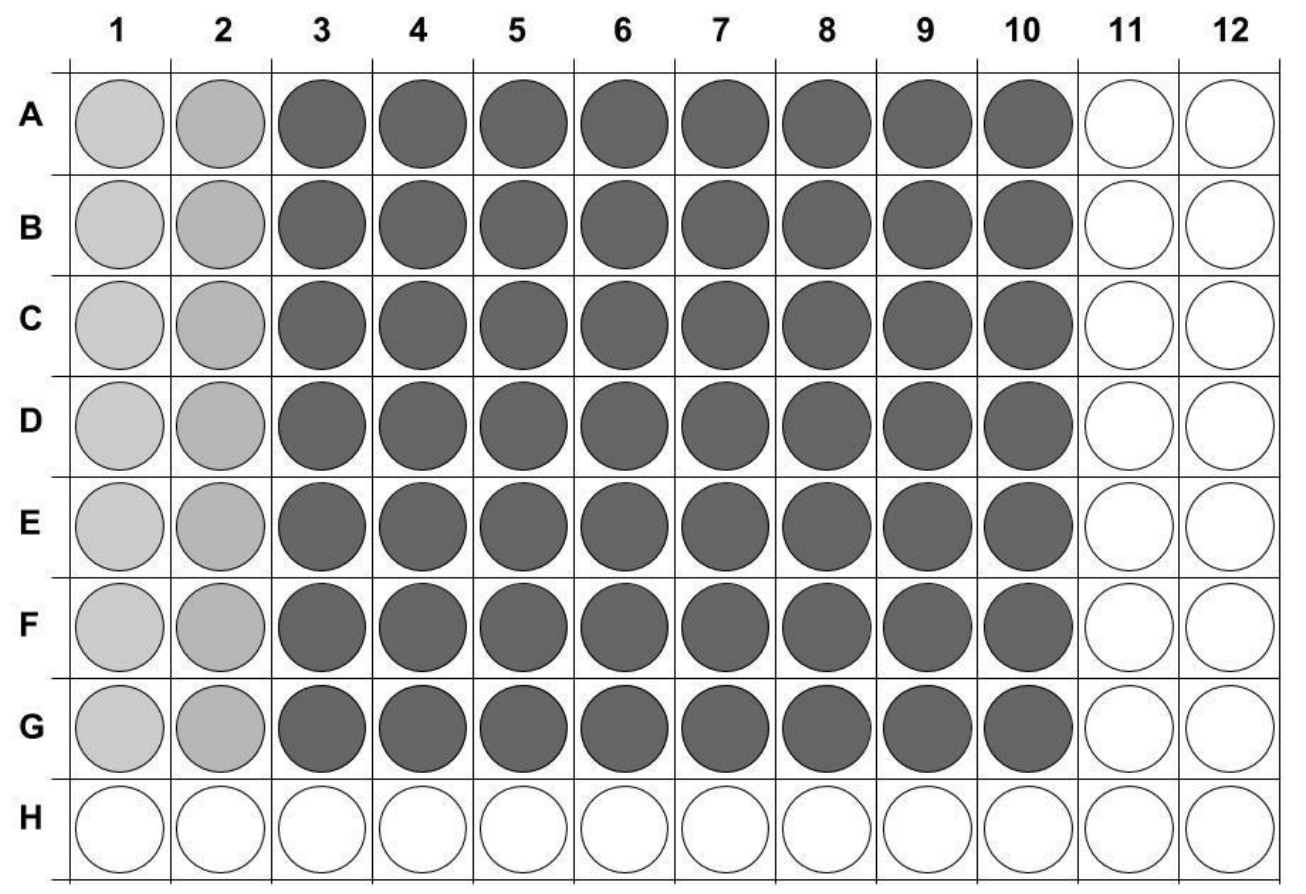

Figure 4.14 Trial 1 MIC with no proteolysis

Row A: $0.0 \% \mathrm{NaCl}, \mathrm{pH}=5.2$

Row B: $0.5 \% \mathrm{NaCl}, \mathrm{pH}=5.2$

Row C: $1.0 \% \mathrm{NaCl}, \mathrm{pH}=5.2$

Row D: $2.5 \% \mathrm{NaCl}, \mathrm{pH}=5.2$

Row E: $0.0 \% \mathrm{NaCl}, \mathrm{pH}=4.6$

Row F: $0.0 \% \mathrm{NaCl}, \mathrm{pH}=4.8$

Row G: $0.0 \% \mathrm{NaCl}, \mathrm{pH}=5.0$

Row $\mathrm{H}$ is empty

Protein Concentrations in MHB inoculated with E. coli:

Column 1: $256 \mu \mathrm{g} / \mathrm{mL}$

Column 2: $128 \mu \mathrm{g} / \mathrm{mL}$

Column 3: $64 \mu \mathrm{g} / \mathrm{mL}$

Column 4: $32 \mu \mathrm{g} / \mathrm{mL}$

Column 5: $16 \mu \mathrm{g} / \mathrm{mL}$

Column 6: $8 \mu \mathrm{g} / \mathrm{mL}$

Column 7: $4 \mu \mathrm{g} / \mathrm{mL}$

Column 8: $2 \mu \mathrm{g} / \mathrm{mL}$

Column 9: $1 \mu \mathrm{g} / \mathrm{mL}$

Controls:

Column 10: E. coli and MHB

Column 11: $256 \mu \mathrm{g} / \mathrm{mL}$ protein solution in MHB

Column 12: MHB 


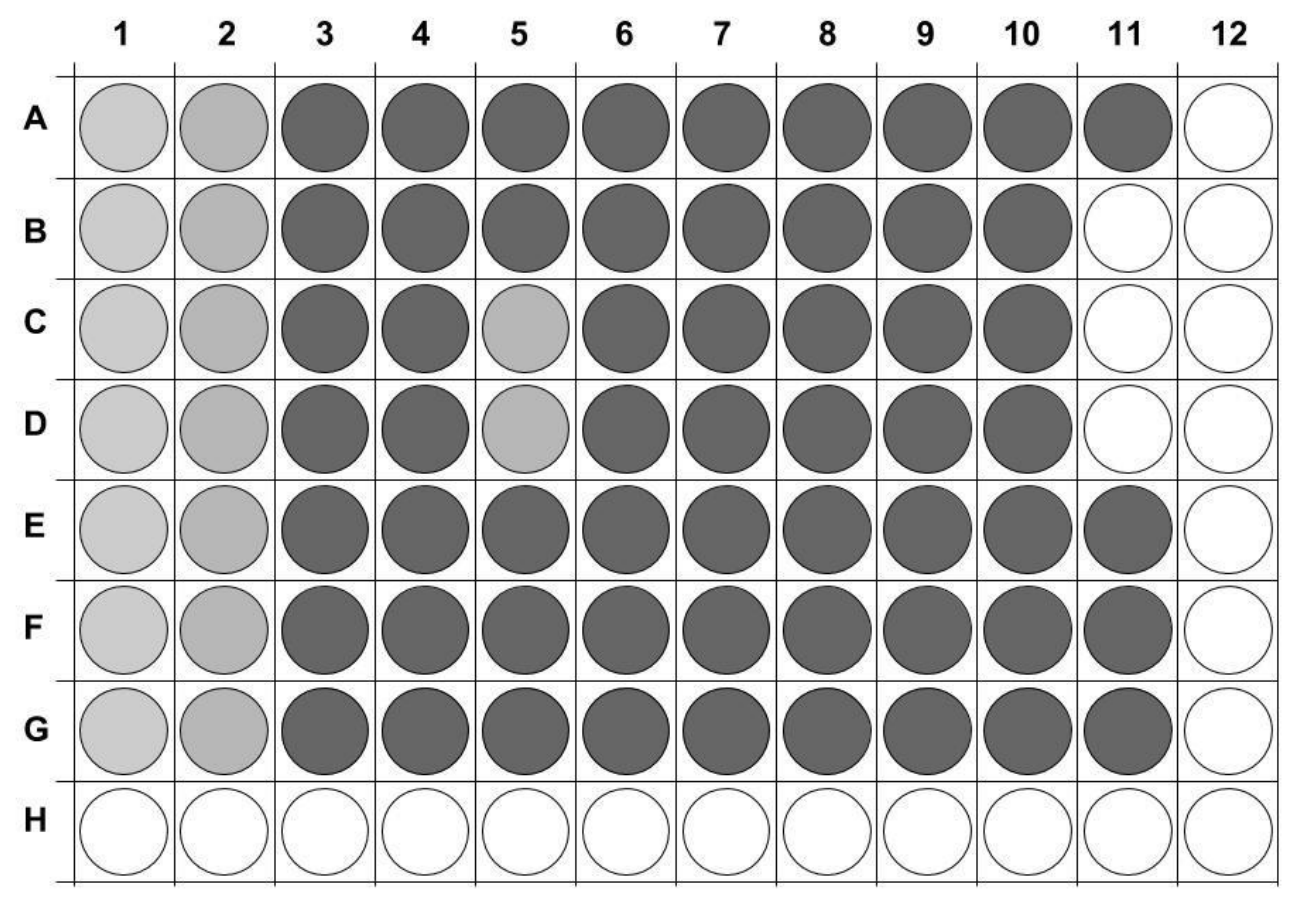

Figure 4.15 Trial $2 \mathrm{MIC}$ with no proteolysis

Row A: $0.0 \% \mathrm{NaCl}, \mathrm{pH}=5.2$

Row B: $0.5 \% \mathrm{NaCl}, \mathrm{pH}=5.2$

Row C: $1.0 \% \mathrm{NaCl}, \mathrm{pH}=5.2$

Row D: $2.5 \% \mathrm{NaCl}, \mathrm{pH}=5.2$

Row E: $0.0 \% \mathrm{NaCl}, \mathrm{pH}=4.6$

Row F: $0.0 \% \mathrm{NaCl}, \mathrm{pH}=4.8$

Row $\mathrm{G}$ : $0.0 \% \mathrm{NaCl}, \mathrm{pH}=5.0$

Row $\mathrm{H}$ is empty

Protein Concentrations in MHB inoculated with E. coli:

Column 1: $256 \mu \mathrm{g} / \mathrm{mL}$

Column 2: $128 \mu \mathrm{g} / \mathrm{mL}$

Column 3: $64 \mu \mathrm{g} / \mathrm{mL}$

Column 4: $32 \mu \mathrm{g} / \mathrm{mL}$

Column 5: $16 \mu \mathrm{g} / \mathrm{mL}$

Column 6: $8 \mu \mathrm{g} / \mathrm{mL}$

Column 7: $4 \mu \mathrm{g} / \mathrm{mL}$

Column 8: $2 \mu \mathrm{g} / \mathrm{mL}$

Column 9: $1 \mu \mathrm{g} / \mathrm{mL}$

Controls:

Column 10: E. coli and MHB

Column 11: $256 \mu \mathrm{g} / \mathrm{mL}$ protein solution in MHB

Column 12: MHB 


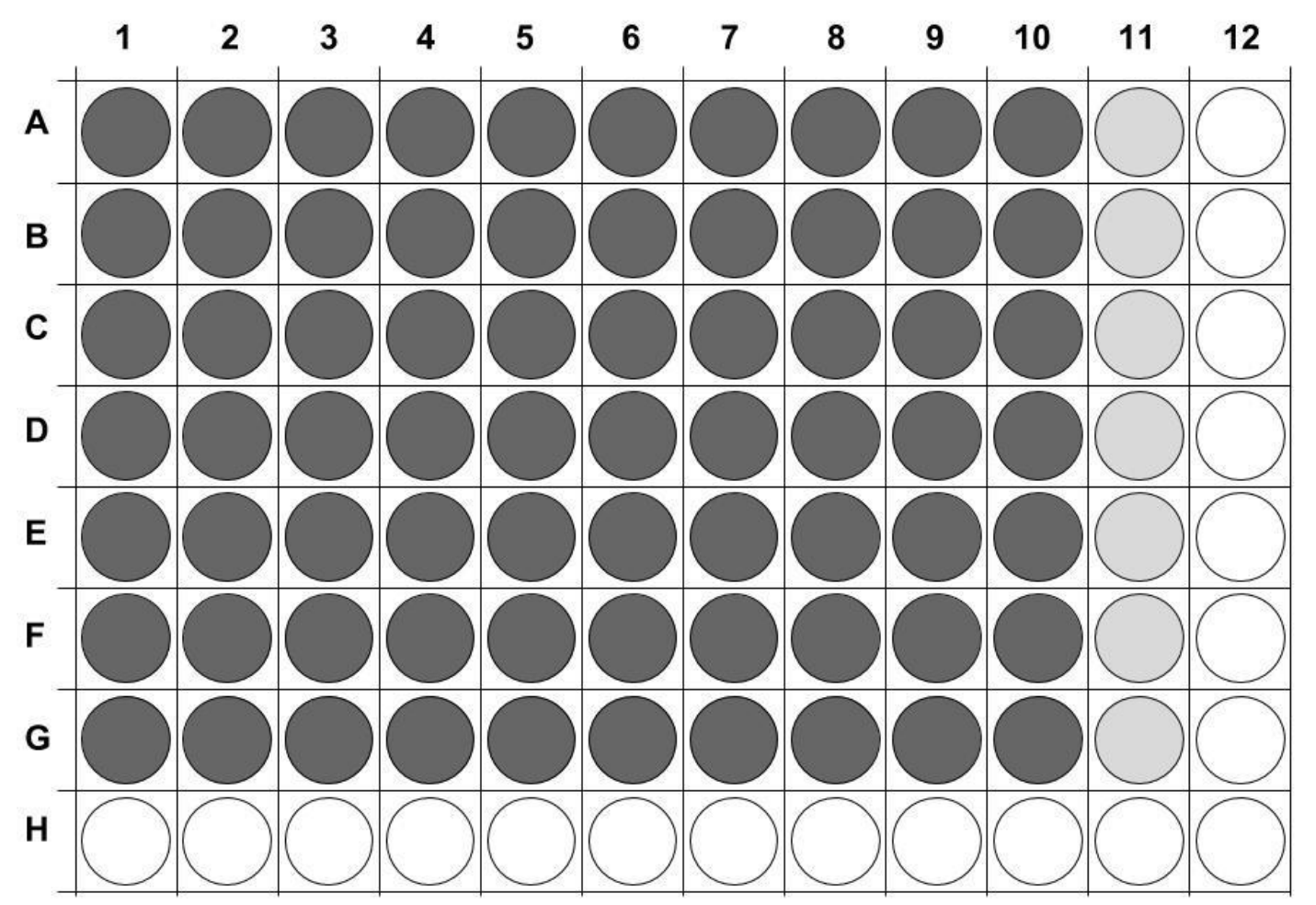

Figure 4.16 Trial 3 MIC with no proteolysis

Row A: $0.0 \% \mathrm{NaCl}, \mathrm{pH}=5.2$

Row B: $0.5 \% \mathrm{NaCl}, \mathrm{pH}=5.2$

Row C: $1.0 \% \mathrm{NaCl}, \mathrm{pH}=5.2$

Row D: $2.5 \% \mathrm{NaCl}, \mathrm{pH}=5.2$

Row E: $0.0 \% \mathrm{NaCl}, \mathrm{pH}=4.6$

Row F: $0.0 \% \mathrm{NaCl}, \mathrm{pH}=4.8$

Row G: $0.0 \% \mathrm{NaCl}, \mathrm{pH}=5.0$

Row $\mathrm{H}$ is empty

Protein Concentrations in MHB inoculated with E. coli:

Column 1: $256 \mu \mathrm{g} / \mathrm{mL}$

Column 2: $128 \mu \mathrm{g} / \mathrm{mL}$

Column 3: $64 \mu \mathrm{g} / \mathrm{mL}$

Column 4: $32 \mu \mathrm{g} / \mathrm{mL}$

Column 5: $16 \mu \mathrm{g} / \mathrm{mL}$

Column 6: $8 \mu \mathrm{g} / \mathrm{mL}$

Column 7: $4 \mu \mathrm{g} / \mathrm{mL}$

Column 8: $2 \mu \mathrm{g} / \mathrm{mL}$

Column 9: $1 \mu \mathrm{g} / \mathrm{mL}$

Controls:

Column 10: E. coli and MHB

Column 11: $256 \mu \mathrm{g} / \mathrm{mL}$ protein solution in MHB

Column 12: MHB 


\subsubsection{Proteolysis no endpoint}

Three plates, one from trial 1,2, and 3, were assayed with proteolysis without an endpoint. Crude protein was standardized to $256 \mu \mathrm{g} / \mathrm{mL}$ in a solution of PBS and enzyme solution and then diluted according to procedure. $2.56 \mu \mathrm{L}$ of prepared TrypZean were added to each well of sample and incubated for 2 hours at $37^{\circ} \mathrm{C}$. After 20 hours of incubation at $37^{\circ} \mathrm{C}$, growth/no growth was observed. Figure 4.17-4.19 illustrates the growth patterns.

For Trial 1, there was no growth in column 12 , and there was a very small button appeared down wells in column 11. Wells in column 1 had less turbidity than all other columns. All other columns showed similar turbidity throughout.

For Trial 2, there was no growth in column 12, with a small button in column 11. Wells in column 1 had less turbidity than all other columns. There also appeared to be a gradient of turbidity across the rows. Well D5 also showed hardly any turbidity.

For Trial 3, there was no growth in column 12. Column 11 had no growth in wells D and E, with small button in the rest of the column. The turbidity increased across rows. The gradient that appeared in plates from trial 2 and 3 show a possibility of some bacteriostatic property. Although there is no conclusive evidence in this assay, this gradient appeared most prominently in the plates that had proteolysis without an endpoint. There is a possible release of peptides after addition of TrypZean that may inhibit some $E$. coli growth. The samples with proteolysis with an endpoint did not 
show this pattern, implying that the enzymatic reaction needed more time for digestion. Although this is only speculative because MIC is a growth/no growth test, there are implications for potential bacteriostatic activity in the peptides. 


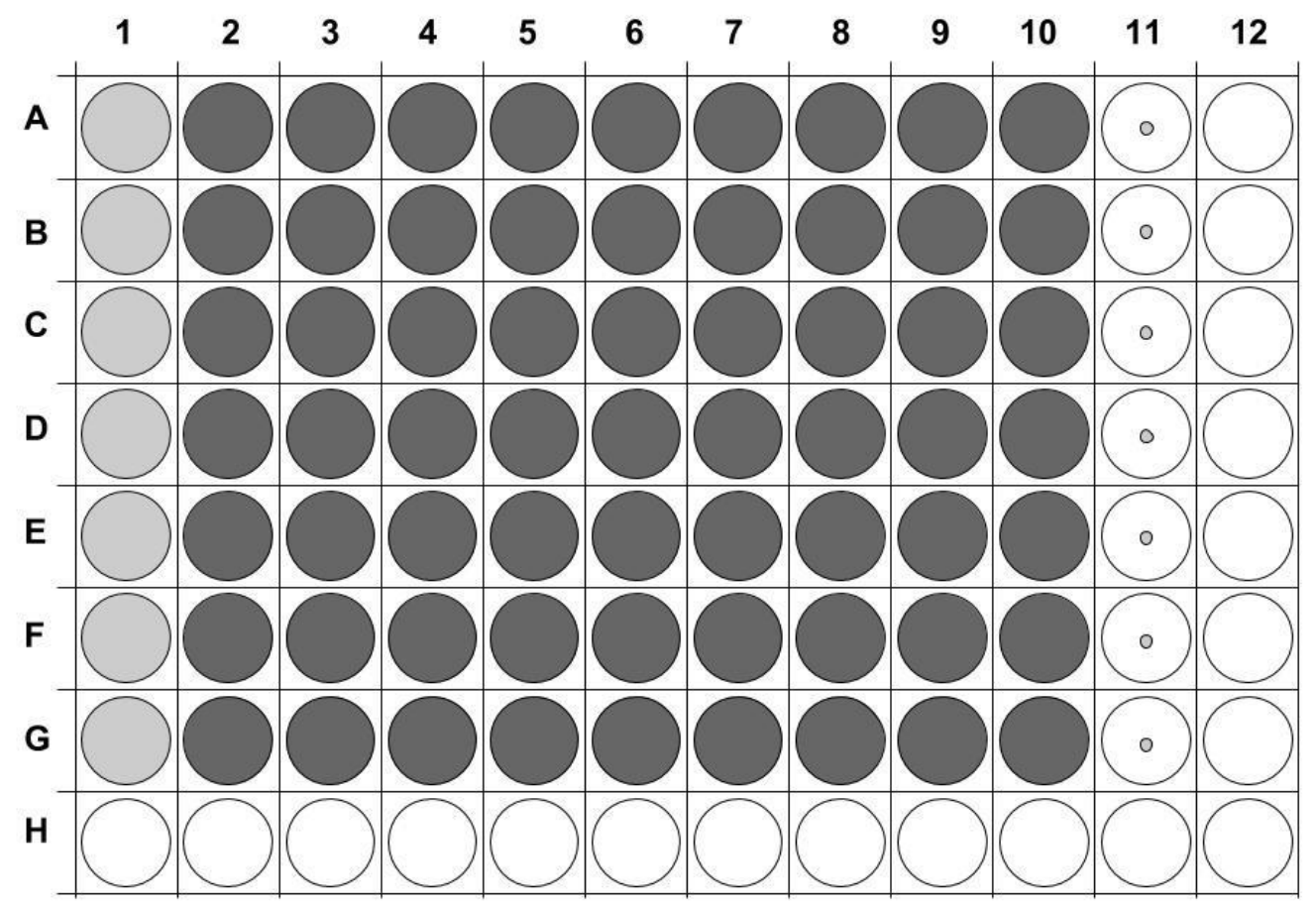

Figure 4.17 Trial $1 \mathrm{MIC}$ with proteolysis with no endpoint

Row A: $0.0 \% \mathrm{NaCl}, \mathrm{pH}=5.2$

Row B: $0.5 \% \mathrm{NaCl}, \mathrm{pH}=5.2$

Row C: $1.0 \% \mathrm{NaCl}, \mathrm{pH}=5.2$

Row D: $2.5 \% \mathrm{NaCl}, \mathrm{pH}=5.2$

Row E: $0.0 \% \mathrm{NaCl}, \mathrm{pH}=4.6$

Row F: $0.0 \% \mathrm{NaCl}, \mathrm{pH}=4.8$

Row $\mathrm{G}: 0.0 \% \mathrm{NaCl}, \mathrm{pH}=5.0$

Row $\mathrm{H}$ is empty

Protein Concentrations in MHB inoculated with E. coli:

Column 1: $256 \mu \mathrm{g} / \mathrm{mL}$

Column 2: $128 \mu \mathrm{g} / \mathrm{mL}$

Column 3: $64 \mu \mathrm{g} / \mathrm{mL}$

Column 4: $32 \mu \mathrm{g} / \mathrm{mL}$

Column 5: $16 \mu \mathrm{g} / \mathrm{mL}$

Column 6: $8 \mu \mathrm{g} / \mathrm{mL}$

Column 7: $4 \mu \mathrm{g} / \mathrm{mL}$

Column 8: $2 \mu \mathrm{g} / \mathrm{mL}$

Column 9: $1 \mu \mathrm{g} / \mathrm{mL}$

Controls:

Column 10: E. coli and MHB + PBS

Column 11: $256 \mu \mathrm{g} / \mathrm{mL}$ protein solution in MHB/TrypZean

Column 12: MHB and PBS 


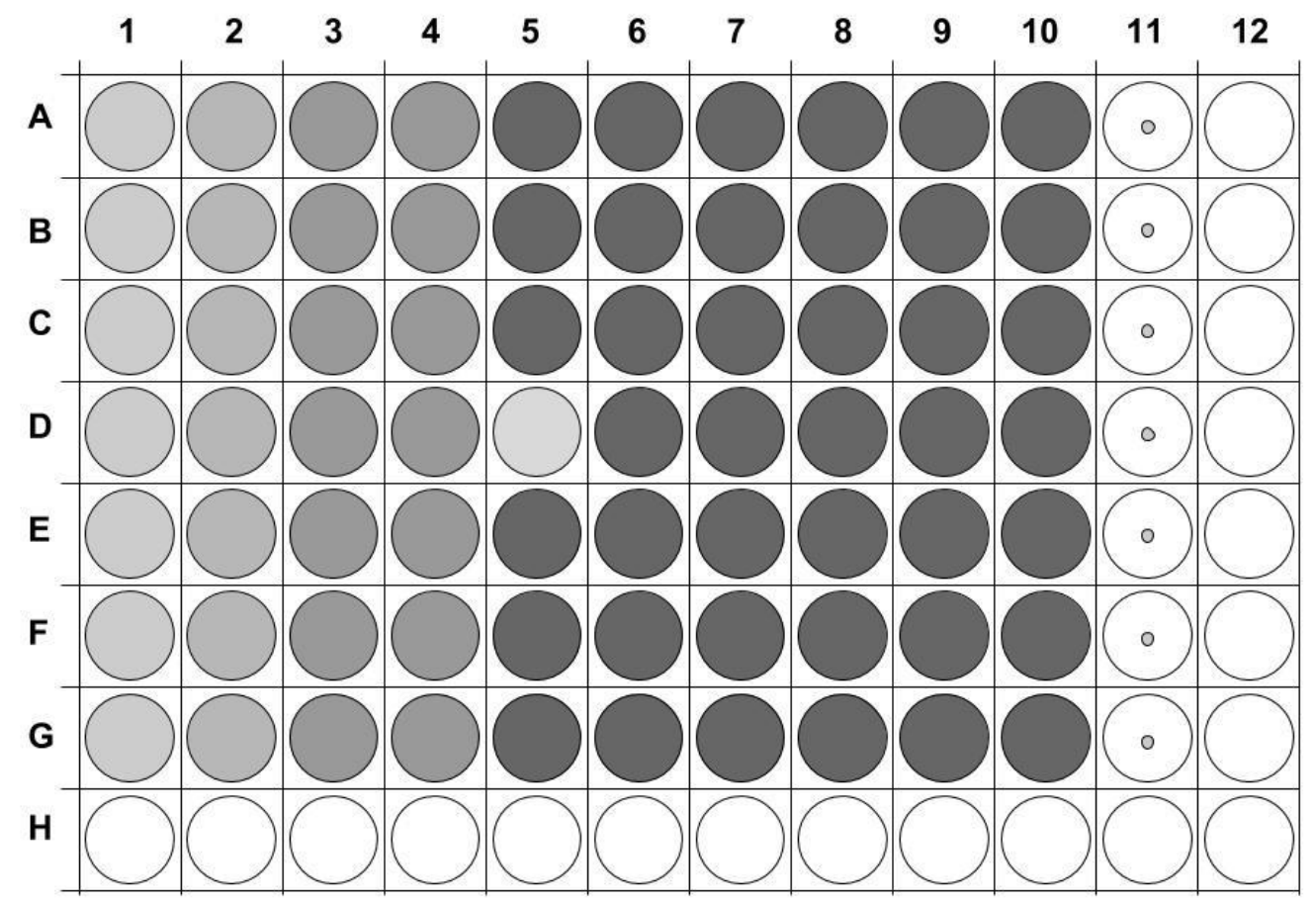

Figure 4.18 Trial 2 MIC with proteolysis with no endpoint

Row A: $0.0 \% \mathrm{NaCl}, \mathrm{pH}=5.2$

Row B: $0.5 \% \mathrm{NaCl}, \mathrm{pH}=5.2$

Row $\mathrm{C}: 1.0 \% \mathrm{NaCl}, \mathrm{pH}=5.2$

Row D: $2.5 \% \mathrm{NaCl}, \mathrm{pH}=5.2$

Row E: $0.0 \% \mathrm{NaCl}, \mathrm{pH}=4.6$

Row F: $0.0 \% \mathrm{NaCl}, \mathrm{pH}=4.8$

Row G: $0.0 \% \mathrm{NaCl}, \mathrm{pH}=5.0$

Row $\mathrm{H}$ is empty

Protein Concentrations in MHB inoculated with E. coli:

Column 1: $256 \mu \mathrm{g} / \mathrm{mL}$

Column 2: $128 \mu \mathrm{g} / \mathrm{mL}$

Column 3: $64 \mu \mathrm{g} / \mathrm{mL}$

Column 4: $32 \mu \mathrm{g} / \mathrm{mL}$

Column 5: $16 \mu \mathrm{g} / \mathrm{mL}$

Column 6: $8 \mu \mathrm{g} / \mathrm{mL}$

Column 7: $4 \mu \mathrm{g} / \mathrm{mL}$

Column 8: $2 \mu \mathrm{g} / \mathrm{mL}$

Column 9: $1 \mu \mathrm{g} / \mathrm{mL}$

Controls:

Column 10: E. coli and MHB + PBS

Column 11: $256 \mu \mathrm{g} / \mathrm{mL}$ protein solution in MHB/TrypZean

Column 12: MHB and PBS 


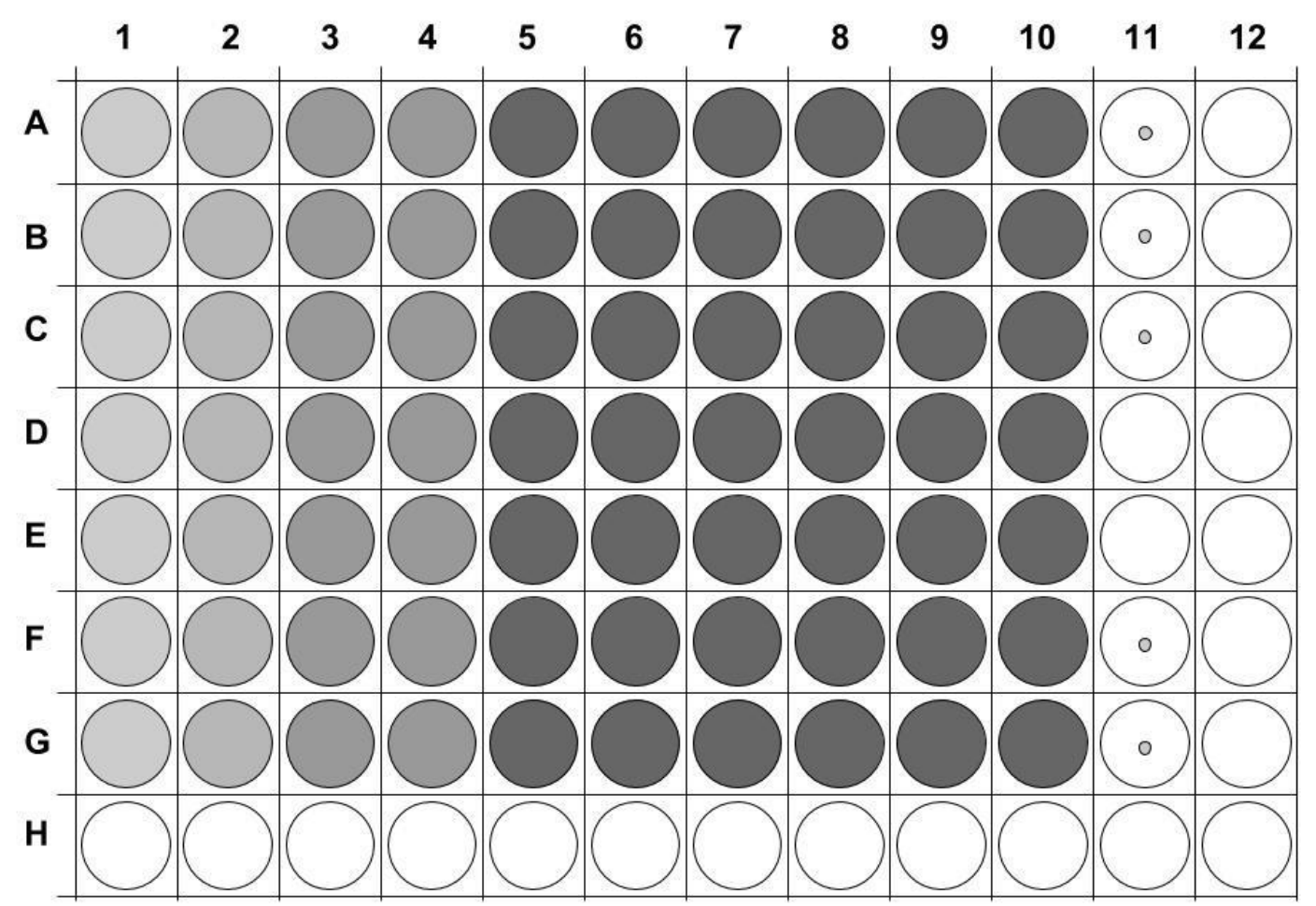

Figure 4.19 Trial 3 MIC with proteolysis with no endpoint

Row A: $0.0 \% \mathrm{NaCl}, \mathrm{pH}=5.2$

Row B: $0.5 \% \mathrm{NaCl}, \mathrm{pH}=5.2$

Row C: $1.0 \% \mathrm{NaCl}, \mathrm{pH}=5.2$

Row D: $2.5 \% \mathrm{NaCl}, \mathrm{pH}=5.2$

Row E: $0.0 \% \mathrm{NaCl}, \mathrm{pH}=4.6$

Row F: $0.0 \% \mathrm{NaCl}, \mathrm{pH}=4.8$

Row G: $0.0 \% \mathrm{NaCl}, \mathrm{pH}=5.0$

Row $\mathrm{H}$ is empty

Protein Concentrations in MHB inoculated with E. coli:

Column 1: $256 \mu \mathrm{g} / \mathrm{mL}$

Column 2: $128 \mu \mathrm{g} / \mathrm{mL}$

Column 3: $64 \mu \mathrm{g} / \mathrm{mL}$

Column 4: $32 \mu \mathrm{g} / \mathrm{mL}$

Column 5: $16 \mu \mathrm{g} / \mathrm{mL}$

Column 6: $8 \mu \mathrm{g} / \mathrm{mL}$

Column 7: $4 \mu \mathrm{g} / \mathrm{mL}$

Column 8: $2 \mu \mathrm{g} / \mathrm{mL}$

Column 9: $1 \mu \mathrm{g} / \mathrm{mL}$

Controls:

Column 10: E. coli and MHB + PBS

Column 11: $256 \mu \mathrm{g} / \mathrm{mL}$ protein solution in MHB/TrypZean

Column 12: MHB and PBS 


\subsubsection{Proteolysis with endpoints}

Two additional plates run with samples from trial 2 were assayed with proteolysis with different endpoints. Crude protein was standardized to $256 \mu \mathrm{g} / \mathrm{mL}$ in a solution of PBS and enzyme solution and then diluted according to procedure. $2.56 \mu \mathrm{L}$ of prepared TrypZean were added to each well of sample and incubated for 2 hours at $37^{\circ} \mathrm{C}$. One set was boiled for $5 \mathrm{~min}$, and one set was incubated at $50^{\circ} \mathrm{C}$ for 5 minutes. After an additional 20 hours of incubation at $37^{\circ} \mathrm{C}$, growth/no growth was observed. Figures 4.20 and 4.21 illustrate the growth patterns.

The plate with 5 minutes of boiling showed no growth in columns 11(except for 11D) or 12. Wells D5 and C3 showed only slight turbidity. Otherwise, there was similar growth throughout.

The plate heated to $50^{\circ} \mathrm{C}$ for 5 minutes showed no growth in column 12 , and no growth in column 11 wells $\mathrm{C}$ and $\mathrm{D}$. Otherwise column 11 showed a slight turbidity. F8 had no growth. Columns 1 and 2 were less turbid than other columns. 


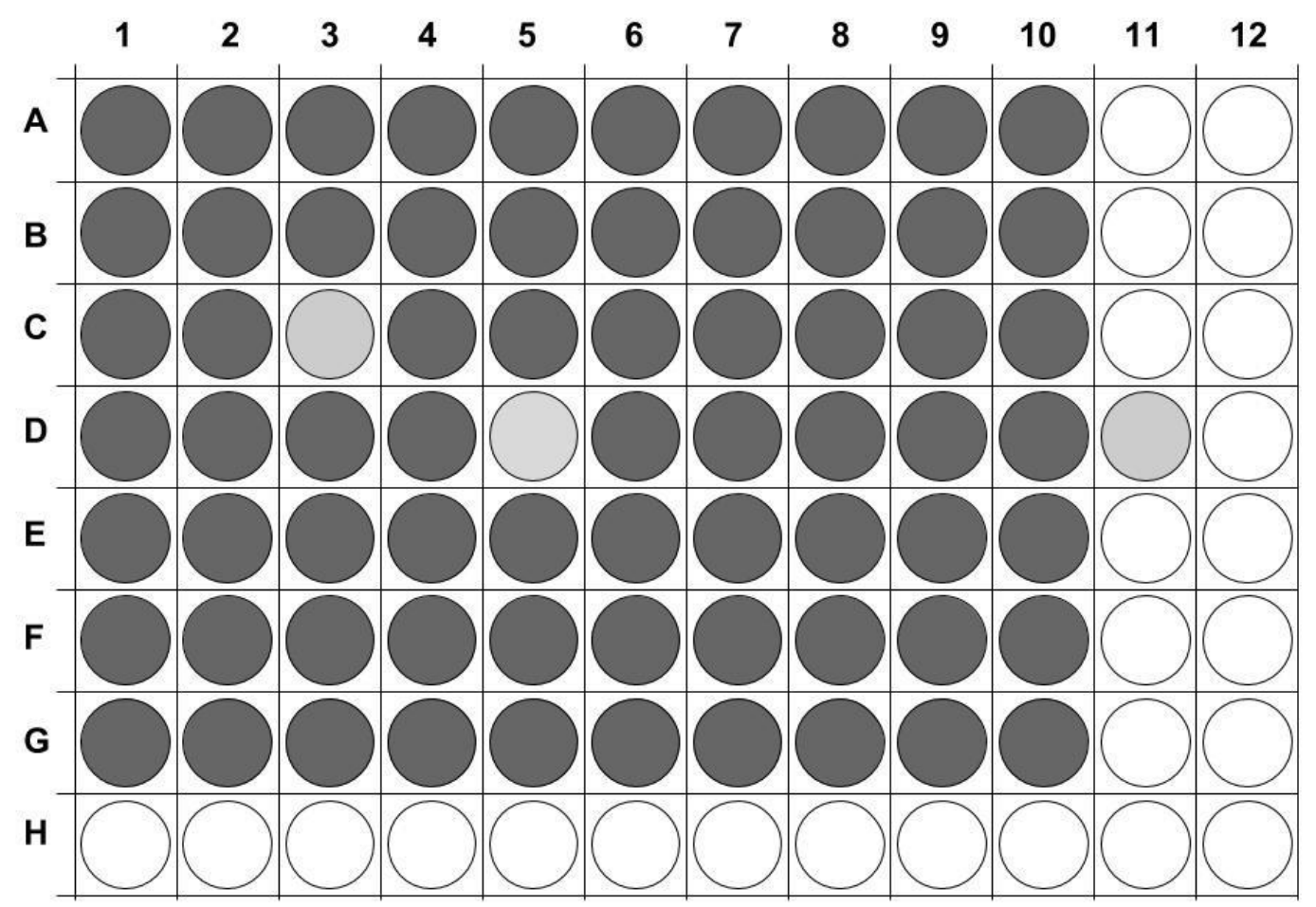

Figure 4.20 Trial 2 MIC with proteolysis with boiling as endpoint

Row A: $0.0 \% \mathrm{NaCl}, \mathrm{pH}=5.2$

Row B: $0.5 \% \mathrm{NaCl}, \mathrm{pH}=5.2$

Row C: $1.0 \% \mathrm{NaCl}, \mathrm{pH}=5.2$

Row D: $2.5 \% \mathrm{NaCl}, \mathrm{pH}=5.2$

Row E: $0.0 \% \mathrm{NaCl}, \mathrm{pH}=4.6$

Row F: $0.0 \% \mathrm{NaCl}, \mathrm{pH}=4.8$

Row G: $0.0 \% \mathrm{NaCl}, \mathrm{pH}=5.0$

Row $\mathrm{H}$ is empty

Protein Concentrations in MHB inoculated with E. coli:

Column 1: $256 \mu \mathrm{g} / \mathrm{mL}$

Column 2: $128 \mu \mathrm{g} / \mathrm{mL}$

Column 3: $64 \mu \mathrm{g} / \mathrm{mL}$

Column 4: $32 \mu \mathrm{g} / \mathrm{mL}$

Column 5: $16 \mu \mathrm{g} / \mathrm{mL}$

Column 6: $8 \mu \mathrm{g} / \mathrm{mL}$

Column 7: $4 \mu \mathrm{g} / \mathrm{mL}$

Column 8: $2 \mu \mathrm{g} / \mathrm{mL}$

Column 9: $1 \mu \mathrm{g} / \mathrm{mL}$

Controls:

Column 10: E. coli and MHB + PBS

Column 11: $256 \mu \mathrm{g} / \mathrm{mL}$ protein solution in MHB/TrypZean

Column 12: MHB and PBS 


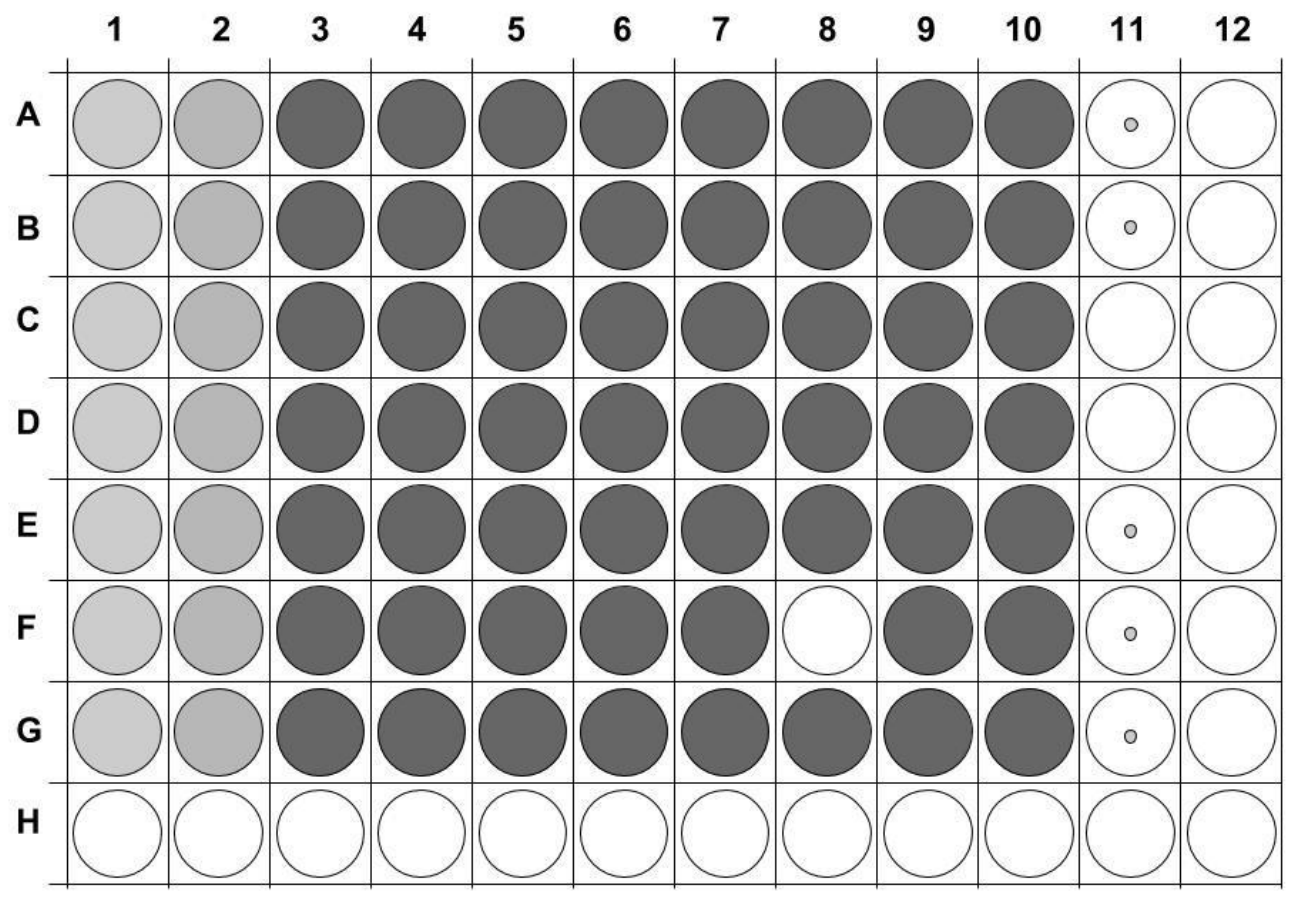

Figure 4.21 Trial $2 \mathrm{MIC}$ with proteolysis heated to $50^{\circ} \mathrm{C}$ as endpoint

Row A: $0.0 \% \mathrm{NaCl}, \mathrm{pH}=5.2$

Row B: $0.5 \% \mathrm{NaCl}, \mathrm{pH}=5.2$

Row C: $1.0 \% \mathrm{NaCl}, \mathrm{pH}=5.2$

Row D: $2.5 \% \mathrm{NaCl}, \mathrm{pH}=5.2$

Row E: $0.0 \% \mathrm{NaCl}, \mathrm{pH}=4.6$

Row F: $0.0 \% \mathrm{NaCl}, \mathrm{pH}=4.8$

Row G: $0.0 \% \mathrm{NaCl}, \mathrm{pH}=5.0$

Row $\mathrm{H}$ is empty

Protein Concentrations in MHB inoculated with E. coli:

Column 1: $256 \mu \mathrm{g} / \mathrm{mL}$

Column 2: $128 \mu \mathrm{g} / \mathrm{mL}$

Column 3: $64 \mu \mathrm{g} / \mathrm{mL}$

Column 4: $32 \mu \mathrm{g} / \mathrm{mL}$

Column 5: $16 \mu \mathrm{g} / \mathrm{mL}$

Column 6: $8 \mu \mathrm{g} / \mathrm{mL}$

Column 7: $4 \mu \mathrm{g} / \mathrm{mL}$

Column 8: $2 \mu \mathrm{g} / \mathrm{mL}$

Column 9: $1 \mu \mathrm{g} / \mathrm{mL}$

Controls:

Column 10: E. coli and MHB + PBS

Column 11: $256 \mu \mathrm{g} / \mathrm{mL}$ protein solution in MHB/TrypZean

Column 12: MHB and PBS 


\section{CHAPTER 5: CONCLUSIONS AND LIMITATIONS}

The main purpose of this thesis was to find a use for an industrial egg yolk by-product from IgY extraction that has previously been treated as waste. This objective included exploring techniques for separating proteins from lipids from the by-product, as well as quantifying and characterizing recovered proteins. Furthermore, it was hypothesized that the protein extract would show anti-microbial properties against $E$. coli.

This study showed that the by product of the $\operatorname{IgY}$ extraction is rich in proteins that have potential uses. The results proved that addition of $\mathrm{NaCl}$ to the yellow cake significantly affected the amount of protein recovered. The greatest amount of protein recovered was demonstrated at the highest $\mathrm{NaCl}$ level tested, $2.5 \%$, suggesting the disassociation of the HDL-phosvitin complexes. The increased amount of salt also increased the variety of proteins recovered. At a level of $2.5 \% \mathrm{NaCl}$, additional unique bands were revealed on the SDS-PAGE gels.

Moreover, as salt addition increased, the water-soluble portion inverted to the bottom layer, forming a lipid pellicle on top. With additional $\mathrm{pH}$ adjustment and centrifugation, a protein pellet formed on the bottom. This is important for an industrial scale separation because it will make collection of the protein fraction from the bottom of a tank a much easier process. At a concentration of $5 \% \mathrm{NaCl}$, the two fractions inverted completely. At $\mathrm{pH}$ of 4 , salt concentration between 3-7\% did not have an effect on the variety of proteins extracted. 
There was no evidence that $\mathrm{pH}$ has an effect on the amount of protein recovered in the range that was tested in this project. It also did not change the variety of proteins that were recovered.

There was no conclusive evidence on the anti-bacterial properties of the crude protein extract against $E$. coli. Although there was no quantifiable evidence from the MIC assay, the results showed an interesting trend. Some of the plates showed increased turbidity across the plates at lower concentrations of the protein extract. This suggests that the crude protein extract may have some bacteriostatic abilities. Some of the individual proteins and peptides in the extract may harbor these properties.

Due to the nature of projects utilizing by-products, it needs to be considered that there are variations in results caused by inconsistencies of the processes upstream. The project was confined to three trial replicates because of limited time and resources, but more trial replicates would help minimize deviations in the data. 


\section{CHAPTER 6: DIRECTIONS FOR FUTURE RESEARCH}

This project provides an opening for further research on how to best utilize byproducts from commercial scale IgY extractions. The separation methods laid out are a practical solution for the food and cosmetic industries for further separation of water soluble fractions because they successfully utilize common equipment and food grade materials. It is therefore pragmatic to continue to explore optimization of byproducts of similar nature. Some ideas for future research include:

- Purification of the peptides in the crude protein extract by means of highly accurate techniques, such as HPLC.

- Expand anti-bacterial study by testing effectiveness of crude protein extract, as well as isolated peptides, against a variety of different bacterial organisms, including gram-positive and gram-negative.

- Broaden study to include effect of different types of salt on protein recovery

- Test for different functionalities of proteins, including antioxidative properties Additionally, there are many opportunities for research containing the lipids present in the by-product. This would include characterizing and isolating the lipids to use for their bioactive and rheologic potential. 


\section{REFERENCES}

Abdou, A.M., M. Kim, and K. Sato. 2013. Functional Proteins and Peptides of Hen's Egg Origin. Bioactive Food Peptides in Health and Disease. 115-136. doi:10.5772/54030.

Abe, Y., T. Itoh, and S. Adachi. 1982. Fractionation and Characterization of Hen's Egg Yolk Phosvitin. Journal of Food Science. 47:1903-1907. doi:10.1111/j.1365-2621.1982.tb12910.x.

Akita, E.M., and S. Nakai. 1992. Immunoglobulins from Egg Yolk: Isolation and Purification. Journal of Food Science. 57:629-634. doi:10.1111/j.13652621.1992.tb08058.x.

Akita, E., and S. Nakai. 1993. Comparison of four purification methods for the production of immunoglobulins from eggs laid by hens immunized with an enterotoxigenic E. coli strain. Journal of Immunological Methods. 160:207214. doi:10.1016/0022-1759(93)90179-b.

American Egg Board. Industry Overview - American Egg Board.

Anton, M., and G. Gandemer. 1997. Composition, Solubility and Emulsifying Properties of Granules and Plasma of Egg Yolk. Journal of Food Science. 62:484-487. doi:10.1111/j.1365-2621.1997.tb04411.x.

Anton, M., M.L. Denmat, and G. Gandemer. 2000. Thermostability of Hen Egg Yolk Granules: Contribution of Native Structure of Granules. Journal of Food Science. 65:581-584. doi:10.1111/j.1365-2621.2000.tb16052.x.

Anton, M., F. Nau, and Y. Nys. 2006. Bioactive egg components and their potential uses. World's Poultry Science Journal. 62:429-438. doi:10.1079/wps2005105. 
Anton, M. 2013. Egg yolk: structures, functionalities and processes. Journal of the Science of Food and Agriculture. 93:2871-2880. doi:10.1002/jsfa.6247.

Awade, A.C. 1996. On hen egg fractionation: applications of liquid chromatography to the isolation and the purification of hen egg white and egg yolk proteins. Zeitschrift $\gg r$ Lebensmittel-Untersuchung und-Forschung. 202:1-14. doi:10.1007/bf01229676.

Barrenetxe, J., P. Aranguren, A. Grijalba, J. Martínez-Peñuela, F. Marzo, and E. Urdaneta. 2006. Effect of dietary quercetin and sphingomyelin on intestinal nutrient absorption and animal growth. British Journal of Nutrition. 95:455461. doi:10.1079/bjn20051651.

Brady, D., S. Gaines, L. Fenelon, J. Mcpartlin, and C. O'farrelly. 2002. A Lipoprotein-derived Antimicrobial Factor from Hen-egg Yolk is Active Against Streptococcus Species. Journal of Food Science. 67:3096-3103. doi:10.1111/j.1365-2621.2002.tb08865.x.

Causeret, D., E. Matringe, and D. Lorient. 1991. Ionic Strength and pH Effects on Composition and Microstructure of Yolk Granules. Journal of Food Science. 56:1532-1536. doi:10.1111/j.1365-2621.1991.tb08634.x.

Coutinho, H.D.M., K.M. Lobo, D.A.C. Bezerra, and I. Lobo. 2008. Peptides and proteins with antimicrobial activity. Indian Journal of Pharmacology. doi:10.4103/0253-7613.40481.

Denmat, M., M. Anton, and G. Gandemer. 1999. Protein Denaturation and Emulsifying Properties of Plasma and Granules of Egg Yolk as Related to Heat Treatment. Journal of Food Science. 64:194-197. doi:10.1111/j.1365- 
2621.1999.tb15863.x.

Eckert, E., A. Zambrowicz, M. Pokora, B. Setner, A. Dąbrowska, M. Szołtysik, Z. Szewczuk, A. Polanowski, T. Trziszka, and J. Chrzanowska. 2014. Egg-yolk protein by-product as a source of ACE-inhibitory peptides obtained with using unconventional proteinase from Asian pumpkin (Cucurbita ficifolia). Journal of Proteomics. 110:107-116. doi:10.1016/j.jprot.2014.08.003.

Hasiak, R.J., D.V. Vadehra, R.C. Baker, and L. Hood. 1972. Effect Of Certain Physical And Chemical Treatments On The Microstructure Of Egg Yolk. Journal of Food Science. 37:913-917. doi:10.1111/j.13652621.1972.tb03702.x.

Hodek, P., P. Trefil, J. Simunek, J. Hudecek, and M. Stiborova. 2013. Optimized protocol of chicken antibody (IgY) purification providing electrophoretically homogeneous preparations. Int. J. Electrochem. Sci. 8:113-124.

Immunity Types. 2017. Centers for Disease Control and Prevention.

Itoh, T., M. Kubo, and S. Adachi. 1986. Isolation and Characterization of Major Apoproteins from Hen's Egg Yolk Granule. Journal of Food Science. 51:1115-1117. doi:10.1111/j.1365-2621.1986.tb13061.x.

Jolivet, P., C. Boulard, V. Beaumal, T. Chardot, and M. Anton. 2006. Protein Components of Low-Density Lipoproteins Purified from Hen Egg Yolk. Journal of Agricultural and Food Chemistry. 54:4424-4429. doi:10.1021/jf0531398.

Karlsson, M., H. Kollberg, and A. Larsson. 2004. Chicken IgY: utilizing the evolutionary advantage. World's Poultry Science Journal. 60:341-348. 
doi:10.1079/wps200422.

Ko, K.Y., K.C. Nam, C. Jo, E.J. Lee, and D.U. Ahn. 2012. Erratum to "A simple and efficient method for preparing partially purified phosvitin from egg yolk using ethanol and salts" (Poult. Sci. 90(5):1096-1104). Poultry Science. 91:1496-1496. doi:10.3382/ps.2012-91-6-1496.

Küllenberg, D., L.A. Taylor, M. Schneider, and U. Massing. 2012. Health effects of dietary phospholipids. Lipids in Health and Disease. 11. doi:10.1186/1476$511 x-11-3$

Li, X., L. Wang, Y. Zhen, S. Li, and Y. Xu. 2015. Chicken egg yolk antibodies (IgY) as non-antibiotic production enhancers for use in swine production: a review. Journal of Animal Science and Biotechnology. 6:40. doi:10.1186/s40104015-0038-8.

Mann, K., and M. Mann. 2008. The chicken egg yolk plasma and granule proteomes. Proteomics. 8:178-191. doi:10.1002/pmic.200700790.

Marcet, I., B. Paredes, and M. Díaz. 2015. Egg yolk granules as low-cholesterol replacer of whole egg yolk in the preparation of gluten-free muffins. $L W T$ Food Science and Technology. 62:613-619. doi:10.1016/j.lwt.2014.08.031.

Marcq, C., A. Thewis, D. Portelle, and Y. Beckers. 2013. Refinement of the production of antigen-specific hen egg yolk antibodies (IgY) intended for passive dietary immunization in animals. Biotechnologie, Agronomie, Société Et Environnement. 17(3):483-493.

Milinsk, M., A. Murakami, S. Gomes, M. Matsushita, and N. de Souza. 2003. Fatty acid profile of egg yolk lipids from hens fed diets rich in n-3 fatty acids. 
Food Chemistry. 83:287-292. doi:10.1016/s0308-8146(03)00094-3.

Mine, Y., and J. Kovacs-Nolan. 2006. New insights in biologically active proteins and peptides derived from hen egg. World's Poultry Science Journal. 62:8796. doi:10.1079/wps200586.

Mine, Y., C. Oberle, and Z. Kassaify. 2003. Eggshell Matrix Proteins as Defense Mechanism of Avian Eggs. Journal of Agricultural and Food Chemistry. 51:249-253. doi:10.1021/jf020597x.

Mine, Y., F. Ma, and S. Lauriau. 2004. Antimicrobial Peptides Released by Enzymatic Hydrolysis of Hen Egg White Lysozyme. Journal of Agricultural and Food Chemistry. 52:1088-1094. doi:10.1021/jf0345752.

Mine, Y. 2008. Egg bioscience and biotechnology. Wiley-Interscience, Hoboken, NJ. Nilsson, E., J. Stålberg, and A. Larsson. 2012. IgY stability in eggs stored at room temperature or at $4^{\circ} \mathrm{C}$. British Poultry Science. 53:42-46. doi:10.1080/00071668.2011.646951.

Nilsson, E., Hanrieder Jörg, J. Bergquist, and A. Larsson. 2008. Proteomic Characterization of IgY Preparations Purified with a Water Dilution Method. Journal of Agricultural and Food Chemistry. 56:11638-11642. doi:10.1021/jf802626t.

Park, P.-J., W.-K. Jung, K.-S. Nam, F. Shahidi, and S.-K. Kim. 2001. Purification and characterization of antioxidative peptides from protein hydrolysate of lecithin-free egg yolk. Journal of the American Oil Chemists' Society. 78:651-656. doi:10.1007/s11746-001-0321-0.

Position of the American Dietetic Association: Functional Foods. 2004. Journal of 
the American Dietetic Association. 104:814-826.

doi:10.1016/j.jada.2004.03.015.

Purdue University. Purdue Food Animal Education Network.

Samaraweera, H., W.-G. Zhang, E.J. Lee, and D.U. Ahn. 2011. Egg Yolk Phosvitin and Functional Phosphopeptides-Review. Journal of Food Science. 76:R143R150. doi:10.1111/j.1750-3841.2011.02291.x.

Schmidt, L.D., G. Blank, D. Boros, and B.A. Slominski. 2007. The nutritive value of egg by-products and their potential bactericidal activity:in vitro andin vivo studies. Journal of the Science of Food and Agriculture. 87:378-387. doi:10.1002/jsfa.2685.

Sirvente, H., V. Beaumal, C. Gaillard, L. Bialek, D. Hamm, and M. Anton. 2007. Structuring and Functionalization of Dispersions Containing Egg Yolk, Plasma and Granules Induced by Mechanical Treatments. Journal of Agricultural and Food Chemistry. 55:9537-9544. doi:10.1021/jf0719398.

Slotte, P.J., and B. Ramstedt. 2007. The functional role of sphingomyelin in cell membranes. European Journal of Lipid Science and Technology. 109:977981. doi:10.1002/ejlt.200700024.

Song, W.O., and J.M. Kerver. 2013. Nutritional Contribution of Eggs to American Diets. Journal of the American College of Nutrition. 19:556S-562S. doi:10.1080/07315724.2000.10718980.

Strixner, T., and U. Kulozik. 2013. Continuous centrifugal fractionation of egg yolk granules and plasma constituents influenced by process conditions and product characteristics. Journal of Food Engineering. 117:89-98. 
doi:10.1016/j.jfoodeng.2013.02.009.

United States Department of Agriculture. 2000. Egg Grading Manual. Agricultural Marketing Service.

Walther, B., and R. Sieber. 2011. Bioactive proteins and peptides in foods. Int J Vitam Nutr Res. 8(2-3):181-192. doi:10.1024/0300-9831/a000054.

Wiegand, I., K. Hilpert, and R.E.W. Hancock. 2008. Agar and broth dilution methods to determine the minimal inhibitory concentration (MIC) of antimicrobial substances. Nature Protocols. 3:163-175. doi:10.1038/nprot.2007.521.

Xu, X., S. Katayama, and Y. Mine. 2007. Antioxidant activity of tryptic digests of hen egg yolk phosvitin. Journal of the Science of Food and Agriculture. 87:2604-2608. doi:10.1002/jsfa.3015.

Zabłocka, A., A. Sosnowska, A. Urbaniak, M. Janusz, and A. Polanowski. 2014. Peptides accompanying chicken egg yolk IgY - alternative methods of isolation and immunoregulatory activity. Food \&amp; Function. 5:724-733. doi:10.1039/c3fo60391a.

Zambrowicz, A., M. Pokora, E. Eckert, M. Szoltysik, A. Dabrowska, J. Chrzanowska, and T. Trziszka. 2012. Antioxidant and antimicrobial activity of lecithin free egg yolk protein preparation hydrolysates obtained with digestive enzymes. Functional Foods in Health and Disease. 2(12):487-500.

Zambrowicz, A., A. Dąbrowska, Ł. Bobak, and M. Szołtysik. 2014. Egg yolk proteins and peptides with biological activity. Postępy Higieny i Medycyny Doświadczalnej. 68:1524-1529. doi:10.5604/17322693.1133600.

Zambrowicz, A., M. Pokora, B. Setner, A. Dąbrowska, M. Szołtysik, K. Babij, Z. 
Szewczuk, T. Trziszka, G. Lubec, and J. Chrzanowska. 2014. Multifunctional peptides derived from an egg yolk protein hydrolysate: isolation and characterization. Amino Acids. 47:369-380. doi:10.1007/s00726-014-1869-x. 


\section{APPENDICES}

Appendix A: BCA output

1. Standard Curve

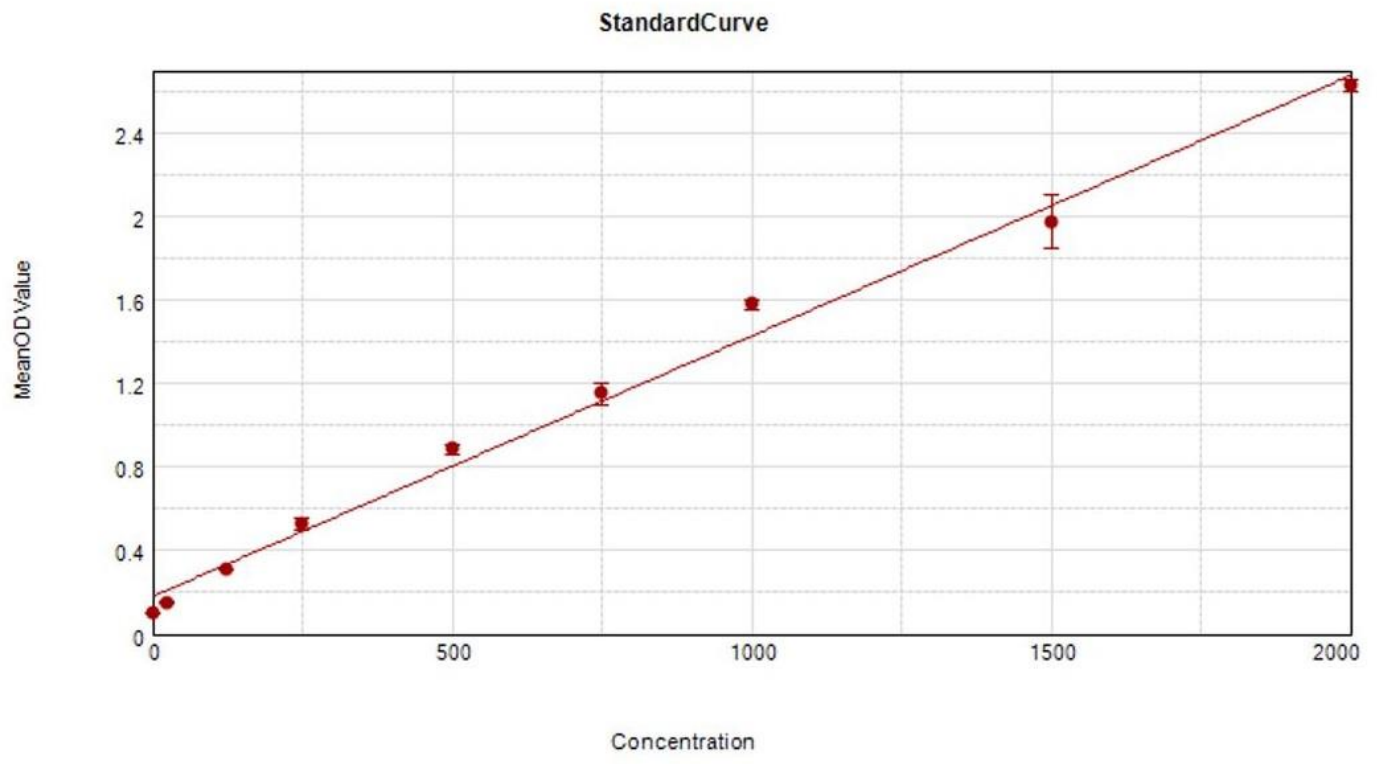




\section{BCA output}

Unknowns

\begin{tabular}{|c|c|c|c|c|c|c|c|}
\hline Sample & Wells & OD_Values & $\mathrm{R}$ & Concentration & MeanConc & SD & $\mathrm{CV}$ \\
\hline 02 & E12 & 0.137 & & -35.798 & -35.798 & 0.000 & 0.0 \\
\hline \multirow[t]{3}{*}{04} & G10 & 0.146 & \multirow{3}{*}{$\mathrm{R}$} & -27.867 & \multirow[t]{3}{*}{-43.810} & \multirow[t]{3}{*}{19.649} & \multirow[t]{3}{*}{44.9} \\
\hline & G11 & 0.099 & & -65.762 & & & \\
\hline & G12 & 0.134 & & -37.801 & & & \\
\hline \multirow[t]{2}{*}{ T1.1 } & $\mathrm{C} 1$ & 1.059 & & 702.957 & \multirow[t]{2}{*}{692.342} & \multirow[t]{2}{*}{15.013} & \multirow[t]{2}{*}{2.2} \\
\hline & $\mathrm{CB}$ & 1.032 & & 681.727 & & & \\
\hline \multirow[t]{2}{*}{ T1.2 } & $\mathrm{C} 2$ & 1.126 & & 756.876 & \multirow[t]{2}{*}{776.665} & \multirow[t]{2}{*}{27.986} & \multirow[t]{2}{*}{3.6} \\
\hline & $\mathrm{Cg}$ & 1.175 & & 796.454 & & & \\
\hline \multirow[t]{2}{*}{ T1.3 } & C3 & 0.808 & & 502.506 & \multirow[t]{2}{*}{532.149} & \multirow[t]{2}{*}{41.922} & \multirow[t]{2}{*}{7.5} \\
\hline & $\mathrm{C} 10$ & 0.882 & & 561.792 & & & \\
\hline \multirow[t]{2}{*}{ T1.4 } & $\mathrm{C} 4$ & 1.367 & & 950.358 & \multirow[t]{2}{*}{985.529} & \multirow[t]{2}{*}{49.740} & \multirow[t]{2}{*}{5.0} \\
\hline & C11 & 1.455 & & 1020.700 & & & \\
\hline \multirow[t]{2}{*}{ T1.5 } & $\mathrm{C} 5$ & 1.035 & & 683.970 & 730.077 & 65.205 & 8.9 \\
\hline & $\mathrm{C} 12$ & 1.150 & & 776.184 & & & \\
\hline T1.6 & C6 & 1.010 & & 664.101 & 691.541 & 38.806 & 5.6 \\
\hline & D8 & 1.079 & & 718.981 & & & \\
\hline $\mathrm{T} 1.7$ & C7 & 1.703 & & 1218.909 & 1265.897 & 66.452 & 5.2 \\
\hline & $\mathrm{D} 9$ & 1.820 & & 1312.886 & & & \\
\hline $\mathrm{T} 2.1$ & D10 & 1.023 & & 674.115 & 669.349 & 6.741 & 1.0 \\
\hline & E1 & 1.011 & & 664.582 & & & \\
\hline $\mathrm{T} 2.2$ & D11 & 1.136 & & 764.808 & 763.005 & 2.549 & 0.3 \\
\hline & E2 & 1.131 & & 761.202 & & & \\
\hline $\mathrm{T} 2.3$ & D12 & 0.696 & & 412.695 & 388.940 & 33.594 & 8.6 \\
\hline & E3 & 0.637 & & 365.186 & & & \\
\hline $\mathrm{T} 2.4$ & $\mathrm{E} 4$ & 3.981 & $\mathrm{R}$ & 3044.448 & 3051.979 & 10.650 & 0.3 \\
\hline & E8 & 4.000 & $\mathrm{R}$ & 3059.510 & & & \\
\hline $\mathrm{T} 2.5$ & E5 & 0.550 & & 295.324 & 306.380 & 15.636 & 5.1 \\
\hline & E9 & 0.577 & & 317.436 & & & \\
\hline T2.6 & E6 & 0.873 & & 554.341 & 537.597 & 23.680 & 4.4 \\
\hline & E10 & 0.831 & & 520.852 & & & \\
\hline $\mathrm{T} 2.7$ & E7 & 0.454 & & 218.412 & 221.376 & 4.192 & 1.9 \\
\hline & E11 & 0.461 & & 224.340 & & & \\
\hline $\mathrm{T} 3.1$ & $\mathrm{~F} 8$ & 0.544 & & 290.917 & 283.867 & 9.971 & 3.5 \\
\hline & G1 & 0.527 & & 276.817 & & & \\
\hline $\mathrm{T} 3.2$ & F9 & 0.857 & & 541.442 & 518.889 & 31.895 & 6.1 \\
\hline & $\mathrm{G} 2$ & 0.801 & & 496.337 & & & \\
\hline T3.3 & F10 & 0.698 & & 414.377 & 401.438 & 18.298 & 4.6 \\
\hline & G3 & 0.666 & & 388.499 & & & \\
\hline T3.4 & F11 & 2.106 & & 1542.100 & 1468.352 & 104.295 & 7.1 \\
\hline & G4 & 1.922 & & 1394.605 & & & \\
\hline T3.5 & F12 & 0.718 & & 429.840 & 429.840 & 0.000 & 0.0 \\
\hline & G5 & 0.718 & & 429.840 & & & \\
\hline T3.6 & G6 & 0.522 & & 272.811 & 281.584 & 12.407 & 4.4 \\
\hline & G8 & 0.544 & & 290.357 & & & \\
\hline T3.7 & G7 & 0.522 & & 273.131 & 284.148 & 15.579 & 5.5 \\
\hline & G9 & 0.550 & & 295.164 & & & \\
\hline
\end{tabular}


Appendix B: BCA raw data table

\begin{tabular}{|c|c|c|c|}
\hline Trial number & Salt Conc \% & pH & Avg Protein Conc in ug/ml \\
\hline 1 & 0 & 5.2 & 692 \\
\hline 1 & 0.5 & 5.2 & 776 \\
\hline 1 & 1 & 5.2 & 532 \\
\hline 1 & $2.50 \%$ & 5.2 & 985 \\
\hline 1 & 0 & 4.6 & 730 \\
\hline 1 & 0 & 4.8 & 691 \\
\hline 1 & 0 & 5 & 1265 \\
\hline 2 & 0 & 5.2 & 669 \\
\hline 2 & 0.5 & 5.2 & 763 \\
\hline 2 & 1 & 5.2 & 388 \\
\hline 2 & $2.50 \%$ & 5.2 & 3051 \\
\hline 2 & 0 & 4.6 & 306 \\
\hline 2 & 0 & 4.8 & 537 \\
\hline 2 & 0 & 5 & 221 \\
\hline 3 & 0 & 5.2 & 283 \\
\hline 3 & 0.5 & 5.2 & 518 \\
\hline 3 & 1 & 5.2 & 401 \\
\hline 3 & $2.50 \%$ & 5.2 & 1468 \\
\hline 3 & 0 & 4.6 & 429 \\
\hline 3 & 0 & 4.8 & 281 \\
\hline 3 & 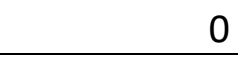 & 5 & 284 \\
\hline
\end{tabular}


Appendix C: JMP output for $\mathrm{NaCl}$ study

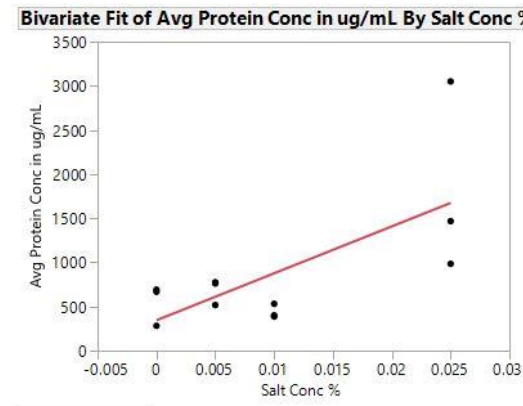

$$
\text { L Linear Fit }
$$

Linear Fit

Avg Protein Conc in ug $/ \mathrm{mL}=345.40476+53176.19 *$ Salt Conc \%

Summary of Fit

RSquare

RSquare Adj $\quad 0.474725$

0.422197
573.1713

Mean of Response $\quad 877.1667$

Analysis of Variance

\begin{tabular}{|l|r|r|r|r|}
\hline Source & DF & $\begin{array}{r}\text { Sum of } \\
\text { Squares }\end{array}$ & Mean Square & F Ratio \\
\hline Model & 1 & 2969092.6 & 2969093 & 9.0376 \\
\hline Error & 10 & 3285253.1 & 328525 & $\begin{array}{l}\text { Prob }>\text { F } \\
\text { C. Total }\end{array}$ \\
11 & 6254345.7 & & $0.0132^{\star}$
\end{tabular}

Parameter Estimates

Term Estimate Std Error t Ratio Prob $>|t|$

$\begin{array}{lllll}\text { Intercept } & 345.40476 & 242.2091 & 1.43 & 0.1843\end{array}$

$\begin{array}{lrrrr}\text { Salt Conc \% } & 53176.19 & 17688.45 & 3.01 & 0.0132^{*}\end{array}$

Diagnostics Plots

Residual by Predicted Plot

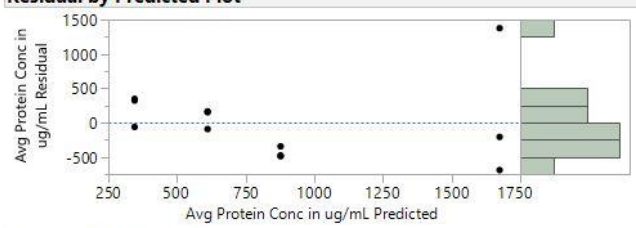

Actual by Predicted Plot
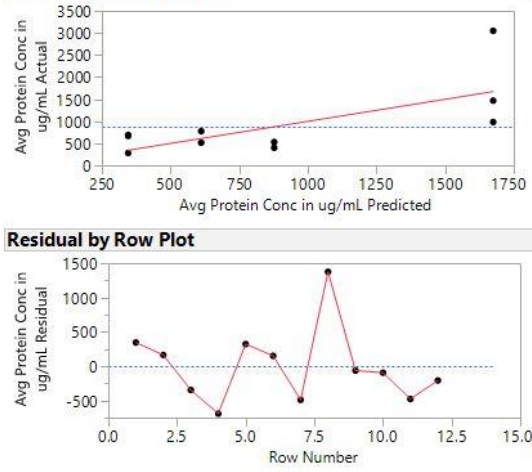

Residual by X Plot
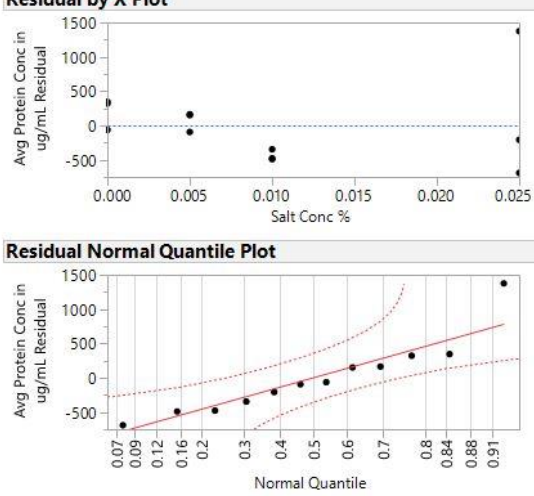
Appendix D: JMP output for $\mathrm{pH}$ study
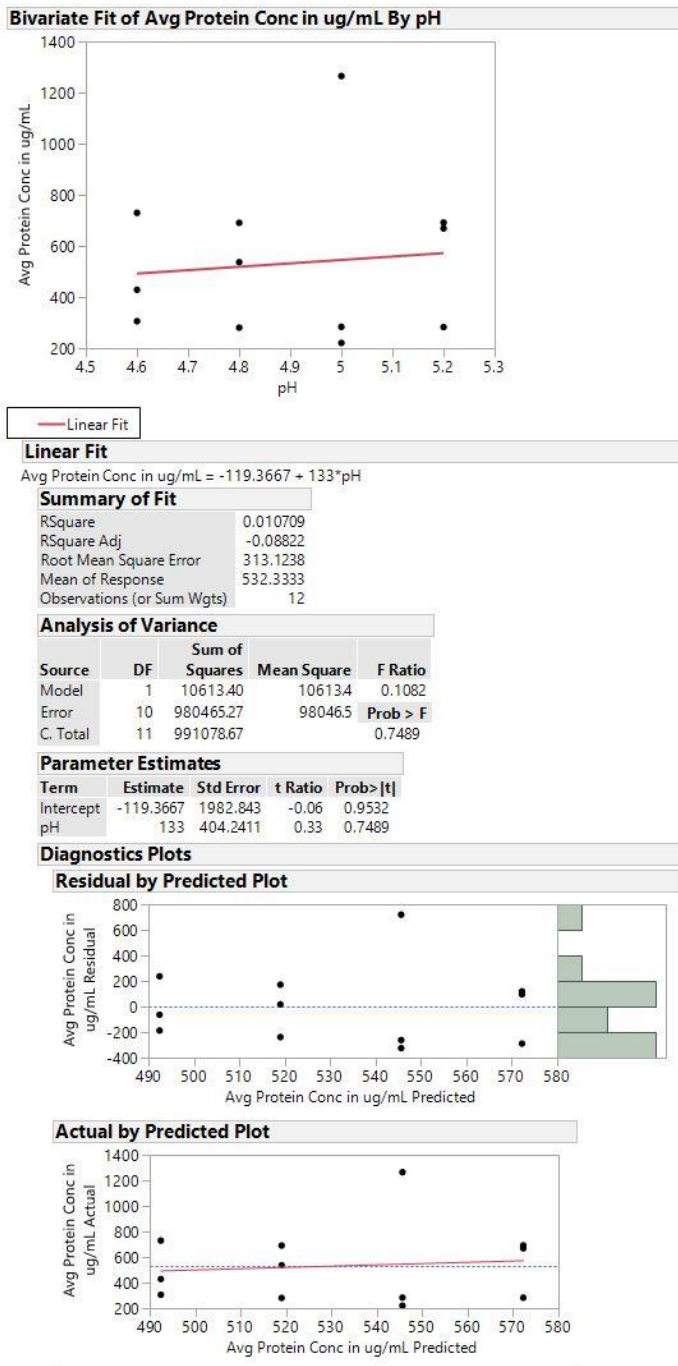

Residual by Row Plot
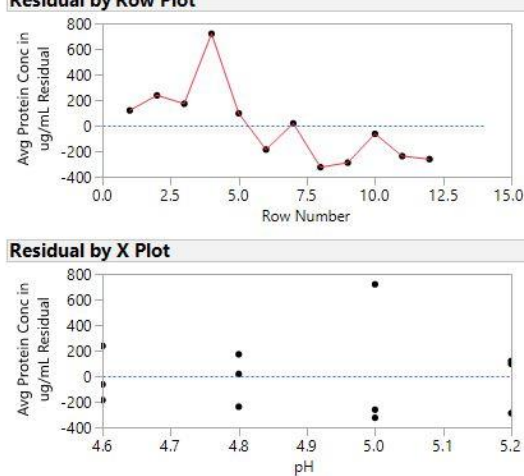

Residual Normal Quantile Plot

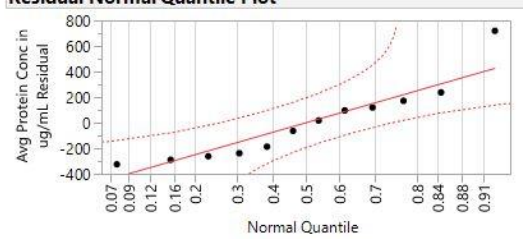

